\title{
CARACTERIZAÇÃO SÓCIO-AMBIENTAL E TECNOLÓGICA DA PRODUÇÃO DE CARVÃO VEGETAL NO MUNICÍPIO DE PEDRA BELA, ESTADO DE SÃO PAULO
}

\author{
ANA MARIA DE MEIRA \\ Engenheira Florestal \\ Orientador: Prof. Dr. JOSÉ OTÁVIO BRITO
}

Dissertação apresentada à Escola Superior de Agricultura "Luiz de Queiroz", Universidade de São Paulo, para obtenção do título de Mestre em Recursos Florestais, com opção em Tecnologia de Produtos Florestais.

PIRACICABA

Estado de São Paulo - Brasil

Agosto - 2002 


\title{
Dados Internacionais de Catalogação na Publicação (CIP)
} DIVISÃo dE BIBLIOTECA E DOCUMENTAÇÃO - ESALQ/USP

\author{
Meira, Ana Maria \\ Caracterizaçăo sócio-ambiental e tecnológica da produçăo de carvăo vegetal no \\ município de Pedra Bela, Estado de Săo Paulo. - - Piracicaba, 2002. \\ $99 \mathrm{p}$. \\ Dissertaçăo (mestrado) - - Escola Superior de Agricultura Luiz de Queiroz, 2002. \\ Bibliografia.
} I. Título

1. Aspectos sociais 2. Carvъo vegetal 3. Impactos ambientais 4 . Tecnologia agrícola

CDD 662.74

Permitida a copia total ou parcial deste documento, desde que citada a fonte- O autor: 


\section{DEDICATÓRIA}

À Deus por todas as oportunidades.

"Quem nada conhece, nada ama. Quem nada pode fazer, nada compreende. Quem nada compreende, nada vale. Mas quem compreende também ama, observa, vê... Quanto mais conhecimento houver inerente numa coisa, tanto maior o amor... Aquele que imagina que todos os frutos amadurecem ao mesmo tempo, como as cerejas, nada sabe a respeito das uvas".

(Paracelso) 


\section{Em berço esplêndido}

Desde o ventre de minha mãe sentia uma quentura longe de ser natural, mas que era rotineira.

Logo que nasci senti o cheiro da fumaça e fuligem, eu queria brisa...

Tão logo fui crescendo já fui aprendendo, a domir num colchão que não era de espuma, nem de pluma, era cinzento...

Os seios de minha mãe cheiravam à cinzas, à defumado.

Meu pai ainda jovem, rosto enrugado...

Queria brincar, deram-me um tiço, um pedaço de carvão e com eles formei quebracabeças.

Meus castelos não eram de areia, mas de cinzas .

Quanto mais crescia, mais meu pai dizia, vai aprendendo menino, esta é a profissão de quem não tem espaço, nem tem outros laços, mas só tem obrigação... escola é só para o filho do patrão.

(Ana Maria) 


\section{AGRADECIMENTOS}

Aos meus pais Geraldo e Ângela, por me ensinarem o valor do afeto e do bom humor.

Aos meus irmãos Adriana, Geraldo, Giliarde e Júlio pelo sorriso e carinho de sempre.

Ao meu orientador Prof. José O. Brito pela atenção, carisma e vivacidade sempre motivadoras e cativantes.

Ao Prof. Caron pelas contribuições sempre pertinentes.

Aos meus amigos Silvia, Elvis (meu revisor), Vera, Ana Paula, Gláucia, Marco Antonio, Vanderlei, Antonio, Alexandre, Michele, Noemi e ao José Fernando próximos ou distantes são preciosos para mim.

Aos carvoeiros de Pedra Bela que, gentilmente, me atenderam em suas propriedades.

Aos companheiros de trabalho e aos estagiários do USP Recicla: Alex, Diego, Janaína, Carol, Lúcio, Samantha, Roth, Claudinéia, Elisa, Elisângela, Lidia, Ana, Raquel, Guilherme, Tânia, Oriza, Beth, Regina, Marcos, Marlus, Vitor, Daniela e Pazu que me proporcionam companheirismo e aprendizagem constantes.

Aos meus amigos do LQCE: Anne, Camilinha, Camila, Regina, Willian, em especial ao Udmilson e a Talita que muito contribuíram para o presente trabalho. 


\section{SUMÁRIO}

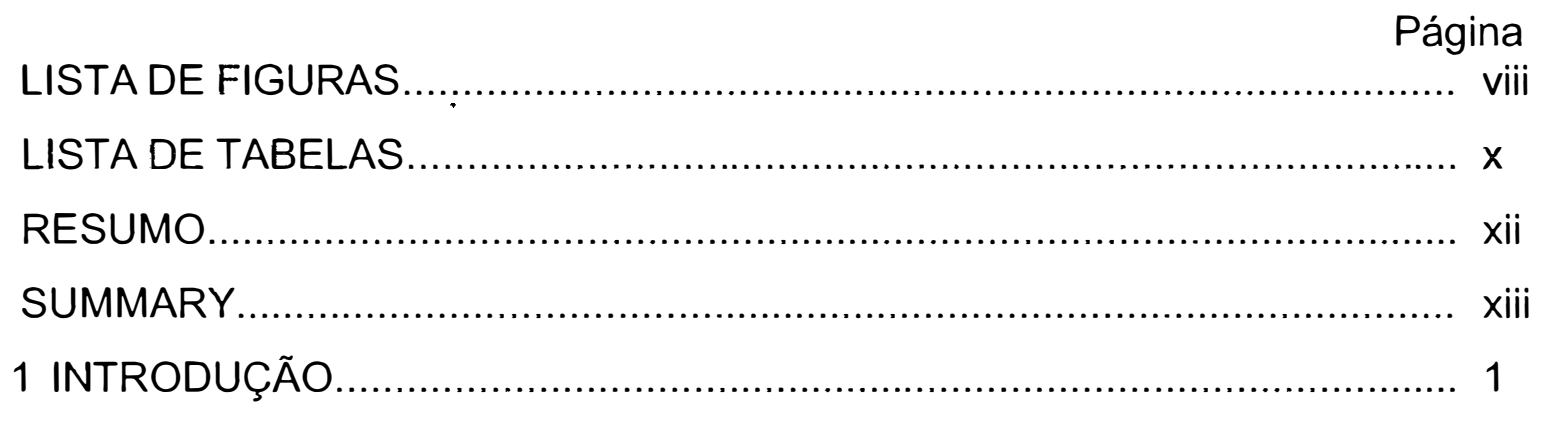

1.1 Motivações para a Realização do Estudo................................................. 2

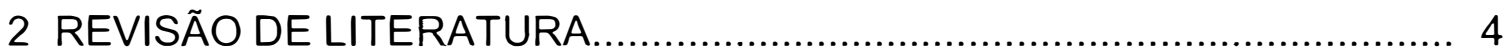

2.1 Aspectos Gerais da Produção e Consumo de Carvão Vegetal.................. 4

2.2 Aspectos Sócio-Ambientais da Produção de Carvão Vegetal no Brasil... 7

2.3 Qualidade do Carvão Vegetal.......................................................... 10

2.4 O Município de Pedra Bela................................................................... 13

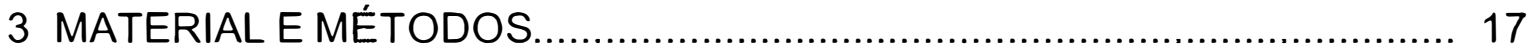

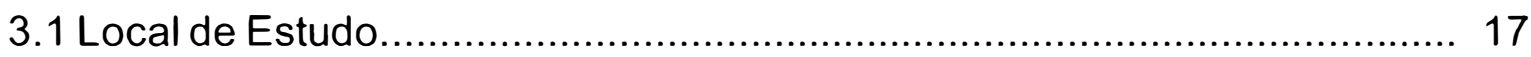

3.2 Amostragem dos Empreendimentos................................................ 18

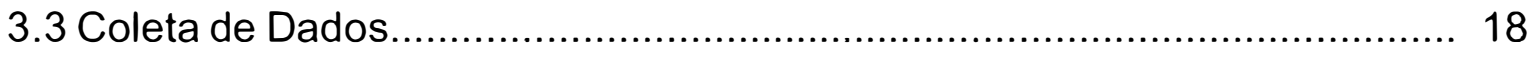

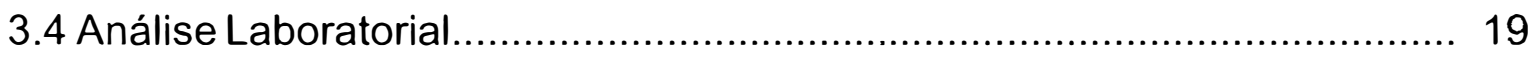

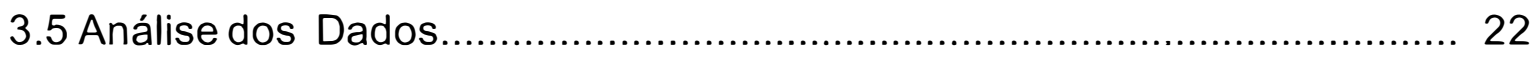

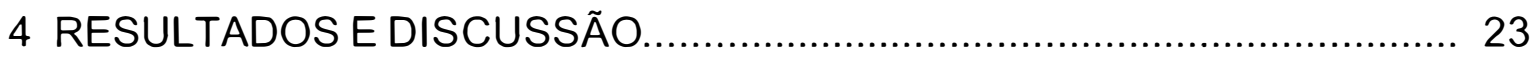

4.1 Resultados Sobre a Produção do Carvão Vegetal.................................. 23

4.2 Aspectos Sócio-Econômicos.............................................................. 45

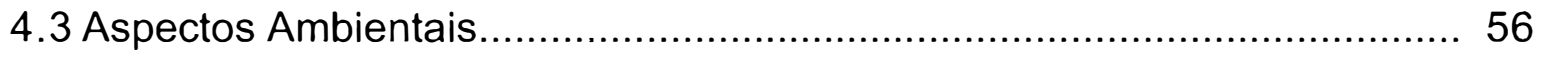

4.4 Parâmetros de Qualidade do Carvão Vegetal.......................................... 61 


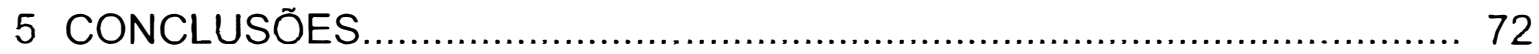

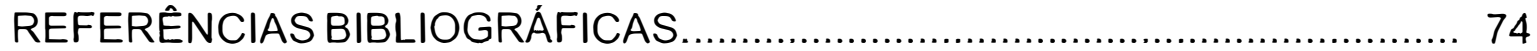

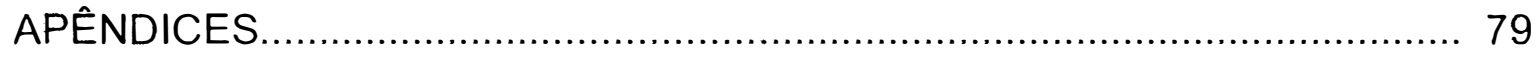




\section{LISTA DE FIGURAS}

Página

1 Consumo de carvão vegetal em São Paulo e em Minas Gerais

2 Distribuição percentual das unidades de produção agrícola (UPAS), por tamanho, no Município de Pedra Bela, Estado de São Paulo, 1995/96............ 14

3 Área cultivada, Município de Pedra Bel/SP, 1995/96 ................................... 15

4 Localização do Município de Pedra Bela/SP .................................................. 17

5 Tipo de atividade desenvolvida nos empreendimentos................................ 24

6 Número de fornos nos empreendimentos de carvão vegetal......................... 26

7 Número de empreendimentos por capacidade de produção de carvão, em

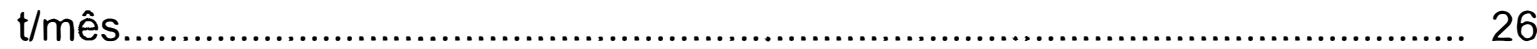

8 Exemplo comum de carvoaria existente em Pedra Bela.............................. 29

9 Exemplo de fornos construídos em barrancos......................................... 30

10 Percentual de empreendimentos que possuem CNPJ e IBAMA .................... 32

11 Origem da matéria-prima utilizada nos empreendimentos............................. 34

12 Tipo de embalagem utilizada para o carvão vegetal................................... 37

13 Exemplo de armazenamento do carvão vegetal no Município de Pedra Bela.. 38

14 Exemplo de embalagem em saco de ráfia e armazenamento à céu aberto.... 38

15 Equipamentos das propriedades ligadas à atividade de carvão vegetal....... 40

16 Infra-estrutura existente nas propriedades................................................ 41

17 Utilização de equipamento de proteção individual nas propriedades................ 43

18 Exemplo das condições de trabalho nas pequenas propriedades de produção de carvão vegetal do Município de Pedra Bela - SP....................... 43 
19 Exemplo de fornos localizados próximos às residências.............................. 49

20 Escolaridade dos trabalhadores da atividade de carvão vegetal de Pedra

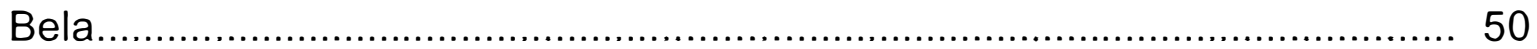

21 Trajeto do carvão vegetal produzido no Município de Pedra Bela/SP ............ 53

22 Incidência dos principais impactos ambientais advindos do carvoejamento,

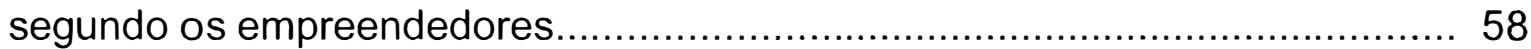

23 Impactos da poluição do ar numa carvoaria típica do Município de Pedra

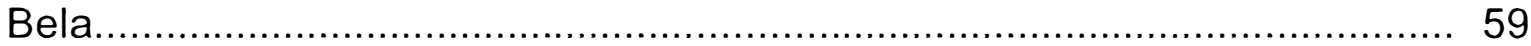

24 Finos de carvão vegetal das propriedades de Pedra Bela............................ 60

25 Fatores considerados importantes para a qualidade do carvão vegetal....... 66

26 Friabilidade do carvão vegetal produzido em Pedra Bela...............................6.67 


\section{LISTA DE TABELA}

Página

1 Origem da matéria-prima para a produção de carvão vegetal, no Brasil... 5

2 Indicações de parâmetros para qualidade do carvão vegetal..................... 13

3 Distribuição das áreas nas unidades de produção agrícola (UPAS), do municipio de Pedra Bela - SP............................................................. 14

4 Classificação do carvão vegetal quanto a sua friabilidade......................... 20

5 Dados básicos sobre a produção de carvão.......................................... 25

6 Registros de CNPJ e IBAMA nos empreendimentos............................. 31

7 Dados básicos sobre matéria-prima utilizada nos empreendimentos de

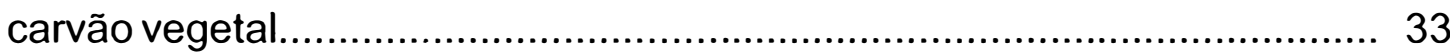

8 Dados sobre embalagem do carvão vegetal no Município........................ 36

9 Dados sobre infra-estrutura e equipamentos existentes.......................... 39

10 Mão-de-obra, remuneração e escolaridade.............................................. 46

11 Estimativa de receita dos empreendimentos e preços do carvão vegetal 52

12 Aspectos ambientais dos empreendimentos de carvão vegetal................ 57

13 Indicação oferecida pelos empreendedores quanto aos fatores que influenciam na qualidade do carvão vegetal no Município de Pedra Bela 62

14 Resultados das análises de friabilidade, densidade aparente e poder calorífico do carvão vegetal do Município de Pedra Bela........................... 63

15 Resultados das análises imediatas e umidade do carvão vegetal do Município de Pedra Bela.

16 Ranking das melhores e piores amostras encontradas no Município de Pedra Bela - SP, conforme resultados do Teste de Dunnet.................... 65 
17 Classificação dos empreendimentos de Pedra Bela, quanto a friabilidade

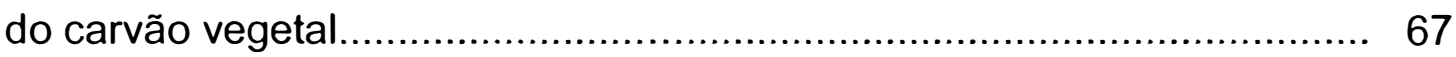

18 Teor de umidade das amostras de carvão vegetal................................. 69

19 Resumo de dados para o conjunto das amostras analisadas.................. 71

20 Análise da variância para a friabilidade das amostras de carvão vegetal... 85

21 Análise da variância para o poder calorífico das amostras de carvão

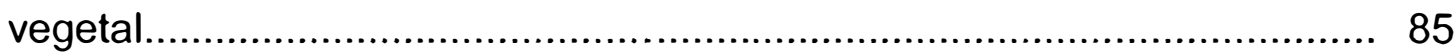

22 Análise da variância para os materiais voláteis das amostras de carvão

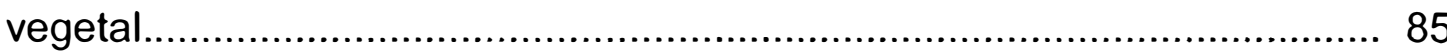

23 Análise da variância para o teor de cinzas das amostras de carvão

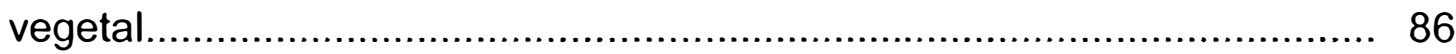

24 Análise da variância para o carbono fixo das amostras de carvão vegetal.

25 Análise da variância para o umidade das amostras de carvão vegetal. 86

26 Análise da variância para a densidade à granel das amostras de carvão vegetal.

27 Análise da variância para a densidade aparente das amostras de carvão vegetal

28 Resultados do teste de Dunnett para a friabilidade das amostras............ 88

29 Resultados do teste de Dunnett para o poder calorífico das amostras...... 88

30 Resultados do teste de Dunnett para os materiais voláteis das amostras.. 89

31 Resultados do teste de Dunnett para o teor de cinzas das amostras..... 90

32 Resultados do teste de Dunnett para o carbono fixo das amostras.......... 91

33 Resultados do teste de Dunnett para a umidade das amostras............... 91

34 Resultados do teste de Dunnett para a densidade à granel das

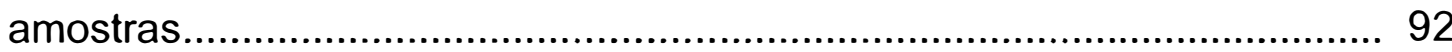

35 Resultados do teste de Dunnett para a densidade aparente das

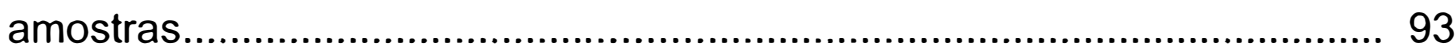

36 Espécies de Eucalyptus utilizadas para produção de carvão vegetal......... 97 


\title{
CARACTERIZAÇÃO SÓCIO-AMBIENTAL E TECNOLÓGICA DA PRODUÇÃO DE CARVÃO VEGETAL NO MUNICÍPIO DE PEDRA BELA, ESTADO DE SÃO PAULO
}

\author{
Autora: ANA MARIA DE MEIRA \\ Orientador: Prof. Dr. JOSÉ OTÁVIO BRITO
}

\section{RESUMO}

O presente trabalho teve por objetivo realizar um diagnóstico sócioambiental e tecnológico da atividade de carvoejamento no Município de Pedra Bela, Estado de São Paulo. $O$ estudo foi conduzido junto a 28 empreendimentos do Município, que desenvolvem atividades de produção e distribuição de carvão vegetal. Para a realização desse trabalho, foram utilizadas informações coletadas in loco, através de entrevistas, visitas de campo, questionários, coleta de amostras de carvão vegetal e dados secundários obtidos de estudos anteriormente efetuados sobre a atividade de carvoejamento. Os principais resultados obtidos demonstram que: i) a maioria dos produtores encontram-se na informalidade e que o contrário ocorre com os produtores-distribuidores; ii) observa-se que a matéria-prima (eucalipto) está se tornando cada vez mais escassa na região, e, que a falta de sustentabilidade das florestas, pode comprometer a atividade no Município; iii) os maiores impactos ambientais advindos da atividade estão relacionados a poluição do ar e disposição inadequada dos finos de carvão; iv) não foi detectada mão-de-obra 
infantil nas carvoarias; $v$ ) as análises laboratoriais confirmaram a boa qualidade do carvão vegetal produzido no Município.

O trabalho indicou a necessidade de ações no sentido da melhoria e fortalecimento das atividades ligadas à cadeia produtiva de carvão vegetal. 


\title{
SOCIO-ECOLOGICAL AND TECHNICAL CHACTERISITICS OF THE VEGETAL COAL PRODUCTION IN "PEDRA BELA" CITY, SÃO PAULO STATE - BRAZIL.
}

\author{
Author: ANA MARIA DE MEIRA \\ Adviser: Prof. Dr. JOSÉ OTÁVIO BRITO
}

\section{SUMMARY}

This study had the purpose of to do a socio-ecological and technical diagnostic of the charcoal activity production in Pedra Bela city, located in São Paulo State of Brazil. The study was conduced with 28 enterprises from the city, who are engaged with the production and the distribution of the charcoal. For the development of this work, was used information colected in loco, through interviews, field visits, questionaries, collection of charcoal samples and secundary data obtained from others previus sutdies about charcoal activity. The main results demonstrate: i) the majority of the producers are informal and the opposite happen with the producer-deliverers; if) is observed that the raw material (Eucalyptus sp.) are becoming scare in the region, and, the lack of forest sustainability could compromise the future of the activity in the city; iii) the great environment impacts from this activity are the air polution and the and inadequate disposal of the charcoal; iv) was not detected children work in the 
activity; v) the laboratory analyses confirm the good quality of the charcoal produced in the city.

The work indicate the need of actions in the mean to improve and fortify the activities related with the productive charcoal. 


\section{INTRODUÇÃO}

A produção de carvão vegetal é uma importante atividade econômica encontrada em cerca de 40 municípios do Estado de São Paulo. Um dos exemplos mais importantes é o Município de Pedra Bela, localizado na região de Bragança Paulista, que possui grande aptidão para a atividade, em função da significativa área de reflorestamento de espécies de eucaliptos e à forte cultura de carvoejamento desenvolvida ao longo do tempo.

Cerca de $79 \%$ da população de Pedra Bela está localizada na zona rural e $21 \%$ na zona urbana (IBGE, 2000). A base econômica do Municipio está centrada na agropecuária, destacando-se a produção de batata, milho, café e vagem e no reflorestamento com eucaliptos, principalmente, Eucalyptus saligna, para fins de produção de carvão vegetal. Conforme relatório anual da Coordenadoria de Assistência Técnica e Integral - CATI (2001), estima-se que $40 \%$ das atividades desenvolvidas no Município de Pedra Bela estejam ligadas ao carvão vegetal. O Município apresenta um renda per capita inferior a meio salário mínimo, o que inclusive o levou a ser incluído no Programa Nacional de Agricultura Familiar - PRONAF.

Diante deste quadro, a valorização da atividade carvoeira na região é de fundamental importância, no sentido de permitir sua adequação aos preceitos atuais, que envolvem fundamentos de ordem tecnológica, econômica, social e ambiental. Entretanto, as ações somente poderão ser conduzidas mediante o conhecimento mais detalhado e aprofundado da atividade. Para atendimento de parte desta demanda, buscou-se neste trabalho: 
- Realizar um levantamento quantitativo e qualitativo dos aspectos tecnológicos, econômicos, sociais e ambientais nos empreendimentos vinculados ao setor de carvão vegetal, no Município;

- Gerar informações que possibilitem a indicação de parâmetros visando a melhoria da atividade de produção e comercialização do carvão vegetal no Município.

Este estudo poderá subsidiar e motivar o desenvolvimento de trabalhos futuros para a implantação de Programas, Planos e Agenda 21 para o Município, de forma a proporcionar a valorização e a sustentabilidade da atividade carvoeira no local, bem como para a melhoria da qualidade de vida da comunidade envolvida.

\subsection{Motivações para a Realização do Estudo}

O presente estudo foi proposto na seqüência do diagnóstico realizado entre os anos de 2000 a 2001, pelo Programa de Qualificação e Certificação da Cadeia Produtiva de Carvão Vegetal do Estado de São Paulo - Pró-Carvão, um Programa criado pelo Sindicato do Comércio Varejista de Carvão e Lenha do Estado de São Paulo, apoiado pelo Serviço de Apoio às Micro e Pequenas Empresas - SEBRAE, e envolvimento de diversas outras instituições, dentre elas o Departamento de Ciências Florestais (ESALQ/USP) e o Instituto de Pesquisas e Estudos Florestais, que deram o apoio técnico. Nessa oportunidade, foi possível verificar, em especial, no Município de Pedra Bela, a demanda dos produtores de carvão vegetal por um estudo que retratasse sua atual situação, que demonstrasse a necessidade de implantação de políticas públicas para a valorização da atividade carvoeira nesse Município. 
O estudo mostrou-se oportuno para responder demandas sociais emergentes, tal como é a atividade carvoeira, que apresenta $77 \%$ dos empreendimentos no Estado de São Paulo, atuando na informalidade (Prócarvão, 2000). Evidentemente, um estudo totalmente completo sobre o assunto exigiria um esforço muito maior do que aquele possível de ser executado numa proposta de Dissertação de Mestrado. Por conta deste fato, o presente trabalho pretendeu realizar um diagnóstico abordando parte do que seria necessário para conclusões definitivas e amplas sobre o tema. Apesar disto, o estudo pretendeu oferecer informações iniciais para subsidiar ações visando a solução de alguns dos problemas detectados e, sobretudo, despertar a atenção dos especialistas e autoridades competentes para a continuidade de novas ações. 


\section{REVISÃO DE LITERATURA}

\subsection{Aspectos Gerais da Produção e Consumo de Carvão Vegetal no Brasil}

O Brasil é o maior produtor mundial de carvão vegetal. Mais de dois terços de sua produção é destinada à industria siderúrgica e metalúrgica, principalmente em Minas Gerais, sendo que, nos demais Estados brasileiros o destaque fica por conta do seu uso na cocção de alimentos, como é o caso de São Paulo (Figura 1).

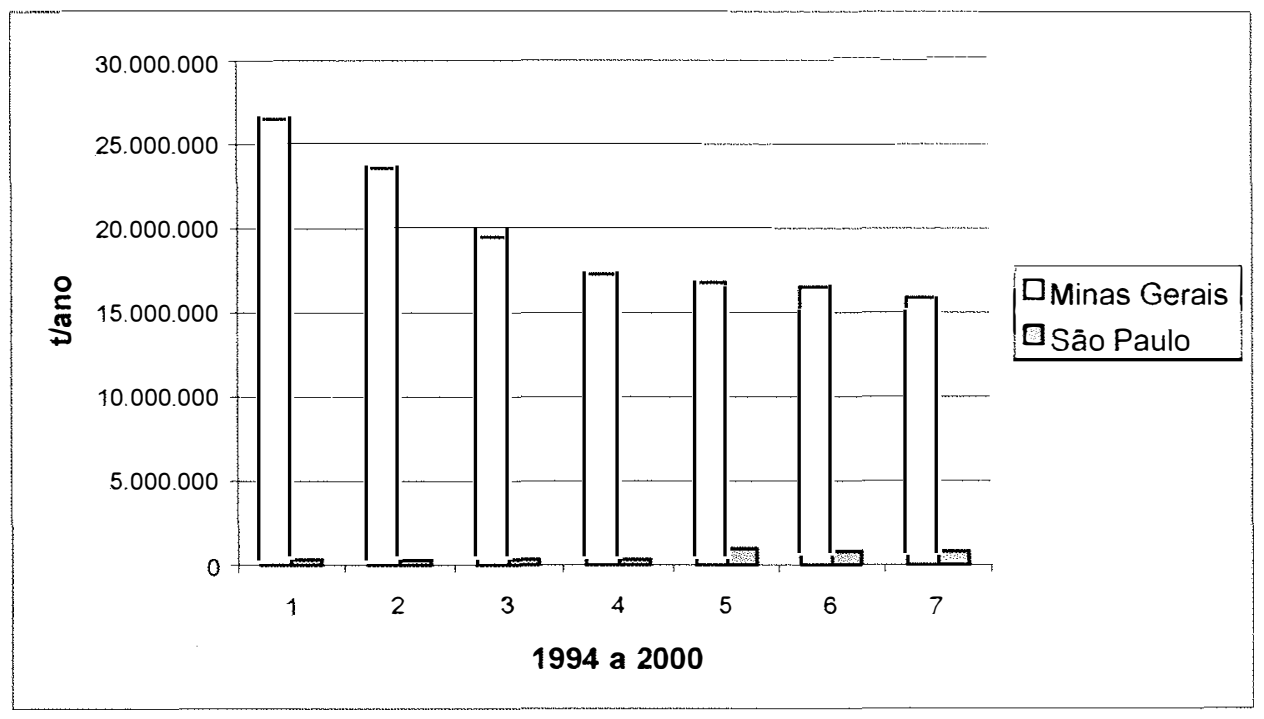

Fonte: ABRACAVEIANFPC, 2001

Figura 1 - Consumo de carvão vegetal em São Paulo e em Minas Gerais

O Brasil também é o único país do mundo a utilizar o carvão em larga escala como insumo industrial. Estima-se que o país produza anualmente cerca 
de 24 milhões de metros cúbicos de carvão vegetal, sendo mais de $70 \%$ oriunda de florestas plantadas.

Conforme Castro (1994), a madeira nativa ainda utilizada para a produção do carvão vegetal é originária, em sua maioria, de desmatamentos de cerrados encontrados, principalmente, no Brasil Central (MG, MT e GO). É de se supor que, isto ocorra como forma de utilização do subproduto originário da ocupação agrícola destas áreas.

No Estado de São Paulo, conforme recente levantamento efetuado através do Pró-Carvão (2000), cerca de 95\% da matéria-prima empregada na produção de carvão vegetal é oriunda de reflorestamentos, principalmente de eucalipto.

Tabela 1. Origem da matéria-prima para a produção de carvão vegetal, no Brasil

\begin{tabular}{cccccc}
\hline Anos & $\begin{array}{c}\text { Carvão vegetal origem } \\
\text { nativa (mdc) }\end{array}$ & $\%$ & $\begin{array}{c}\text { Carvão vegetal } \\
\text { reflorestamento }(\mathrm{mdc})\end{array}$ & $\%$ & Total \\
\hline 1991 & 17.876 & 57,7 & 13.102 & 42,3 & 30.978 \\
1992 & 17.826 & 61,1 & 11.351 & 38,9 & 29.177 \\
1992 & 17.923 & 56,5 & 13.777 & 43,5 & 31.700 \\
1994 & 15.180 & 46,0 & 17.820 & 54,0 & 33.000 \\
1995 & 14.920 & 48,0 & 16.164 & 52,0 & 31.084 \\
1996 & 7.800 & 30,0 & 18.200 & 70,0 & 26.000 \\
1997 & 5.800 & 25,0 & 17.800 & 75,0 & 23.600 \\
1998 & 8.600 & 32,6 & 17.800 & 67,4 & 26.400 \\
1999 & 8.070 & 30,0 & 18.830 & 70,0 & 26.900 \\
2000 & 7.200 & 28,3 & 18.200 & 71,7 & 25.400 \\
\hline
\end{tabular}

Fonte: ABRACAVE/2002 - Ano base 2000

$10^{3} \mathrm{mdc}$ : metros cúbicos de carvão

O carvão vegetal produzido no Brasil está voltado em sua maior parte $(64,6 \%)$ para a produção de ferro-gusa e somente cerca de $11 \%$ está destinado ao uso doméstico. 
O carvão vegetal é produzido a partir da madeira pelo processo de carbonização ou pirólise. Ao contrário do que aconteceu nos países industrializados, no Brasil, o uso industrial do carvão vegetal continua sendo largamente praticado, em função do elevado potencial de produção de matériaprima de origem florestal como é o caso da madeira de eucalipto.

Para Oliveira \& Almeida (1982), a produção e utilização do carvão vegetal como fonte energética esta fundamentalmente embasado em dois motivos fundamentais:

a) por ser uma fonte renovável;

b) alternativa estratégica para um país carente de redutor fóssil.

O carvão vegetal é um resíduo sólido que se obtém da carbonização da madeira, em que a mesma é queimada ou aquecida numa atmosfera restrita de ar, onde vão sendo expulsos a água, os compostos voláteis, uma fração de compostos orgânicos condensáveis à temperatura ambiente, e outros, sem que ocorra a combustão total, devido a pouca quantidade de oxigênio.

A madeira sofre um processo de carbonização quando aquecida em presença de quantidades controladas de oxigênio, em temperaturas acima de $300^{\circ} \mathrm{C}$, desprendendo vapor d'água, líquidos orgânicos e gases não condensáveis, ficando como resíduo o carvão. A produção de carvão vegetal é o mais antigo processo de transformação química para a utilização da madeira (Gomes \& Oliveira, 1982).

A produção brasileira de carvão vegetal é obtida, em sua maioria através de fornos de alvenaria, comumente conhecidos como fornos de superfície. Quando se trata de pequenos empreendimentos, o controle se torna muito difícil, dando em conseqüência um produto com propriedades variáveis .

A prática de produção de carvão ainda é primitiva e o controle operacional dos fornos de carbonização é pequeno, exercitando-se muito pouco o controle qualitativo e quantitativo na sua produção. Além disso, a tecnologia empregada descarta, através da emissão de gases, milhares e 
milhares de toneladas de componentes químicos, pois no processo de carbonização, aproveitam-se apenas de 30 a $40 \%$ da madeira na forma de carvão vegetal (Brito, 1990a).

Segundo Netto (1980), torna-se cada vez mais necessário o desenvolvimento de pesquisas e de tecnologias, que ainda são incipientes em face das excelentes perspectivas que oferece o carvão vegetal como promissora e eficaz alternativa energética, tanto para a produção siderúrgica, como para diversos outros segmentos industriais, domésticos e da atividade econômica em geral, inclusive como possivel substituto dos derivados do petróleo e em outras destinações industriais e rurais.

\subsection{Aspectos Sócio-ambientais da Produção de Carvão Vegetal no Brasil}

É cada vez mais crescente a importância de estudos junto aos pequenos produtores, por conta das questões sócio-ambientais envolvidas, principalmente por ações de ocupação e exploração inadequada da área rural que, direta ou indiretamente, comprometem a sobrevivência das espécie animais, vegetais e humanas e envolvem a redução da qualidade de vida do homem e do meio ambiente. Em alguns destes aspectos, enquadra-se a atividade de produção de carvão vegetal que, em muitas regiões do país, ocorre de forma desarticulada.

A atividade carvoeira é para muitos pequenos produtores uma oportunidade única para complementação de renda e a preocupação com a subsistência geralmente é prioritária em relação às questões ambientais. Além disso, geralmente os requisitos básicos da legislação trabalhista, como o registro profissional, não são cumpridos. O carvoeiro não tem perspectiva, não está organizado, e em geral fica a mercê do intermediário. Além disso, não tem acesso aos equipamentos básicos de proteção individual para o 
desenvolvimento do seu trabalho, tais como botinas, chapéus, luvas e máscaras (Prado,1999).

O carvoejamento, em alguns estados do Brasil, está intimamente ligado a um sistema de escravidão por dívida, que tem sido objeto de repúdio doméstico e internacional. Em 1994, a atenção pública foi atraída para a existência de escravidão no Brasil, por ocasião de denúncias trazidas perante a Organização Internacional do Trabalho em Genebra (Sutton, 1994).

O carvão vegetal é freqüentemente produzido por famílias, incluindo em algumas localidades as crianças, que trabalham para um intermediário, que fornecem o carvão para as empresas legalizadas. Os carvoeiros são forçados a comprar todos os suprimentos de seus próprios patrões e dados aos preços elevados para os suprimentos e as pequenas somas creditadas por volume de carvão produzido, suas dividas crescem e se tornam difíceis de serem liquidadas. Na prática, os trabalhadores jamais recebem pagamentos em dinheiro, apenas créditos para o abatimento parcial de suas dívidas. Pistoleiros asseguram-se de que os trabalhadores não fujam e muitas vezes a única saída do sistema é a morte (Prado, 1999).

O trabalhador ligado à atividade de carvão vegetal desempenha suas funções como diarista ou como meeiro no corte de madeira e/ou diretamente nos fornos de carbonização e o trabalho nas carvoarias torna-se, em determinadas épocas do ano, a única oportunidade de receita imediata.

Segundo estudos realizados pela Associação Brasileira de Florestas Renováveis - ABRACAVE (2002), a produção de carvão vegetal para a siderurgia emprega cerca de 128.400 trabalhadores. Esse dado pode estar subestimado, uma vez que muitos empreendimentos atuam na informalidade. O Estado de São Paulo é caracterizado por pequenos empreendimentos voltados à produção de carvão para uso doméstico e emprega hoje, diretamente, cerca de 2.187 trabalhadores, conforme um diagnóstico realizado 
pelo Pró-Carvão (2000), junto a 781 empresas, todavia, esse dado pode ser maior, porque ainda são escassos os levantamentos em relação a esse setor.

Souza (2000), cita que em Minas Gerais, por exemplo, a mão-de-obra predominante no carvoejamento é jovem. Estes, temporariamente, deixam suas famílias para muitas vezes em condições insalubres garantir o seu precário sustento.

As famílias chegam a residir próximas às áreas de carvoejamento e a viverem em ranchos improvisados e cobertos de palhas, junto aos fornos de produção de carvão vegetal e sujeitas aos mais diversos impactos da ação poluidora proveniente da carbonização.

Ainda segundo Souza (2000), não tem havido investimentos na tecnologia de conversão e de utilização dos sub-produtos oriundos da carbonização, podendo-se notar que, historicamente, a produção de carvão vegetal vem se revelando uma das atividades econômicas mais depredadoras de nossos recursos naturais. Ela utiliza tecnologias ultrapassadas, impõe condições desumanas de vida e trabalho e administra a matéria-prima florestal de forma inconseqüente. Além disso, vem burlando sistematicamente a legislação tributária, ambiental e trabalhista (Prado, 1999).

Segundo Brito (1990b), apesar da atividade de carvão vegetal não se encontrar concentrada num único ponto, havendo grande dispersão de centros de produção no meio rural, o resultado global das emissões de gases é importante, tanto no que se refere a de perda de produtos químicos valiosos, que poderiam ser economicamente recuperados, bem como aos aspectos ambientais. Nesse contexto, o autor aponta ainda que "a adoção de soluções de mais amplo espectro para a recuperação de outros produtos da carbonização, implicam em profundas alterações na sistemática hoje utilizada no Brasil. São alterações que exigem, em primeiro lugar, a adoção de modernas tecnologias e modernos conceitos de agroindústria, fugindo da definição que ainda se dá a esta atividade em nosso País, como sendo algo 
marginal e secundário da atividade rural. Além disso, a sociedade não admite mais, qualquer que seja a situação ou atividade, a não agregação de custos relacionados à necessidade da minimização de impactos sobre o ambiente".

Para Netto (1980), a mobilização energética das florestas destinadas à produção de carvão vegetal, só poderá ser conseguida a partir da utilização de subprodutos e de processos acoplados, que utilizem e valorizem os resíduos vegetais decorrentes da exploração das florestas com finalidade carvoeira.

\subsection{Qualidade do Carvão Vegetal}

Para Brito (1994), o conceito de qualidade tem sido uma das questões mais discutidas dentro do moderno sistema produtivo industrial mundial, o que tem resultado em profundas transformações na filosofia de trabalho das empresas. Há uma crescente tomada de consciência de que melhorias contínuas na qualidade são freqüentemente necessárias para atingir e assegurar um bom desempenho econômico.

Segundo Netto (1980), quando se fala em carvão vegetal deve-se também considerar suas propriedades e, consequentemente, a necessidade de controle da qualidade do produto. Praticamente pouco valorizada, e muito pouco ainda se conhece de suas propriedades ligadas aos parâmetros de carbonização. Diversos são os fatores que influenciam na qualidade do carvão vegetal, mas de forma geral a qualidade depende da: espécie da madeira; tamanho da madeira, método de carbonização.

A espécie da madeira é muito importante porque madeiras densas produzem carvão denso. O tamanho da madeira influencia porque pedaços pequenos produzem carvões mais duros e mais densos que a madeira em pedaços grandes por que tem menos tendência de estourar durante a carbonização e o método influencia no tamanho do carvão produzido. A carbonização lenta quebra menos que o carvão produzido em métodos rápidos. 
A temperatura também é outro fator muito importante porque influência no peso do metro cúbico e no teor de carbono fixo do carvão obtido. Altas temperaturas de carbonização produzirão carvão com muito carbono fixo, mas tão frágil e miúdo que será inadequado para determinados usos. A caracterização e incorporação dos principais parâmetros de qualidade constituem uma importante maneira de diferenciação do carvão vegetal no mercado (Gomes et al. ${ }^{1}$, citados por Vale et al., 2001).

Apesar do carvão vegetal constituir-se em uma matéria-prima de grande importância na siderurgia brasileira, muito pouco se fez para a padronização dos testes que permitam distinguir carvões com diferentes características e, ainda, correlacionar as suas propriedades com a performance dos aparelhos de redução (Gomes \& Oliveira, 1982).

São poucas as normas de procedimento de controle de qualidade de carvão vegetal objetivando a padronização de tais procedimentos. É comum verificar-se discrepâncias bem acentuadas entre ensaios realizadas por empresas ou instituições. Isto, na maioria dos casos, devido a utilização de procedimentos não-normatizados (Oliveira et al., 1982a).

7 GOMES, P. A.; OLIVEIRA, J. B. ; MENDES, M.G.; Produção de carvão vegetal: aspectos técnicos. Belo Horizonte: Fundação Centro Tecnológico de Minas Gerais, 1982. ( Série Publicações Técnicas, 8). 
A maior parte da produção brasileira de carvão vegetal é obtida através de fornos de alvenaria ditos de superfície. Nestes fornos parte da madeira é queimada durante a carbonização e torna-se muito difícil, devido as suas características, o controle do processo, o que resulta em um produto de propriedades bastante variáveis. Há necessidade de maior controle para a produção de carvão vegetal, através da utilização de técnicas que proporcionem a otimização da produção e qualidade do produto (Oliveira et al., 1982b).

Não existem estudos publicados sobre quais são os parâmetros para se classificar um carvão ideal para uso doméstico. A bibliografia existente restringe-se apenas à indicação do que é um carvão desejável para aplicação em siderurgia, que deve apresentar umidade abaixo de 10\%, carbono fixo superior a $65 \%$, teor de cinzas inferior a $5 \%$ e densidade à granel superior a $200 \mathrm{~kg} / \mathrm{m}^{3}$.

Ainda segundo Brito ${ }^{2}$, existem algumas sugestões de exigências para o carvão vegetal utilizados para fins domésticos, apresentada na Tabela 2.

${ }^{2}$ BRITO, J. O. (Departamento de Ciências Florestais da Escola Superior de Agricultura "Luiz de Queiroz", Piracicaba). Comunicação Pessoal, 2002. 
Tabela 2. Indicações de parâmetros para qualidade do carvão vegetal

\begin{tabular}{lcc}
\hline \multicolumn{1}{c}{ Parâmetro } & Tolerável & Uso Doméstico \\
\hline Carbono fixo (\%) & $\geq 75$ & $>$ \\
Cinzas (\%) & $\leq 5$ & $<$ \\
Umidade (\%) & $\leq 5$ & $<$ \\
Densidade à granel $\left(\mathrm{kg} / \mathrm{m}^{3}\right)$ & $\geq 200$ & $>$ \\
Granulometria $<10 \mathrm{~mm}(\%)$ & $\leq 5$ & $<$ \\
Granulometria $>35 \mathrm{~mm}(\%)$ & $*$ & $*$ \\
${ }^{*}$ Especificação não obtida ou dependente de avaliação "caso à caso"
\end{tabular}

\subsection{O Município de Pedra Bela}

O Município de Pedra Bela possui 5.609 habitantes (IBGE, 2000) e está situado no sudoeste do Estado de São Paulo, a $110 \mathrm{~km}$ da capital, na região administrativa de Campinas e região de governo de Bragança Paulista. A cidade está localizada na Serra da Mantiqueira, apresenta 1.100 metros de altitude e $19^{\circ} \mathrm{C}$ de temperatura média anual.

O Município apresenta uma extensão territorial de $157 \mathrm{~km}^{2}$, é essencialmente agrícola, composto por pequenas e médias unidades de produção agrícola (UPAS), sendo os estabelecimentos agrícolas apresentam área inferior a 500ha (Tabela 3 e Figura 2). 
Tabela 3. Distribuição das áreas nas unidades de produção agrícola (UPAS), do Município de Pedra Bela - SP

\begin{tabular}{ccccc}
\hline $\begin{array}{c}\text { Tamanho da } \\
\text { área (ha) }\end{array}$ & N. de UPAS & $\begin{array}{c}\text { \% de UPAS por Área Total(ha) } \\
\text { tamanho }\end{array}$ & \% da área tot al \\
\hline $\begin{array}{c}\text { 1 a } 2 \\
\text { a } 5\end{array}$ & 21 & 4 & 24 & 0,2 \\
5 a 10 & 137 & 26 & 479 & 4 \\
10 a 20 & 92 & 17 & 702 & 5 \\
20 a 50 & 103 & 19 & 1.530 & 11 \\
50 a 100 & 106 & 20 & 3.374 & 25 \\
100 a 200 & 18 & 9 & 3.399 & 25 \\
200 a 500 & 6 & 3 & 2.190 & 16 \\
Tot al & 532 & 1 & 1.912 & 14 \\
Médio & 66,5 &.$--\cdots 0$ & 13.610 & 100 \\
\hline
\end{tabular}

Fonte: Secretaria de Agricultura e Abastecimento do Estado de São Paulo

Projeto LUPA, 1996

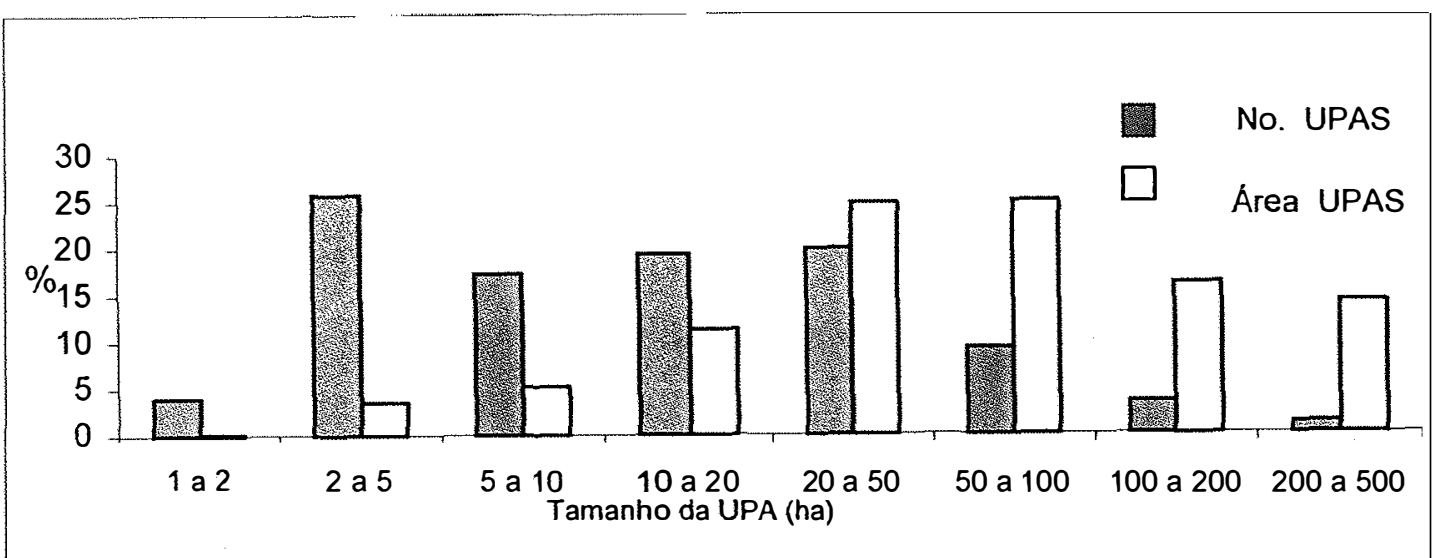

Fonte: Secretaria de Agricultura e Abastecimento do Estado de São Paulo, Projeto LUPA.

Figura 2 - Distribuição percentual das unidades de produção agrícola (UPAS), por tamanho, no Município de Pedra Bela, 1995/96

Cerca de $60 \%$ da mão-de-obra urbana é empregada pela Prefeitura Municipal. O Município chegou a possuir cerca de 12.000 habitantes a 30 anos atrás, todavia, dada a falta de perspectivas de trabalho e de estudos, principalmente para os mais jovens, ocorreu grande migração para os Municípios de Jundiaí, Campinas e São Paulo. 
Atualmente, a maior parte do trabalho é temporário e a mão-de-obra rural do Município está voltada ao reflorestamento, a produção do carvão e a suinocultura.

Segundo Relatório Anual da CATI de Pedra Bela (2001), " se não ocorrer uma mudança substancial na política agrícola, as atividades produtivas do município tendem a diminuir cada vez mais, em detrimento do desenvolvimento sócio-econômico do local".

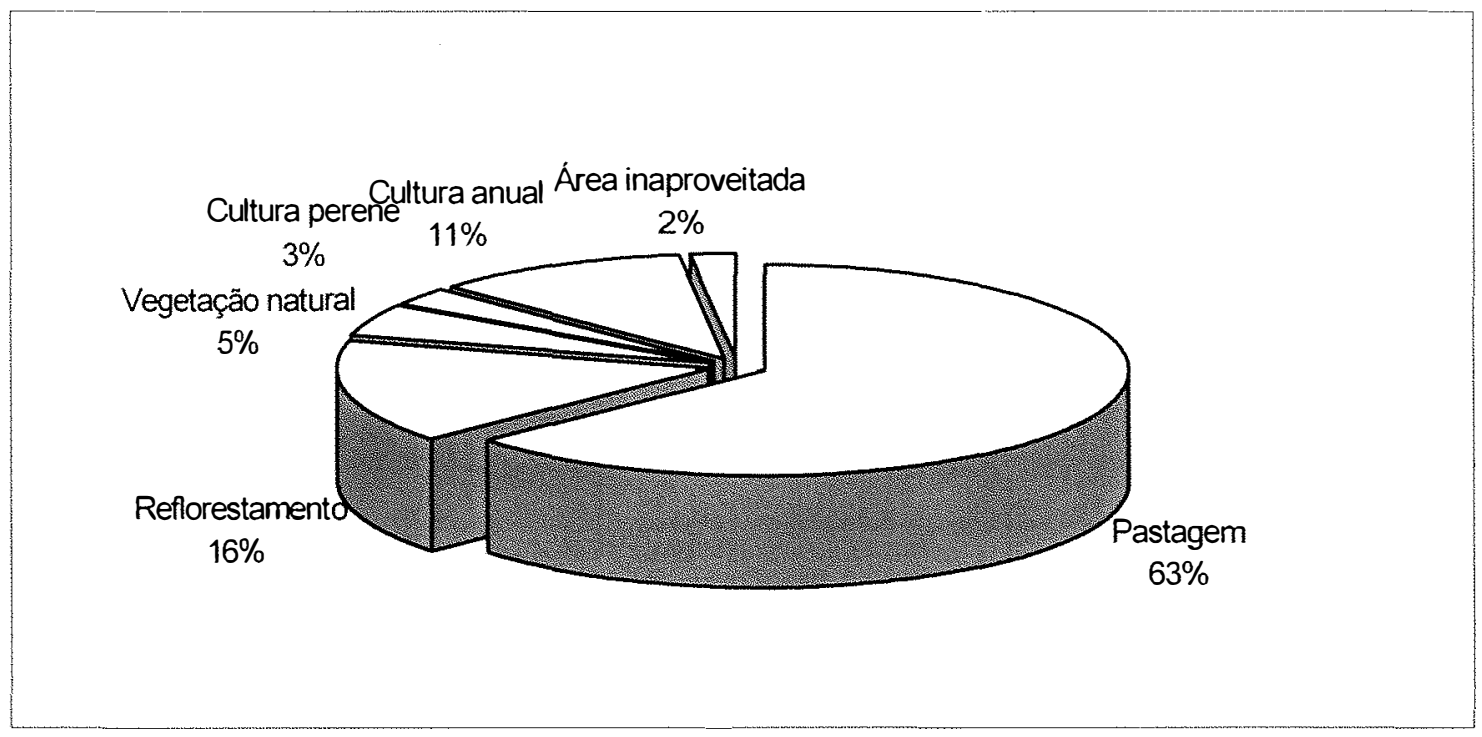

Fonte: Secretaria de Agricultura e Abastecimento do Estado de São Paulo, LUPA (1996).

Figura 3 - Área cultivada, Município de Pedra Bela, Estado de São Paulo, $1995 / 96$.

Atualmente a utilização da terra no Município destina-se em sua maioria para a pastagem. Há trinta anos atrás predominava o cultivo da batata, mas com a exaustão do solo, passou a ser substituída pela criação extensiva de bovinos. Somente $14 \%$ da área do Município é destinado a algum tipo de 
cultura (anual ou perene) e cerca de $16 \%$ é utilizada para fins de reflorestamento com espécies de Eucalyptus.

A maioria das florestas de eucalipto no Município não recebem nenhum tipo de manejo, o que vem dificultando a produção de carvão vegetal no local dada a escassez de madeira, que é a principal matéria-prima para carvoejamento na região. 


\section{MATERIAL E MÉTODOS}

\subsection{Local de Estudo}

O estudo foi conduzido em propriedades ligadas à atividade de carvão vegetal do Município de Pedra Bela, na região administrativa de Bragança Paulista, no Estado de São Paulo (figura 4), localizado a $22^{\circ} 58^{\prime \prime} 30^{\prime}$ de latitude sul e 46³2"30' de longitude.

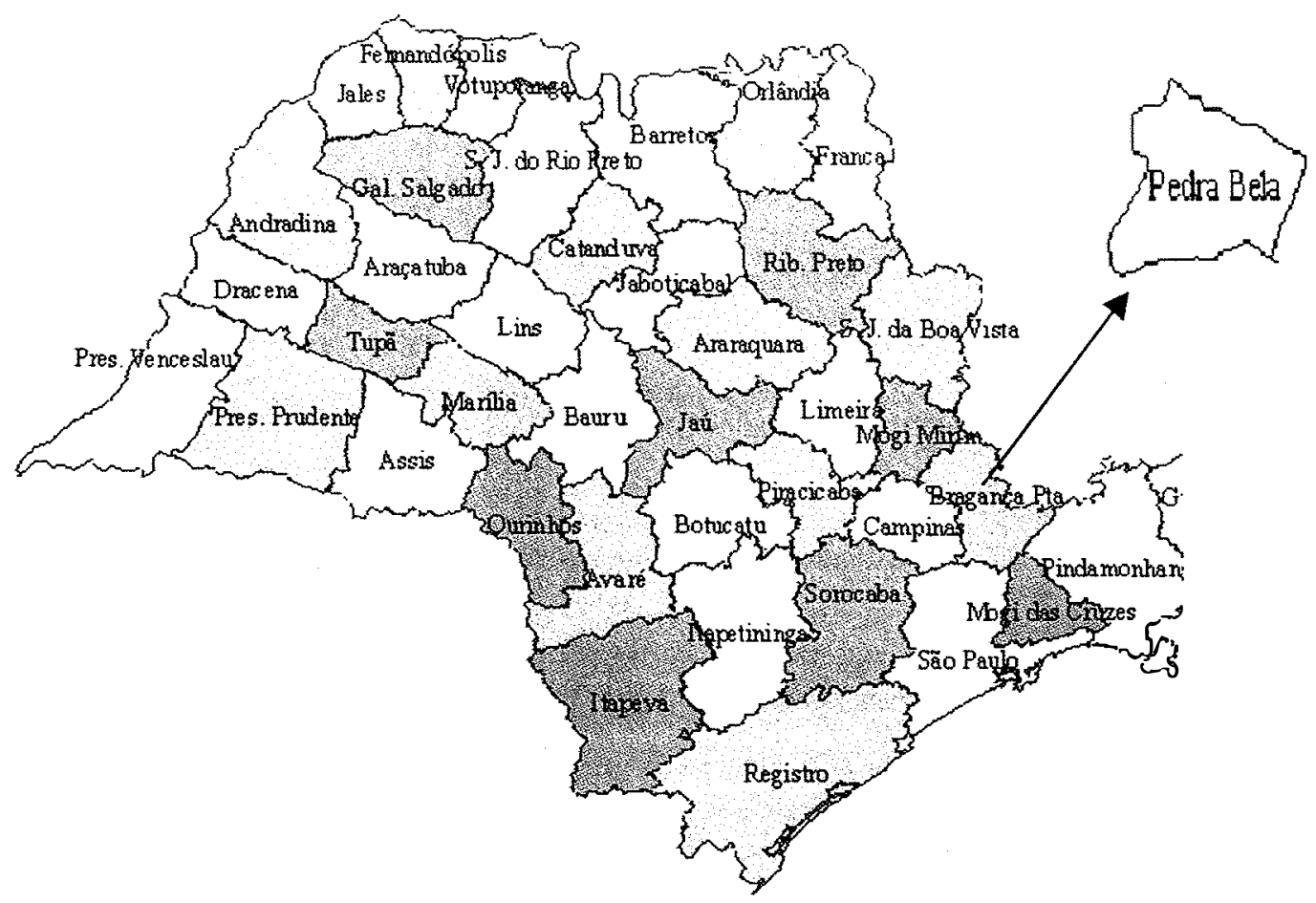

Figura 4 - Localização do Município de Pedra Bela - SP 


\subsection{Amostragem dos Empreendimentos}

O estudo foi realizado no período de julho à agosto de 2001 tendo sido avaliadas 28 propriedades ligadas a atividade de carvão vegetal, o que permitiu a inclusão da maioria dos empreendimentos produtores vinculados à atividade no Município.

\subsection{Coleta de Dados}

Foram utilizados nesse trabalho diversos métodos de coleta de dados de forma a gerar informações que subsidiassem as discussões de âmbito social, ambiental e tecnológico.

Foram aplicados formulários com cerca de 30 itens aos proprietários e funcionários vinculados aos empreendimentos (Apêndice 1). Buscou-se avaliar os seguintes aspectos:

3.3.1 Ambientais: (i) geração de resíduo; (ii) nivel de conservação dos mananciais (área de preservação permanente, demais tipos de vegetação, recursos hídricos, etc), quando existirem; (iii) impactos gerados pela poluição (ar, visual, solo); ( iv) existência de erosão e forma de contenção;

3.3.2 Sociais: (i) condições de trabalho; (ii) jornada, (iii) remuneração, (iv) equipamentos de segurança, (v) trabalho infantil, (vi) grau de escolaridade, (vii) gênero, (viii) expectativas em relação à atividade;

3.3.3 Tecnológicos: (i) equipamentos existentes, (ii) forma de manuseio e capacitação para uso de equipamentos, (iii) benfeitorias, (iv ) expectativas em relação a aquisição de novos equipamentos e (v) qualidade do produto;

3.3.4 Econômicos: (i) preço do carvão, (ii) preço da madeira e do carvão (iii) salários, (iv) produção atual e estimada. 
- dados secundários: informações pré-existentes sobre os setor carvoeiro, originários da Secretaria da Agricultura do Estado de São Paulo e da Casa da Agricultura do Municipio;

- dados diretos: através de visitas de campo, preenchimento de formulários pelos proprietários, entrevista semi-estruturada com lideranças locais. Além disso, procedeu-se a coleta de amostras do carvão vegetal para análises laboratoriais (Apêndice1.1).

\subsection{Análise Laboratorial}

Para as análises laboratoriais do carvão vegetal, foram coletadas de forma aleatória, cerca de $8 \mathrm{~kg}$ de amostras em cada um dos 25 empreendimentos. Foram efetuadas os testes de friabilidade, densidade à granel e aparente, umidade, análise imediata e poder calorífico. Para todos os testes foram analisadas 25 amostras com 3 repetições para cada teste, exceto para o ensaio de densidade à granel, cujo material coletado foi suficiente para a realização de apenas 2 repetições.

Os testes de qualidade foram realizados no Laboratório de Química, Celulose e Energia do Departamento de Ciências Florestais, ESALQ/USP.

\subsubsection{Teste de Tamboramento}

Para a determinação do grau de friabilidade do carvão utilizou-se o teste de tamboramento. O teste consistiu em se colocar uma amostra de 500 gramas de carvão previamente selecionado entre 20 e $60 \mathrm{~mm}$ em um tambor rotativo, submetê-lo a 500 voltas e a uma velocidade de 30 rotações por minuto. Logo após o carvão foi passado em uma peneira de $20 \mathrm{~mm}$. De acordo com o percentual de material com bitola abaixo dessa dimensão (finos) o carvão era então classificado de acordo com a Tabela 4. 
Tabela 4. Classificação do carvão vegetal quanto a sua friabilidade

\begin{tabular}{lc}
\hline \multicolumn{1}{c}{ Friabilidade } & $\%$ de fino gerado \\
\hline Muito friável & $>30$ \\
Bastante friável & $25-30$ \\
Medianamente friável & $15-25$ \\
Pouco friável & $10-15$ \\
Muito pouco friável & $<10$ \\
\hline
\end{tabular}

Fonte: Norma ABNT NBR 8740

\subsubsection{Densidade Aparente e à Granel}

A densidade é uma propriedade bastante importante e em não havendo prejuizo para as outras propriedades, a densidade do carvão vegetal deve ser a maior possivel.

O ensaio para obtenção da densidade aparente foi realizado conforme o método sugerido pela Associação Brasileira de Normas Técnicas - ABNT NBR 9165 e para densidade à granel foi efetuado conforme norma da ABNT NBR 6922. Ambos os testes foram aplicados nesse trabalho por se mostrarem os mais eficientes e usuais para a qualificação do carvão vegetal. Em termos técnicos, o primeiro oferece resultados básicos e o segundo é usado na prática comercial do carvão vegetal.

\subsubsection{Teor de Umidade}

A umidade é a perda percentual de massa experimentada pelo carvão quando submetido a um aquecimento em estufa estabilizada a temperatura em torno de $105^{\circ} \mathrm{C}$. O teste foi realizado conforme recomendação da ABNT NBR 8112. 


\subsubsection{Análise Imediata}

O ensaio consiste na determinação dos teores de umidade, materiais voláteis, carbono fixo e cinzas objetivando uma análise imediata. Os testes foram efetuados segundo a ABNT NBR 8112.

\section{- Teor de cinzas}

A cinza é o resíduo de óxidos minerais obtidos pela combustão completa do carvão. Para assegurar a combustão completa o carvão permanece na mufla por um longo período (6 horas). O resíduo oxidado obtido é calculado como teor de cinzas do carvão vegetal.

\section{- Carbono Fixo e Material Volátil}

Quando se efetua o aquecimento do carvão vegetal, parte do carbono sai junto com os gases, como elemento formador das moléculas de $\mathrm{CO}, \mathrm{CO}_{2}$ e dos hidrocarbonetos. Essa fração é denominada de material volátil. Uma outra quantidade de carbono permanece relativamente intacta e como não sai junto com a matéria volátil, recebe a denominação de carbono fixo. Na prática determina-se o teor de material volátil e carbono fixo aquecendo-se o carvão em temperatura em torno de $900^{\circ} \mathrm{C}$.

\subsubsection{Análise do Poder Calorífico Superior do Carvão Vegetal}

A análise consistiu na determinação da quantidade de calor liberadas pela combustão do carvão vegetal, em bomba calorimétrica, conforme a norma da ABNT NBR 8633. 


\subsection{Análises dos Dados}

Foi realizada o estudo qualitativo e quantitativo dos resultados dos formulários e entrevistas obtidos, através da análise observacional dos dados.

A análise estatística foi aplicada para os ensaios de laboratório efetuados, utilizando-se para isto, a análise de variância e o teste de Dunnett. As melhores amostras foram obtidas com a ordenação das médias, aplicandose o teste Dunnett, onde se considerou a melhor amostra como referência, através do contraste da mesma com cada uma das amostras. 


\section{RESULTADOS E DISCUSSÕES}

\subsection{Resultados Sobre a Produção do Carvão Vegetal}

\subsubsection{Tipo de Empreendimento, Capacidade de Produção e Matéria-Prima}

As Tabelas de 5 a 9 apresentam resultados básicos sobre a produção de carvão vegetal no Município de Pedra Bela. llustrações sobre aspectos mais específicos são apresentados nas Figuras de 5 a 18.

O Município de Pedra Bela é reconhecido pela grande concentração de produtores de carvão vegetal (Figura 5). Em geral, a atividade carvoeira subdivide-se em diversos segmentos ligados à produção e distribuição do carvão vegetal até alcançar o mercado consumidor. Comumente, esta cadeia produtiva é composta por produtores, e/ou produtores-distribuidores, intermediários e varejistas.

O produtor é geralmente o proprietário ou arrendatário dos fornos que produz o carvão vegetal e o vende à granel, em sacos de $20 \mathrm{Kg}$.

$O$ produtor-distribuidor é aquele que além de produzir comercializa o carvão vegetal com a marca própria ou de terceiros.

o intermediário é aquele que retira o carvão vegetal junto aos produtores, embala o produto com a marca de terceiros e os vendem para os distribuidores. 
O varejista é, geralmente, proprietário de algum estabelecimento comercial e é responsável pelo contato direto com os consumidores de carvão vegetal. Este geralmente comercializa as marcas próprias de carvão embalado por produtores e/ou intermediários ou comercializa as marcas de terceiros. Esta categoria não foi alvo de avaliação neste estudo.

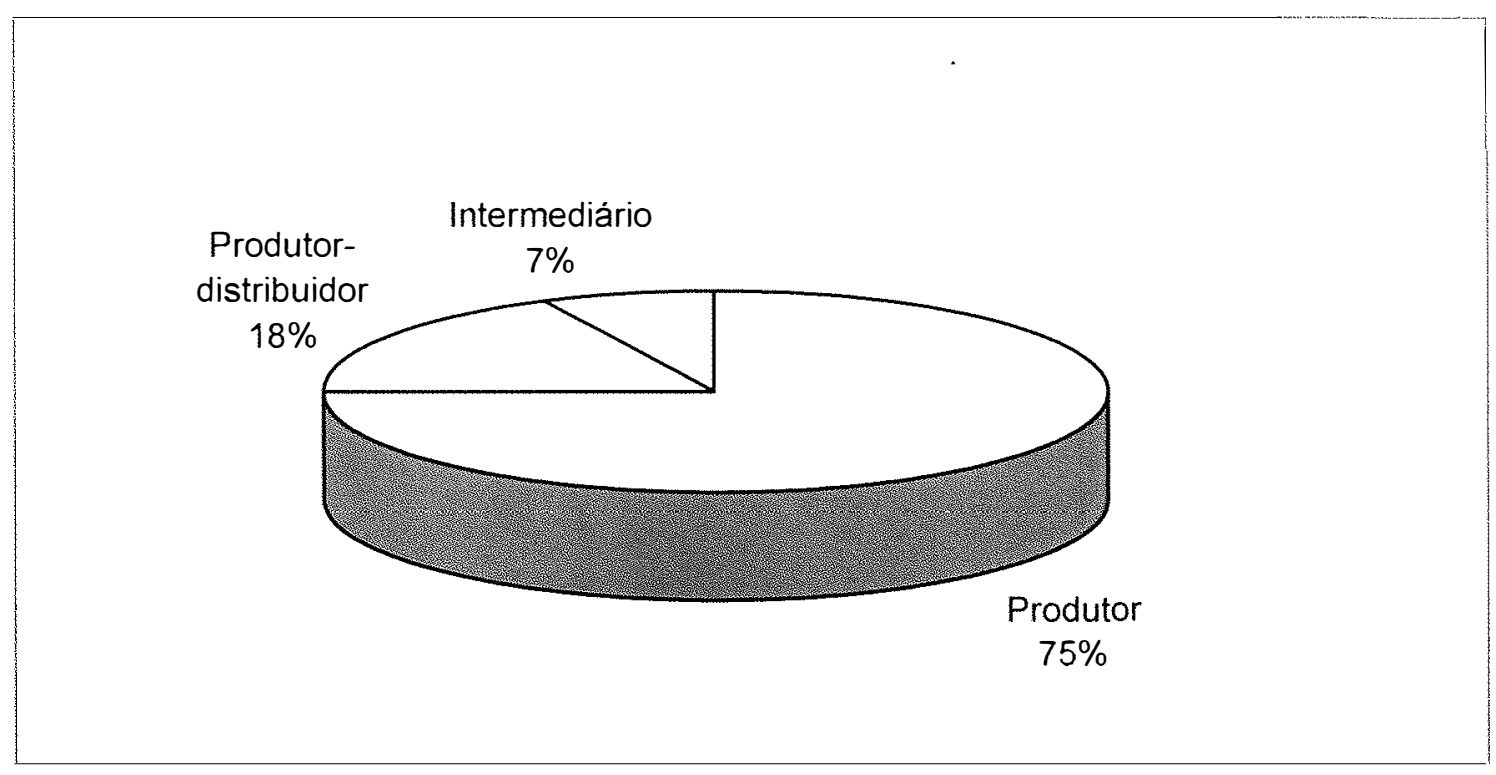

Figura 5 - Tipo de atividade desenvolvida nos empreendimentos de carvão vegetal 


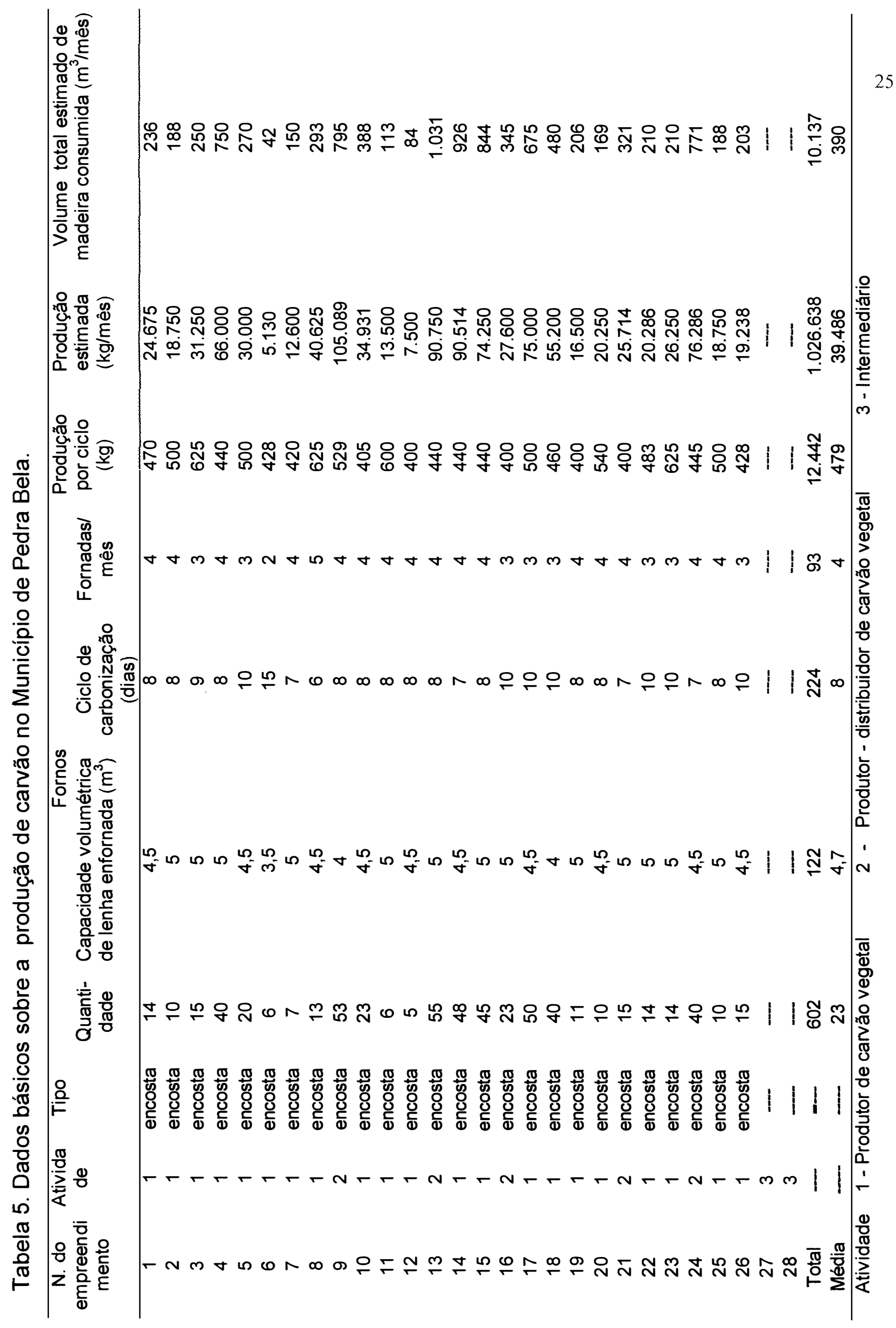




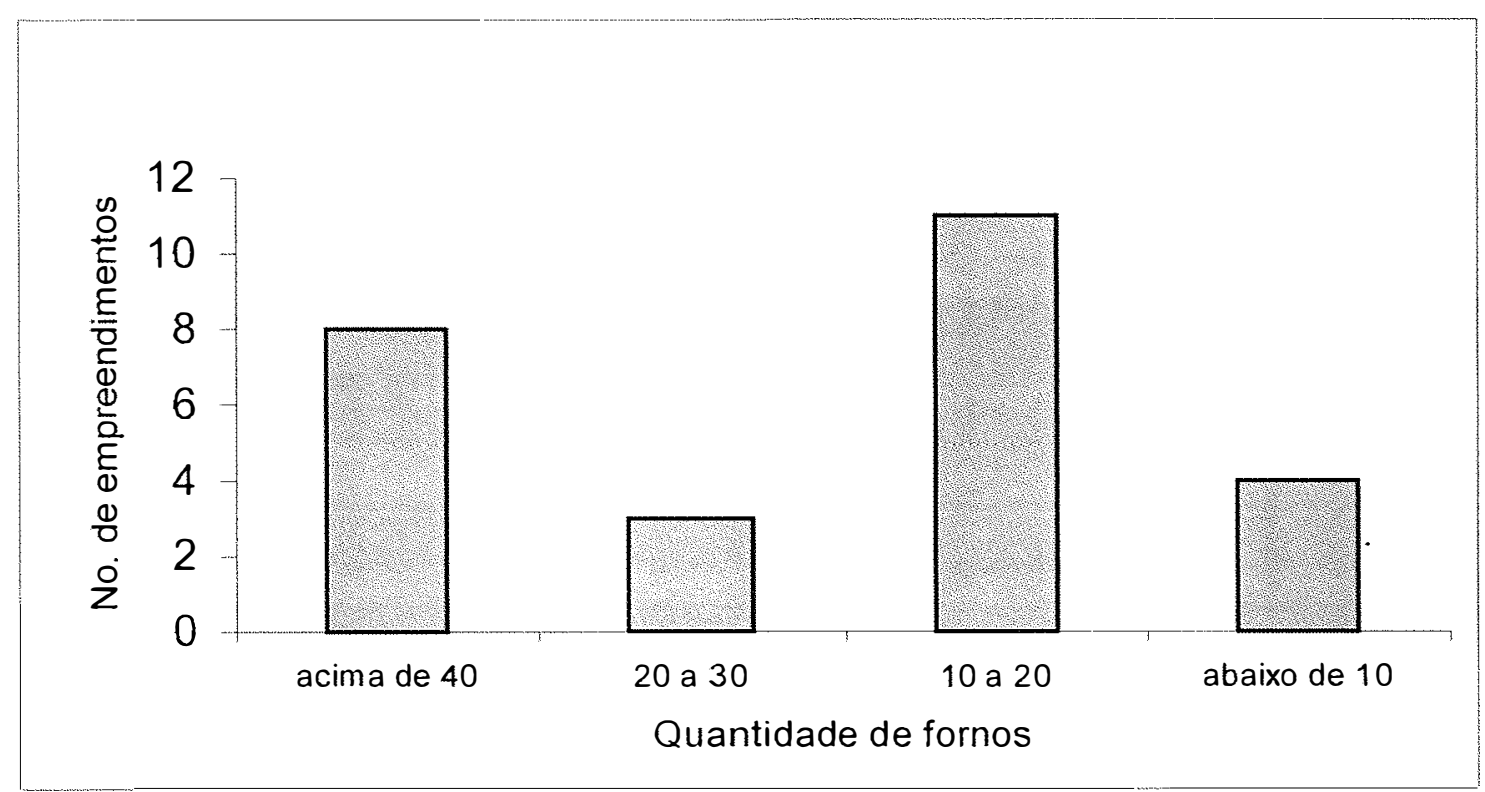

Figura 6 - Número de fornos nos empreendimentos de carvão vegetal

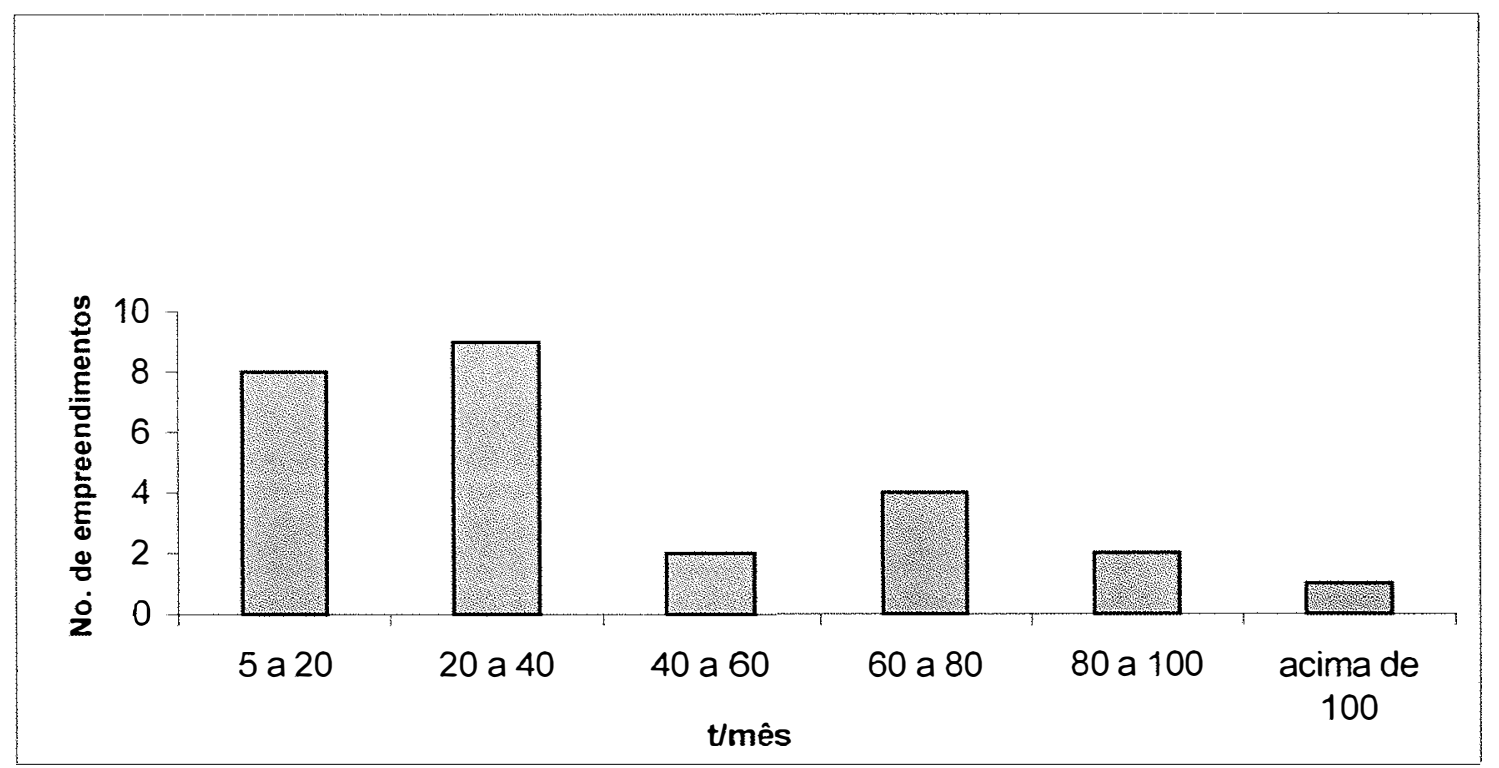

Figura 7 - Número de empreendimentos por capacidade de produção de carvão vegetal, em t/mês 
A atividade de carvão vegetal é difundida em todo o Município de Pedra Bela, todavia, existem alguns bairros rurais em que a concentração é mais intensa, que são tradicionalmente produtores de carvão vegetal, tais como os bairros do Córrego Raso, Campanha, Campestre, Boca da Mata, Limas, Pintangueiras e Tuncuns. A maioria das empresas são de pequeno e médio porte apresentando entre 10 a 20 fornos (Figura 6) e a capacidade de produção está entre 5 e 40t/mês (Figura 7)

Os fornos utilizados são do tipo encosta ou barranco, são construídos aproveitando-se a declividade dos terrenos, apresentam baixo custo e a mãode-obra para sua construção. A capacidade média dos fornos é de $4,7 \mathrm{~m}^{3}$ de lenha por ciclo de produção. Entende-se por ciclo, o periodo da colocação da lenha do forno a retirada do carvão vegetal. O ciclo médio para a produção de carvão vegetal em Pedra Bela é de 9 dias.

Conforme os dados levantados, o Município produz atualmente cerca de 1.026 t de carvão vegetal por mês, o que representa cerca de $6 \%$ de todo o carvão vegetal que circula mensalmente no Estado de São Paulo, comparado aos dados de produção total do Estado, levantado pelo Pró-Carvão (2000).

A média de produção por forno no Município é de $473 \mathrm{~kg}$ de carvão vegetal, para uma e a capacidade média de cada forno de $4,7 \mathrm{~m}^{3}$. Conclui-se que para cada $1 \mathrm{~m}^{3}$ de lenha o rendimento é de $100 \mathrm{~kg}$ de carvão vegetal. Através dessa informação pode-se estimar, portanto, que para manter sua capacidade máxima produtiva em pleno funcionamento $(1.026 \mathrm{t} / \mathrm{mês})$ são necessários cerca de $122 \mathrm{mil} \mathrm{m}^{3}$ de madeira por ano.

Dados obtidos através do Levantamento das Unidades de Produção Agrícola do Estado de São Paulo - LUPA (1996), demonstram que o Município possui cerca 2.165 hectares destinados ao cultivo de eucalipto, que apresentam uma produtiva relativamente baixa, cuja estimativa obtida junto a produtores locais está em torno de $15 \mathrm{~m}^{3} /$ ha/ano. 
Considerando-se tal produtividade de madeira e a área destinada ao cultivo de eucalipto, pode-se prever que um volume anual de madeira equivalente a $6.495 \mathrm{~m}^{3}$, considerando-se uma rotação de 5 anos para a cultura. Sendo esse tempo de rotação ( 5 anos) o período considerado suficiente para a madeira produzir um carvão que atenda os parâmetros de qualidade.

Esses dados indicam que, se o Município utilizar sua capacidade máxima instalada de produção de carvão vegetal, a área atualmente destinada ao cultivo de madeira será suficiente para abastecer somente cerca de $5 \%$ das carvoarias locais. Desse modo, a produção somente está sendo garantida em razão da madeira estar sendo buscada nos municípios vizinhos.

Tais estimativas são alarmantes, pois indicam que a falta de matériaprima pode se tornar um grande entrave para a continuidade da atividade carvoeira no Município.

Fica clara, portanto, a necessidade de investimento no reflorestamento para a continuidade da atividade no Municipio. Por tudo isso, torna-se premente a importância de investimento em políticas públicas de incentivo à atividade carvoeira visando o aumento da área florestal plantada, concomitante mente ao emprego de espécies florestais de maior produtividade e mais apropriadas para a produção de carvão vegetal.

Segundo entrevista realizada com lideranças locais, a expectativa com relação à continuidade da atividade de carvoejamento no Municipio aponta que:

"A cada dia mais a população vem conhecendo o processo de produção e a matéria-prima em função das dificuldades encontradas para outra atividade, tende ampliar sua área no decorrer dos próximos anos" (A . P. L. Prefeito Municipal) 
"A matéria-prima está ficando escassa e não há alternativas viáveis para absorver a mão-de-obra no momento" ( M. C. A. - Coordenadoria de Assistência Técnica e Integral - CATI)

"A atividade deverá continuar apesar da dificuldade de matéria-prima (florestas antigas mal manejadas), uma vez que a mão-de-obra, por herança cultural ( $3^{a}$. geração) terá dificuldades de adaptação a novas especialidades; se deixarem a atividade, poderão se transformar em auxiliar de serviços gerais ou temporários sem emprego fixo" (J. R. C. P. Programa Sistema Agroindustrial Integrado - SAI)

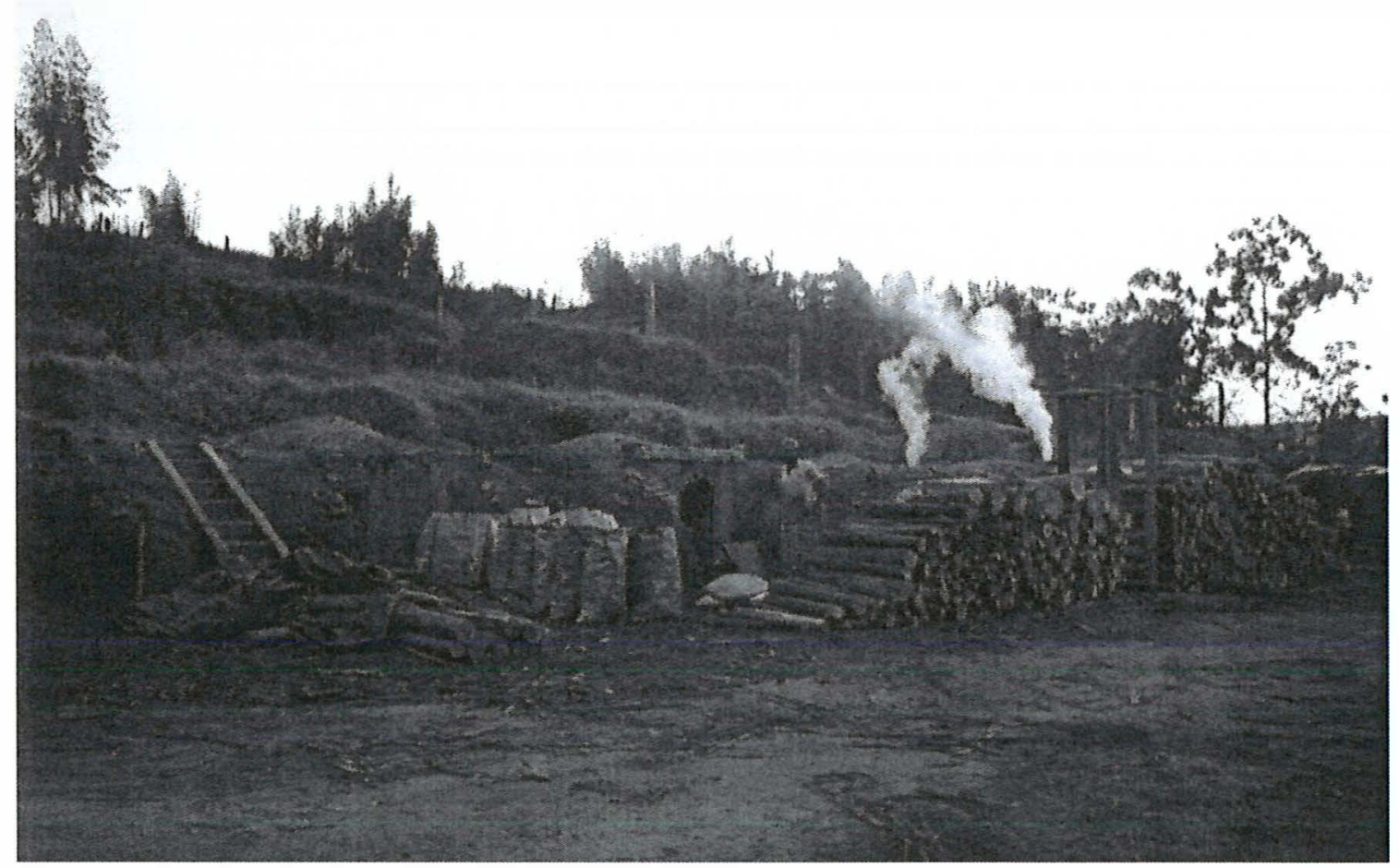

Figura 08 - Exemplo comum de carvoaria existente em Pedra Bela 


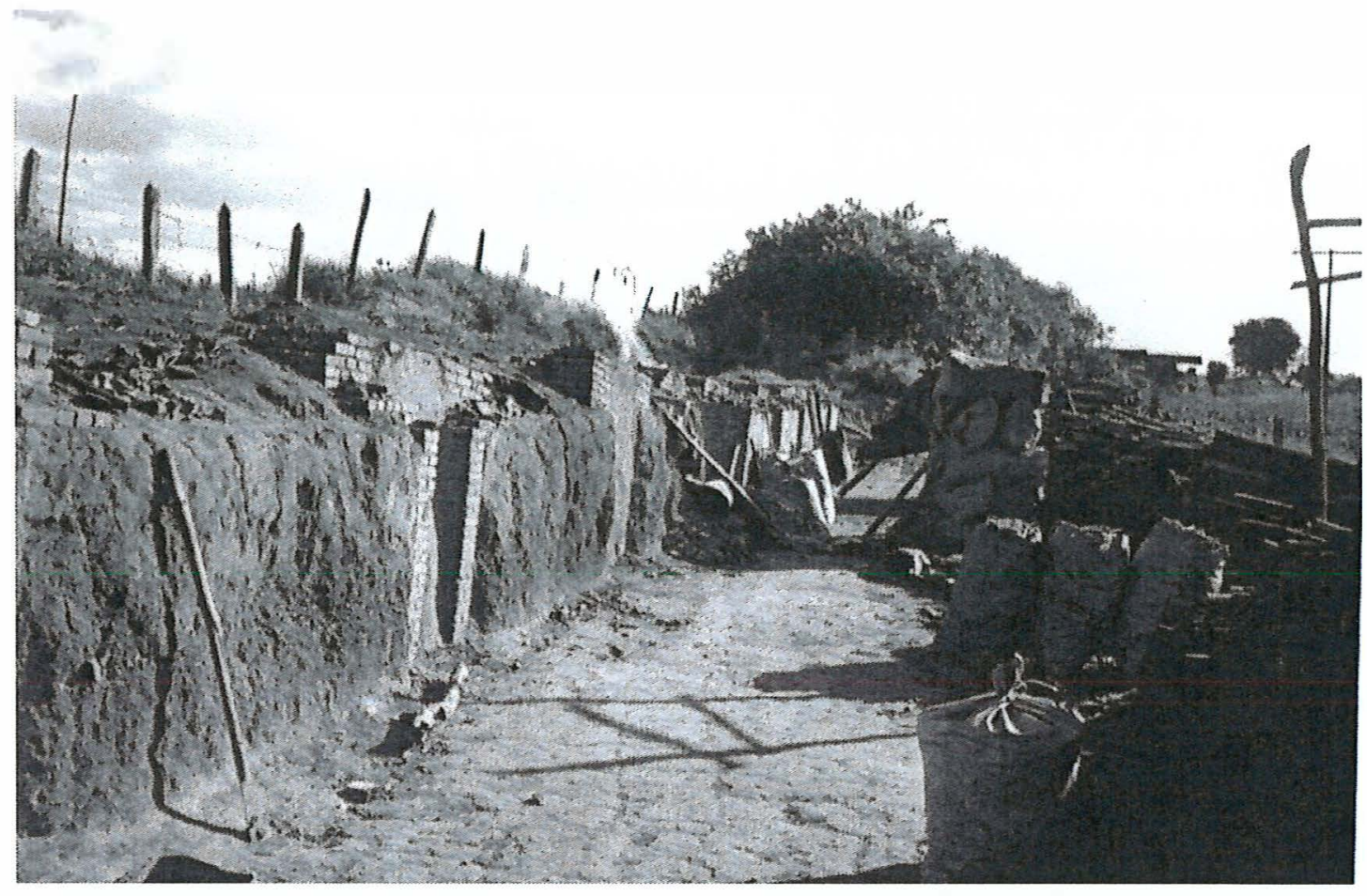

Figura 9 - Exemplo de fornos construídos em barrancos 


\subsubsection{Situação Jurídica dos Empreendimentos}

Tabela 6. Registros de CNPJ e IBAMA nos empreendimentos

\begin{tabular}{cccc}
\hline $\begin{array}{c}\text { N. do } \\
\text { empreendimento }\end{array}$ & $\begin{array}{c}\text { Atividade } \\
\text { desenvolvida }\end{array}$ & CNPJ & IBAMA \\
\hline 1 & produtor & $\mathrm{N}$ & $\mathrm{N}$ \\
2 & produtor & $\mathrm{N}$ & $\mathrm{N}$ \\
3 & produtor & $\mathrm{S}$ & $\mathrm{S}$ \\
4 & produtor & $\mathrm{S}$ & $\mathrm{N}$ \\
5 & produtor & $\mathrm{S}$ & $\mathrm{S}$ \\
6 & produtor & $\mathrm{N}$ & $\mathrm{N}$ \\
7 & produtor & $\mathrm{N}$ & $\mathrm{N}$ \\
8 & produtor & $\mathrm{N}$ & $\mathrm{N}$ \\
9 & produtor - distribuidor & $\mathrm{N}$ & $\mathrm{N}$ \\
10 & produtor & $\mathrm{N}$ & $\mathrm{N}$ \\
11 & produtor & $\mathrm{N}$ & $\mathrm{N}$ \\
12 & produtor & $\mathrm{N}$ & $\mathrm{N}$ \\
13 & produtor-distribuidor & $\mathrm{S}$ & $\mathrm{S}$ \\
14 & produtor & $\mathrm{N}$ & $\mathrm{N}$ \\
15 & produtor & $\mathrm{N}$ & $\mathrm{N}$ \\
16 & produtor - distribuidor & $\mathrm{S}$ & $\mathrm{N}$ \\
17 & produtor & $\mathrm{N}$ & $\mathrm{N}$ \\
18 & produtor & $\mathrm{S}$ & $\mathrm{S}$ \\
19 & produtor & $\mathrm{N}$ & $\mathrm{N}$ \\
20 & produtor & $\mathrm{N}$ & $\mathrm{N}$ \\
21 & produtor-distribuidor & $\mathrm{S}$ & $\mathrm{S}$ \\
22 & produtor & $\mathrm{N}$ & $\mathrm{N}$ \\
23 & produtor & $\mathrm{N}$ & $\mathrm{N}$ \\
24 & produtor-distribuidor & $\mathrm{S}$ & $\mathrm{S}$ \\
25 & produtor & $\mathrm{N}$ & $\mathrm{N}$ \\
26 & intermediário & $\mathrm{N}$ & $\mathrm{N}$ \\
27 & intermediário & $\mathrm{N}$ & $\mathrm{N}$ \\
28 & & $\mathrm{~N}$ \\
\hline
\end{tabular}

$\mathrm{S}=\operatorname{sim} \mathrm{N}=$ não

Conforme demonstrado na Tabela 6 e na Figura 10, a situação jurídica dos empreendimentos está muito ligada ao tipo de atividade exercida. Nota-se que a maioria dos produtores-distribuidores $(80 \%)$ possuem registro no IBAMA e CNPJ. A maioria dos produtores, no entanto, atuam na informalidade, sendo que apenas 19\% desses apresentam registro de CNPJ e 14\% apresentam IBAMA. Nenhum dos intermediários apresentam registro no IBAMA ou CNPJ. 


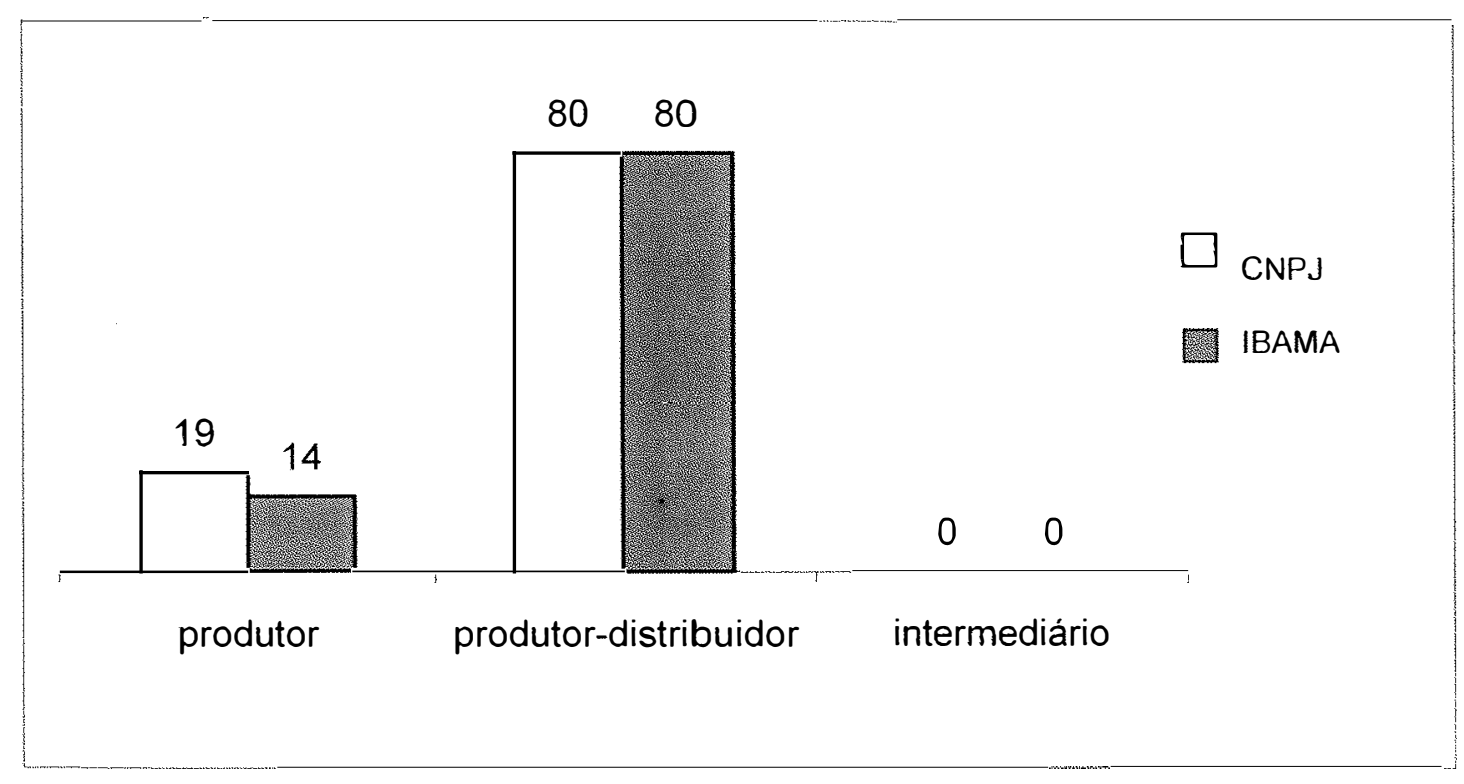

Figura 10 - Percentual dos empreendimentos que possuem CNPJ e IBAMA

\subsubsection{Matéria-prima}

Apesar do carvão vegetal ser uma das principais atividades nas propriedades rurais a matéria-prima, não é em sua maioria, oriunda da própria propriedade, onde a atividade é exercida, conforme descrito na Tabela 7. 
Tabela 7 - Dados básicos sobre matéria-prima utilizada nos empreendimentos de carvão vegetal

\begin{tabular}{|c|c|c|c|c|}
\hline \multirow{2}{*}{$\begin{array}{c}\text { No. do } \\
\text { empreendimento }\end{array}$} & \multicolumn{4}{|c|}{ Matéria-prima } \\
\hline & Espécie & Procedência & Origem & ${ }^{\star}$ Custo $\left(\mathrm{R} \$ / \mathrm{m}^{3}\right)$ \\
\hline 1 & Eucalyptus & Pedra Bela & $\frac{P}{P}$ & 15 \\
\hline 2 & Eucalyptus & Pedra Bela & $\mathrm{P} / \mathrm{T}$ & 18 \\
\hline 3 & Eucalyptus & Pedra Bela & $\mathrm{P}$ & 18 \\
\hline 4 & Eucalyptus & Pedra Bela & $\mathrm{P} / \mathrm{T}$ & 18 \\
\hline 5 & Eucalyptus & Pedra Bela & $\mathrm{T}$ & 18 \\
\hline 6 & Eucalyptus & Pedra Bela & $\mathrm{T}$ & 16 \\
\hline 7 & Eucalyptus & Pedra Bela & $P$ & 17 \\
\hline 8 & Eucalyptus & Pedra Bela & $\mathrm{T}$ & 18 \\
\hline 9 & Eucalyptus & Pedra Bela & $P$ & 17 \\
\hline 10 & Eucalyptus & Pedra Bela e Minas Gerais & $\mathrm{T}$ & 18 \\
\hline 11 & Eucalyptus & Pedra Bela & $P$ & 17 \\
\hline 12 & Eucalyptus & Bragança Paulista & $\mathrm{T}$ & 18 \\
\hline 13 & Eucalyptus & Pinhalzinho & $\mathrm{P} / \mathrm{T}$ & 18 \\
\hline 14 & Eucalyptus & Pedra Bela & $P$ & 20 \\
\hline 15 & Eucalyptus & Pedra Bela & $\mathrm{P} / \mathrm{T}$ & 17 \\
\hline & & Bragança Paulista e Pedra & & \\
\hline 16 & Eucalyptus & Bela & $\mathrm{P} / \mathrm{T}$ & 17 \\
\hline 17 & Eucalyptus & Bragança Paulista & $\mathrm{P} / \mathrm{T}$ & 18 \\
\hline 18 & Eucalyptus & Pedra Bela & $T$ & 18 \\
\hline 19 & Eucalyptus & Pedra Bela & $\mathrm{T}$ & 17 \\
\hline 20 & Eucalyptus & Pedra Bela & $\mathrm{T}$ & 18 \\
\hline 21 & Eucalyptus & Pedra Bela & $\mathrm{P} / \mathrm{T}$ & 19 \\
\hline 22 & Eucalyptus & Pedra Bela & $\mathrm{T}$ & 18 \\
\hline 23 & Eucalyptus & Socorro & $\mathrm{T}$ & 18 \\
\hline 24 & Eucalyptus & Pedra Bela & $P$ & 20 \\
\hline 25 & Eucalyptus & Pedra Bela & $P$ & 15 \\
\hline 26 & Eucalyptus & Pedra Bela & $P$ & 18 \\
\hline Média & & & & 18 \\
\hline
\end{tabular}

* madeira posta na boca do forno, em $\mathrm{R} \$$ por $\mathrm{m}^{3}$ estéreo.

$\mathrm{P}=$ matéria prima própria $\quad \mathrm{T}=$ matéria-prima adquirida junto à terceiros 


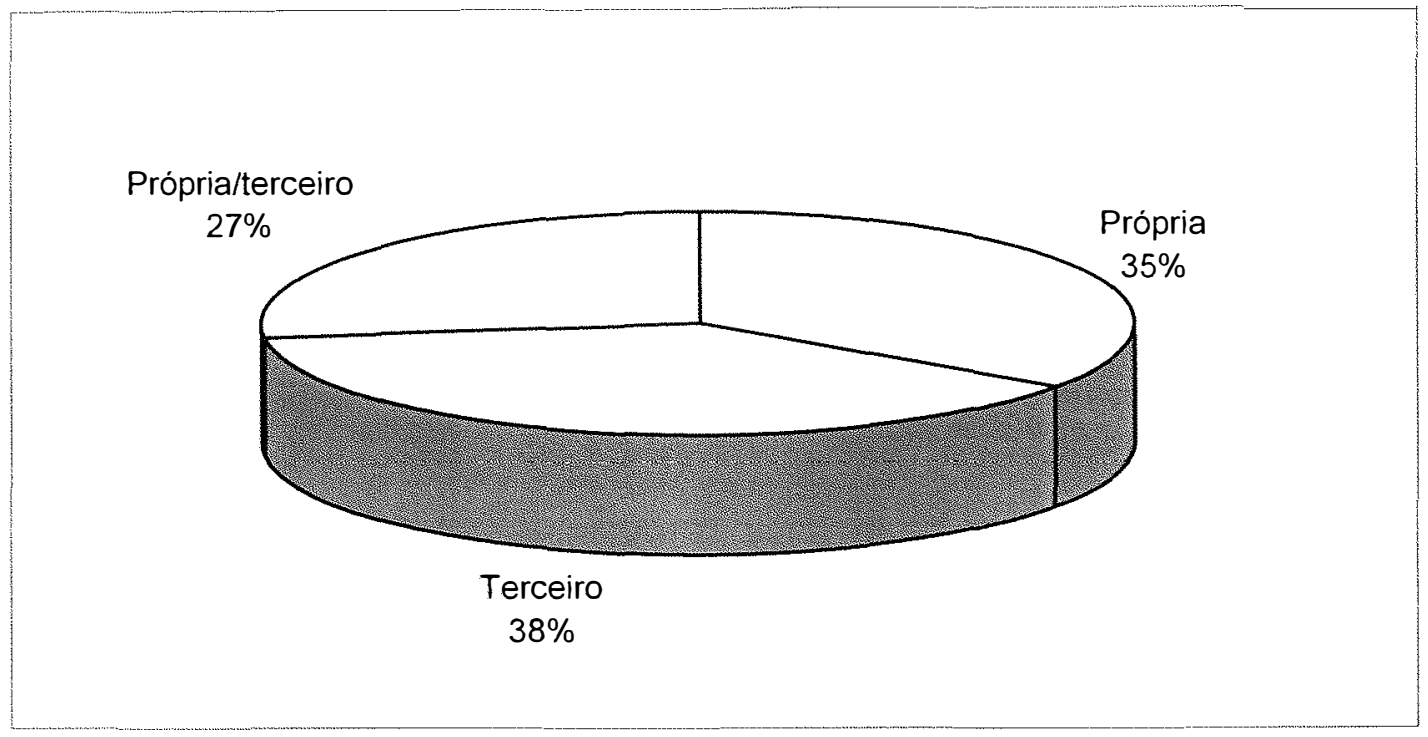

Figura 11 - Origem da matéria-prima utilizada nos empreendimentos

Todas as empresas utilizam a madeira plantada para fins comerciais, sendo o gênero eucalipto predominantemente utilizado pelos produtores de carvão vegetal da região.

A madeira é atualmente comercializada a um preço médio de $\mathrm{R} \$ 18$ por $\mathrm{m}^{3}$ estéreo, pronta para ser carbonizado e posta na boca do forno. O preço da madeira adquirida em pé varia de $R \$ 4,00$ a $R \$ 7,00$ o $\mathrm{m}^{3}$.

O eucalipto é a espécie predominantemente utilizada na região, pois além de ser a madeira mais disponivel, oferece vantagens em termos da qualidade do carvão vegetal produzido. Segundo os produtores de carvão vegetal, o melhor carvão é o proveniente do "eucalipto roxo" (Eucalyptus saligna) por originar carvão denso e de boa aceitação no mercado. Existe também na região o que os produtores chamam de "eucalipto vermelho" (Eucalyptus urophylla), que segundo os moradores é uma madeira razoável, só que não tão aceito quanto o primeiro.

Com a existência de plantios florestais por empresas de papel e celulose na região, foi introduzido o que os moradores denominaram de "eucalipto rolha" 
(Eucalyptus uro-grandis) que tem apresentado baixa densidade e rendimento , sendo considerados impróprios para a produção de carvão vegetal.

A procedência da matéria-prima encontra-se no Município de Pedra Bela e cidades de entorno. Os maiores proprietários possuem plantios próprios e alguns deles estão investindo na reposição de suas florestas. Todavia, nota-se que, principalmente, os pequenos produtores que não dispõem de recursos e muito pouco ou nada investem na reforma, reposição ou em qualquer prática de manejo em suas florestas a cada rotação vem apresentando um decrescente volume de madeira por hectare. 


\subsubsection{Embalagem do Carvão Vegetal}

Tabela 8. Dados sobre embalagem do carvão vegetal no Município

\begin{tabular}{|c|c|c|c|}
\hline No. do empreendimento & Tipo de embalagem & Procedência da embalagem & Peso médio (kg) \\
\hline 1 & $\mathrm{R}$ & São Paulo & 20 \\
\hline 2 & $\mathrm{R}$ & São Paulo & 22 \\
\hline 3 & $\mathrm{R}$ & comprador & 20 \\
\hline 4 & $\mathrm{R}$ & Itapeva & 10 e 20 \\
\hline 5 & $\mathrm{R}$ & comprador & 22 \\
\hline 6 & $\mathrm{R}$ & comprador & 22 \\
\hline 7 & $\mathrm{R}$ & comprador & 20 \\
\hline 8 & $\mathrm{R}$ & comprador & 25 \\
\hline 9 & $\mathrm{R}$ e $\mathrm{P}$ & São Paulo & $3 ; 4 ; 6 ;$ e 22 \\
\hline 10 & $\mathrm{R}$ & São Paulo & 20 \\
\hline 11 & $\mathrm{R}$ & comprador & 20 \\
\hline 12 & $R$ e $P$ & Louveira & 2,$5 ; 4$ e 20 \\
\hline 13 & $\mathrm{R}$ & comprador & 22 \\
\hline 14 & $\mathrm{R}$ & São Paulo & 22 \\
\hline 15 & $\mathrm{R}$ & São Paulo & 20 \\
\hline 16 & $\mathrm{P}$ & Campinas & 2,$5 ; 3$ e 4 \\
\hline 17 & $\mathrm{R}$ & São Paulo & 20 \\
\hline 18 & $P$ e $R$ & comprador & 3,6 e 23 \\
\hline 19 & $\mathrm{R}$ & comprador & 20 \\
\hline 20 & $\mathrm{R}$ & comprador & 20 \\
\hline 21 & $\mathrm{P}$ & comprador & $3 ; 5 ; 7 ; 10$ e 12 \\
\hline 22 & $\mathrm{R}$ & comprador & 22 \\
\hline 23 & $\mathrm{R}$ & São Paulo & 25 \\
\hline 24 & $\mathrm{P}$ & São Paulo & 3 e 7 \\
\hline 25 & $\mathrm{R}$ & comprador & 20 \\
\hline 26 & $\mathrm{R}$ & comprador & 20 \\
\hline 27 & $\mathrm{P}$ & Campinas e São Paulo & 2,2 e 2,5 \\
\hline 28 & $\mathrm{P}$ e R & comprador & 3 e 10 \\
\hline
\end{tabular}

$\mathrm{P}=$ papel $\mathrm{R}=$ ráfia 


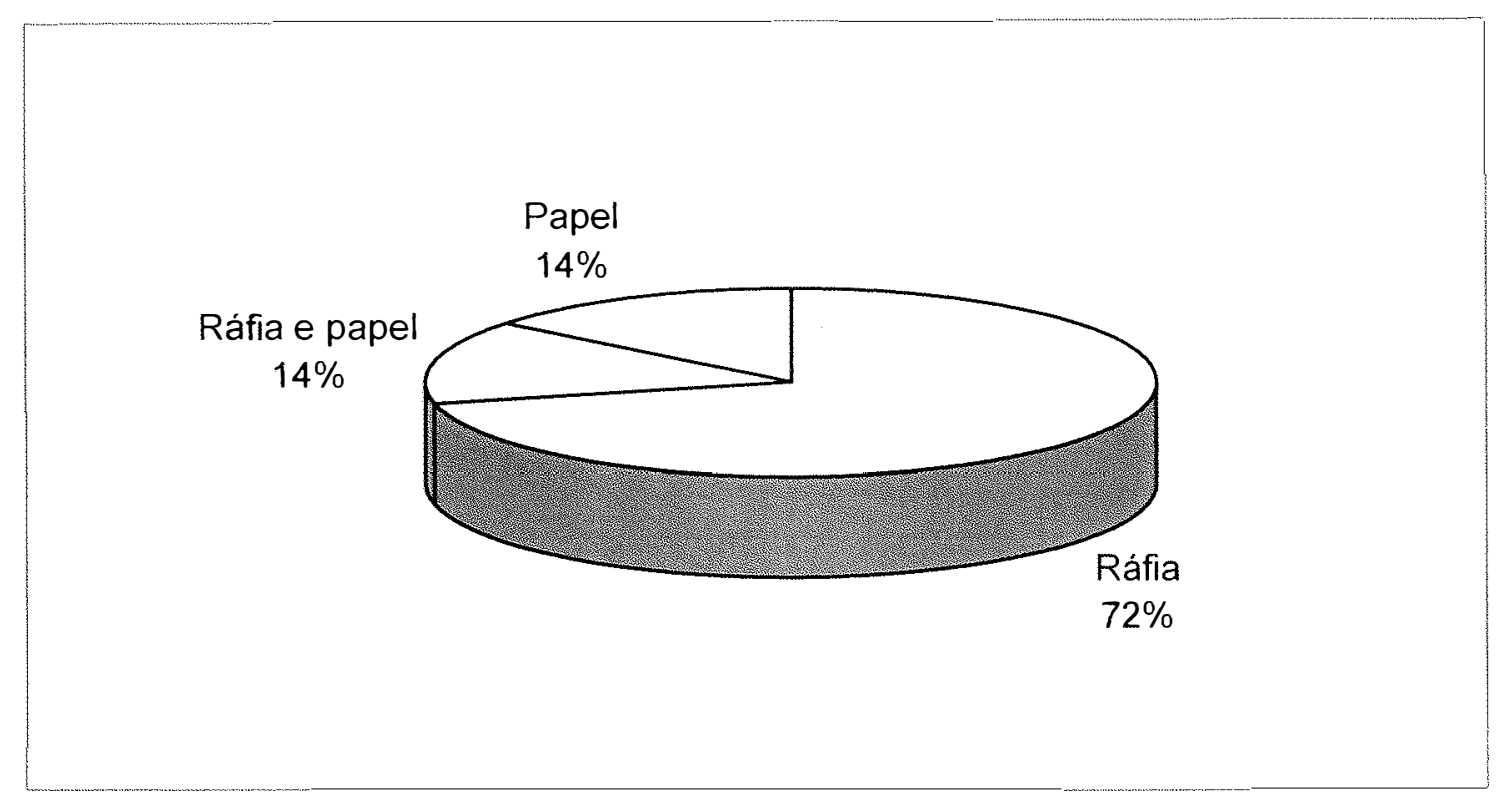

Figura 12 - Tipo de embalagem utilizada para o carvão vegetal

A maioria dos empreendimentos $(72 \%)$ utilizam sacos de ráfia de $20 \mathrm{~kg}$ para a embalar o carvão. Dessas cerca de $82 \%$ reutilizam as mesmas embalagens diversas vezes, principalmente para minimizar custos com as suas aquisições. Detectou-se, entretanto, que uma das empresas analisadas reutiliza embalagens de agrotóxico, o que pode resultar em efeitos danosos aos trabalhadores que efetuam o empacotamento e manuseiam a embalagem e aos consumidores desse produto.

Existem na região algumas empresas (14\%) que, por exercerem a atividade de produtores e distribuidores de carvão vegetal, utilizam tanto o saco de ráfia quanto o saco de papel. A maioria dos empreendimentos adquirem a embalagem do responsável pela compra do carvão vegetal. 


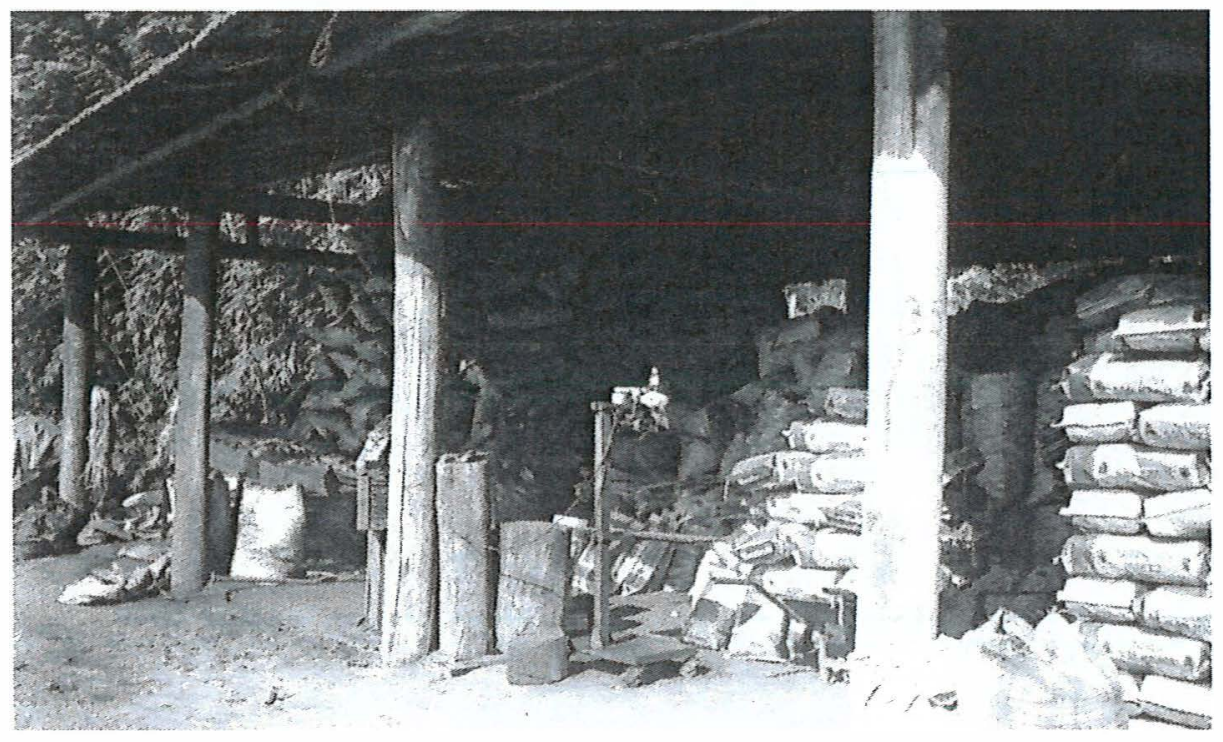

Figura 13 - Exemplo de armazenamento do carvão vegetal no Município de Pedra Bela - SP

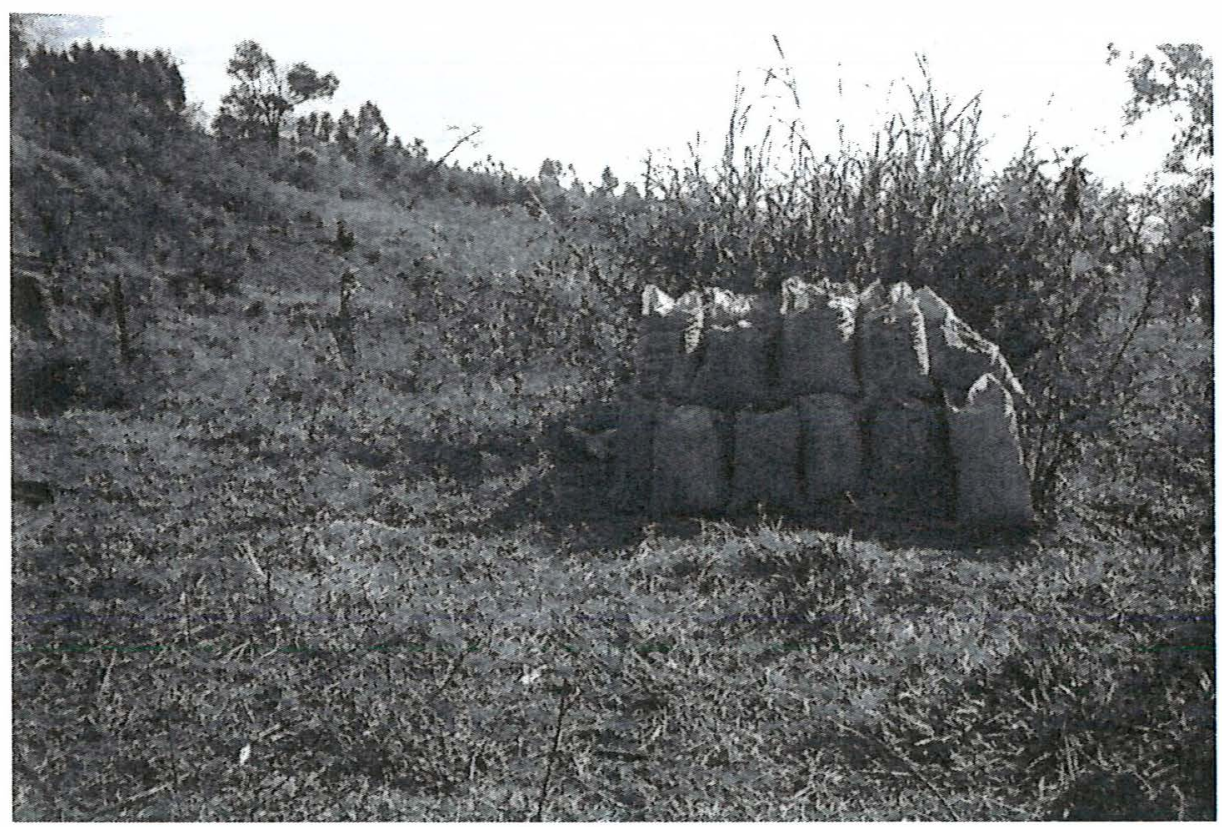

Figura 14 - Exemplo de embalagem em saco de ráfia e armazenamento à céu aberto

Cerca de $32 \%$ não possui galpão para armazenamento do carvão, que fica exposto elou coberto com lona plástica até ser transportado, o que torna o 
carvão susceptível à umidade o que pode dificultar seu acendimento e comprometer a qualidade do produto (Figuras 14).

\subsubsection{Equipamentos e Infra-estrutura}

Tabela 9. Dados sobre infra-estrutura e equipamentos existentes nos empreendimentos

\begin{tabular}{|c|c|c|c|c|c|c|c|c|c|}
\hline \multirow{2}{*}{$\begin{array}{l}\text { No. do } \\
\text { empreen } \\
\text { dimento }\end{array}$} & \multicolumn{9}{|c|}{ Infra-estrutura e equipamentos } \\
\hline & $\begin{array}{l}\text { Máquina de } \\
\text { costura }\end{array}$ & $\begin{array}{l}\text { Peneira } \\
\text { elétrica }\end{array}$ & Balança & Galpão & Escritório & $\begin{array}{l}\text { Energia } \\
\text { elétrica }\end{array}$ & $\begin{array}{l}\text { Instalação } \\
\text { sanitária }\end{array}$ & $\begin{array}{l}\text { Água } \\
\text { potável }\end{array}$ & EPI \\
\hline 1 & $\mathrm{~N}$ & $\mathrm{~N}$ & $\mathrm{~N}$ & S & $\mathrm{N}$ & $\mathrm{N}$ & $\mathrm{N}$ & $\mathrm{S}$ & $\mathrm{S}$ \\
\hline 2 & $\mathrm{~N}$ & $\mathrm{~N}$ & $\mathrm{~N}$ & $\mathrm{~N}$ & $\mathrm{~N}$ & $S$ & $S$ & $S$ & S \\
\hline 3 & $\mathrm{~N}$ & $\mathrm{~N}$ & $\mathrm{~N}$ & $S$ & $S$ & $S$ & $S$ & $S$ & $S$ \\
\hline 4 & $S$ & S & S & $S$ & $\mathrm{~N}$ & $\mathrm{~N}$ & $\mathrm{~S}$ & $\mathrm{~S}$ & $N$ \\
\hline 5 & $\mathrm{~N}$ & $\mathrm{~N}$ & $\mathrm{~N}$ & $\mathrm{~N}$ & $\mathrm{~N}$ & $\mathrm{~S}$ & $\mathrm{~S}$ & $S$ & $\mathrm{~S}$ \\
\hline 6 & $N$ & $\mathrm{~N}$ & $\mathrm{~N}$ & $\mathrm{~N}$ & $\mathrm{~N}$ & $\mathrm{~S}$ & S & $S$ & $\mathrm{~N}$ \\
\hline 7 & $N$ & $\mathrm{~N}$ & $\mathrm{~N}$ & $S$ & $\mathrm{~N}$ & $N$ & $S$ & $S$ & $S$ \\
\hline 8 & $S$ & $S$ & $S$ & $S$ & $N$ & $S$ & $S$ & $S$ & $S$ \\
\hline 9 & $\mathrm{~N}$ & $\mathrm{~N}$ & $N$ & $S$ & $\mathrm{~N}$ & $\mathrm{~N}$ & $\mathrm{~N}$ & $S$ & $S$ \\
\hline 10 & $\mathrm{~N}$ & $\mathrm{~N}$ & $\mathrm{~N}$ & $N$ & $\mathrm{~N}$ & $\mathrm{~N}$ & $\mathrm{~N}$ & $S$ & $\mathrm{~S}$ \\
\hline 11 & $N$ & $N$ & $N$ & $N$ & $N$ & $\mathrm{~S}$ & $S$ & $S$ & $N$ \\
\hline 12 & $S$ & $S$ & $\mathrm{~N}$ & $S$ & $\mathrm{~N}$ & $\mathrm{~S}$ & $S$ & $S$ & $\mathrm{~N}$ \\
\hline 13 & $N$ & $\mathrm{~N}$ & $\mathrm{~N}$ & $S$ & $N$ & $N$ & $\mathrm{~N}$ & $S$ & $S$ \\
\hline 14 & $S$ & $S$ & $S$ & $S$ & $N$ & $N$ & $S$ & $S$ & $\mathrm{~S}$ \\
\hline 15 & $\mathrm{~N}$ & $N$ & $N$ & $S$ & $N$ & $\mathrm{~N}$ & $S$ & $S$ & $S$ \\
\hline 16 & $S$ & $S$ & $S$ & $S$ & $\mathrm{~N}$ & $S$ & $S$ & $S$ & $\mathrm{~S}$ \\
\hline 17 & $\mathrm{~N}$ & $\mathrm{~N}$ & $\mathrm{~N}$ & $\mathrm{~S}$ & $\mathrm{~N}$ & $\mathrm{~N}$ & $S$ & $S$ & $\mathrm{~S}$ \\
\hline 18 & $\mathrm{~S}$ & $S$ & $S$ & $S$ & $\mathrm{~N}$ & $S$ & $S$ & $S$ & $N$ \\
\hline 19 & $N$ & $N$ & $N$ & $\mathrm{~N}$ & $N$ & $\mathrm{~S}$ & $S$ & $\mathrm{~S}$ & $\mathrm{~S}$ \\
\hline 20 & $\mathrm{~N}$ & $N$ & $N$ & $S$ & $N$ & $\mathrm{~N}$ & $S$ & $S$ & $\mathrm{~S}$ \\
\hline 21 & $\mathrm{~S}$ & $S$ & $S$ & $\mathrm{~S}$ & $S$ & $S$ & $S$ & $\mathrm{~S}$ & $\mathrm{~S}$ \\
\hline 22 & $N$ & $N$ & $N$ & $N$ & $N$ & $S$ & $S$ & $S$ & $N$ \\
\hline 23 & $\mathrm{~N}$ & $\mathrm{~N}$ & $\mathrm{~N}$ & $\mathrm{~N}$ & $\mathrm{~N}$ & $\mathrm{~N}$ & $S$ & $S$ & $\mathrm{~N}$ \\
\hline 24 & $S$ & $S$ & $S$ & $S$ & $S$ & $S$ & $S$ & $S$ & $S$ \\
\hline 25 & $N$ & $\mathrm{~N}$ & $\mathrm{~N}$ & $S$ & $\mathrm{~N}$ & $N$ & $\mathrm{~S}$ & $S$ & $S$ \\
\hline 26 & $\mathrm{~N}$ & $\mathrm{~N}$ & $\mathrm{~N}$ & $\mathrm{~N}$ & $N$ & $\mathrm{~N}$ & $\mathrm{~S}$ & $\mathrm{~S}$ & $\mathrm{~S}$ \\
\hline 27 & $S$ & $S$ & $S$ & $S$ & $\mathrm{~N}$ & $\mathrm{~N}$ & $N$ & $S$ & $S$ \\
\hline 28 & $N$ & $S$ & $\mathrm{~N}$ & $S$ & $N$ & $S$ & $S$ & $S$ & $S$ \\
\hline
\end{tabular}

\footnotetext{
$\mathrm{N}=$ não $\mathrm{S}=\operatorname{sim}$
} 


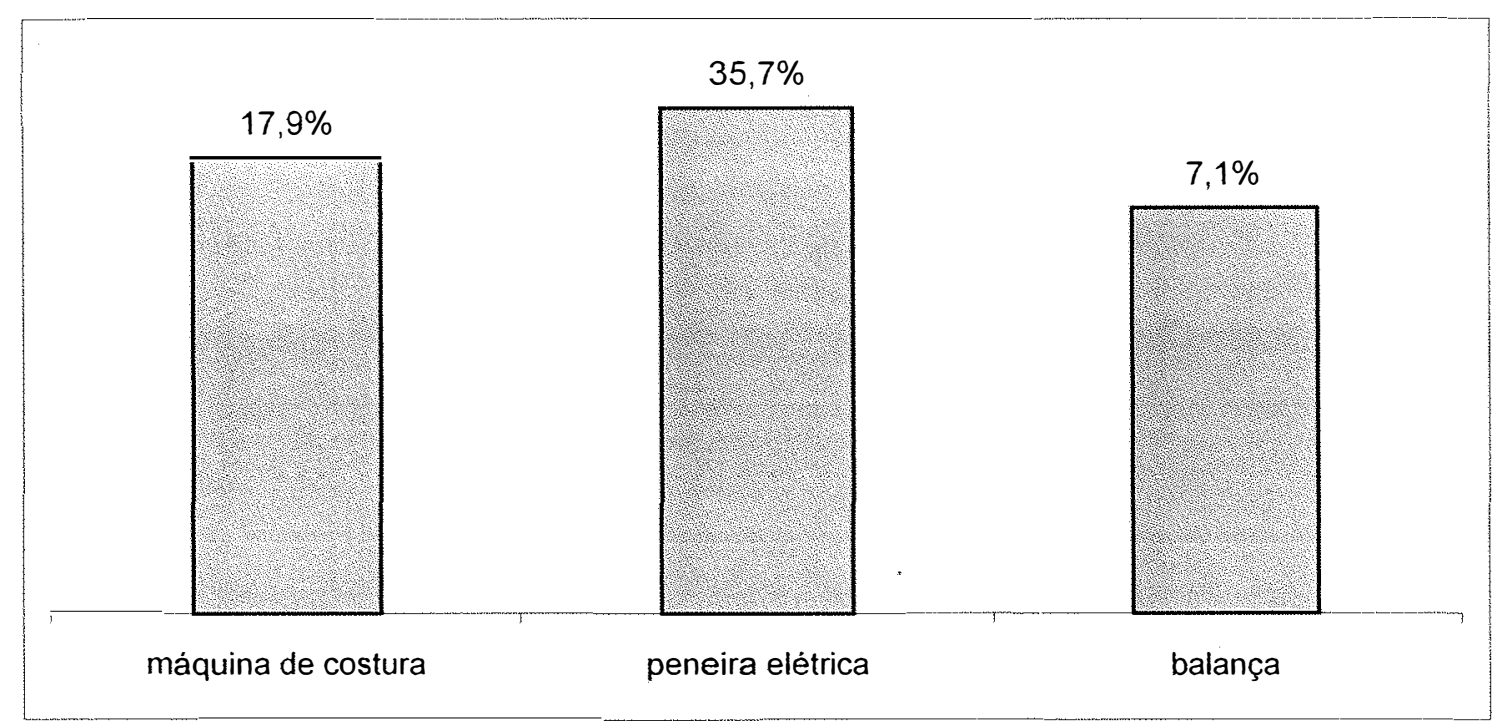

Figura 15 - Equipamentos existentes nas propriedades ligadas à atividade de carvão vegetal

A produção e o processamento de carvão vegetal em Pedra Bela é tradicional e as técnicas que vêm sendo utilizadas são as mesmas à décadas. A maioria do processo é artesanal e cerca de um terço das empresas possuem peneira elétrica, algumas adquiriram a máquina de costura elétrica e balança para o processo de embalagem do carvão vegetal.

Cerca de 3 empreendimentos ( $9 \%$ do total) estão adotando o sistema de fornos cobertos com telhado de alvenaria, pois segundo produtores tal cobertura apresenta as seguintes vantagens:

- favorece a produção, pois os funcionários trabalham mesmo com a chuva;

- a madeira permanece seca, facilitando a carbonização;

- aumenta a durabilidade dos fornos;

- diminui desperdícios e gastos de produção. 


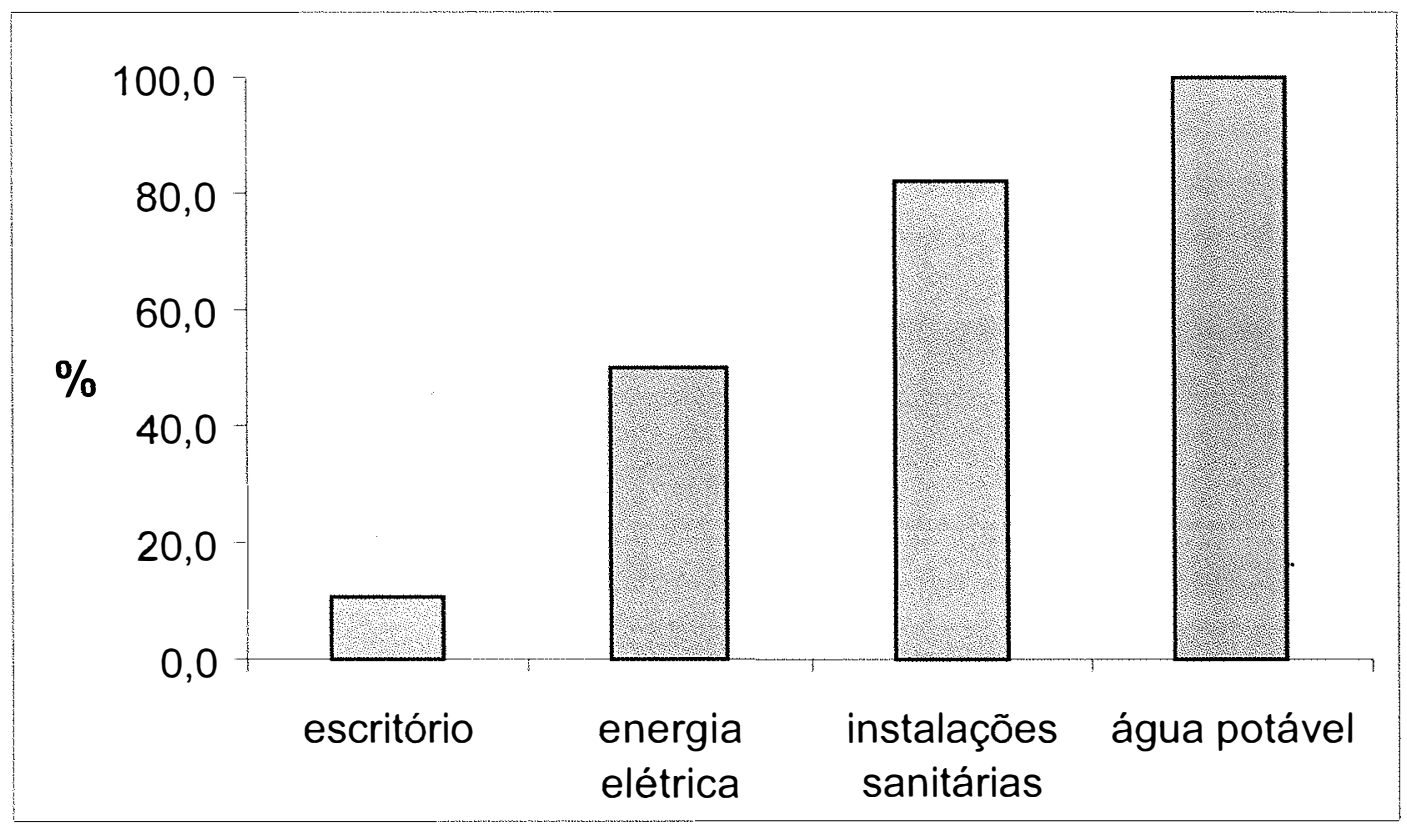

Figura 16 - Infra-estrutura existente nas propriedades

Segundo os moradores, em todas as propriedades existe a água potável e esta é proveniente de poços cavados nas propriedades (Figura 16). Todavia, a água consumida nas propriedades apesar de ser considerada potável pelos seus consumidores, não recebe nenhum tipo de tratamento.

A maioria dos empreendimentos de carvão vegetal, principalmente por estarem localizadas próximas as moradias, possuem energia elétrica e instalação sanitária, todavia, o esgoto é lançado em fossas secas e/ou a céu aberto, uma vez que não há saneamento básico nesses locais.

Conforme entrevista realizada com lideranças locais, existem no Município algumas iniciativas para incentivo à atividade de carvoejamento tais como:

"- Distribuição de mudas gratuitas para a reposição florestal

- Equipamento para preparo da terra, subsidiado pela prefeitura;

- Aquisição do equipamento para embalagem do produto; 
- Apoio à formação de cooperativas;

- Transporte gratuito aos produtores para conhecerem novos sistemas de produção" (A . P. L. Prefeito Municipal)

"O PRONAF poderá oferecer infra-estrutura, tais como a aquisição de máquinas e equipamentos para processamento e embalamento do carvão, e através do Programa SAl, com a organização rural e comercialização e tecnologia"( M. C. A. - CATI)

"Existe atualmente um projeto para embalagem e processamento em galpão e ser cedido pela Prefeitura, através do Programa Nacional de Agricultura Familiar - PRONAF; Programa Sistema Agroindustrial Integrado SAI, por meio de um convênio da Secretaria de Agricultura e SEBRAE, voltada para o fomento de plantio de novas florestas, reforma das antigas, atividades agrosilvipastoris, utilização da folhagem para extração de óleos, descoberta e exploração de nichos de mercado e utilização de resíduos" (J. R. C. P. Programa SAI) 


\subsubsection{Equipamentos de Segurança}

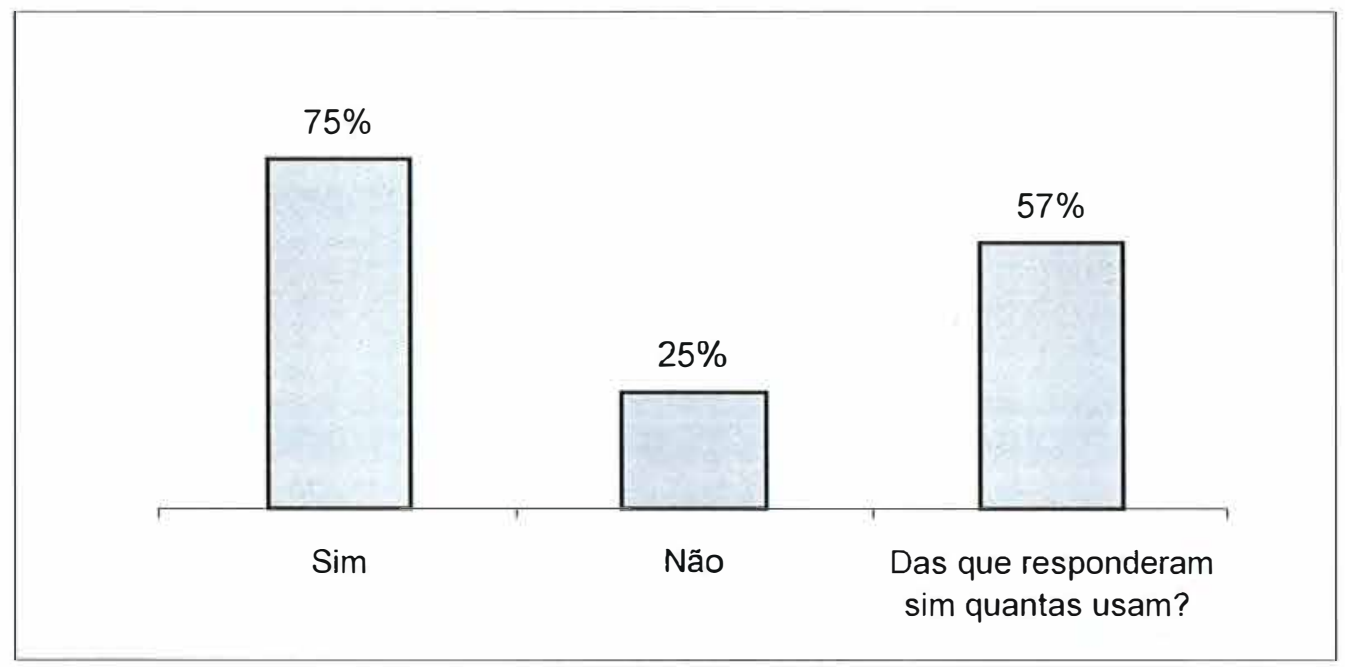

Figura 17 - Utilização de equipamento de proteção individual (EPI) na propriedades

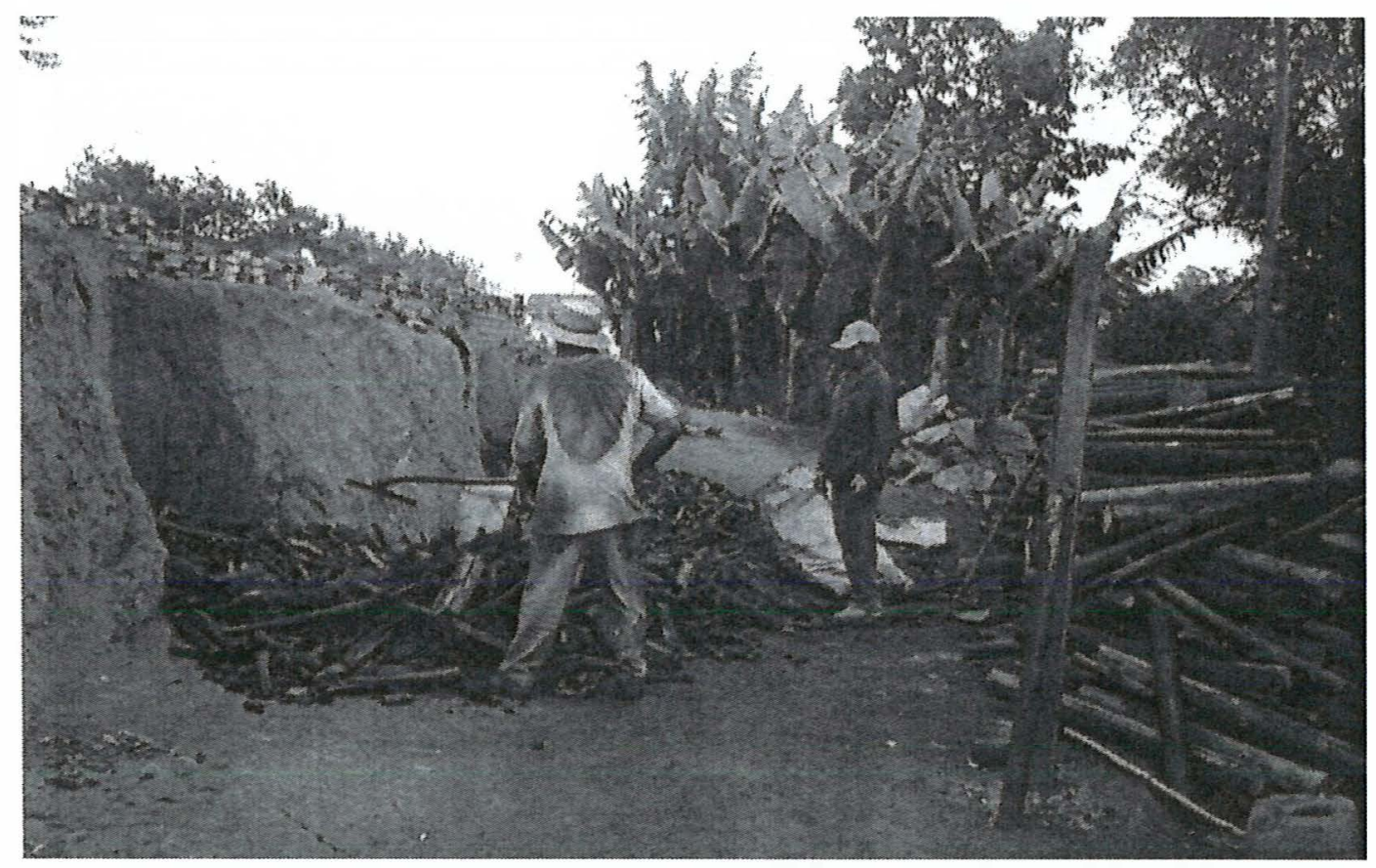

Figura 18 - Exemplo das condições de trabalho nas pequenas propriedades de produção de carvão vegetal do Município de Pedra Bela - SP 
A maior parte dos estabelecimentos possui equipamento de segurança básico, constituído por botas, luvas e máscaras. Muitos proprietários explicitaram a preocupação com a utilização de tais equipamentos, especialmente devido as cobrança dos órgãos legais, que podem aplicar penalidades e multas aos proprietários. Todavia, significativo número de funcionários (Figura 17) não utilizam o equipamento de proteção individual no trabalho, argumentando desconforto e declínio de rendimento quando tais equipamentos são utilizados. Isto ocorre principalmente com relação a máscara que, segundo os mesmos, torna-se insuportável dado ao forte calor nos fornos e as luvas dificultam o manuseio do carvão (Figura 18).

Notou-se que o maior entrave não é a aquisição desses equipamentos, uma vez que a maioria das empresas os possuem, todavia o que os seus usuários reclamam é a falta de adequação dos mesmos ao tipo de atividade que desenvolvem. Os equipamentos utilizados nessas propriedades são os mesmos utilizados em outros tipos de empresas. Os trabalhadores explicitaram a necessidade do desenvolvimento de equipamentos de proteção individual adaptados às suas realidades de trabalho.

\subsubsection{Aproveitamento de Sub-produtos da Atividade Carvoeira}

Dos empreendimentos estudados apenas um realiza a extração do licor pirolenhoso, que é uma fração aquosa obtida da condensação da fumaça emitida da carbonização, constituído de pelo menos $80 \%$ de água e de variados componentes químicos, tais como o ácido acético, o álcool metílico e a acetona.

A extração do licor constitui-se uma forma de aproveitamento dos gases gerados com a carbonização, para agregação de maior valor a atividade. Segundo o empreendimento que realiza o aproveitamento do licor pirolenhoso (cerca de 50 litros/semana), o produto é comercializado para um produtor de 
agricultura orgânica de São Paulo, que utiliza o produto para o controle de pragas e insetos em sua propriedade.

\subsection{Aspectos Sócio-Econômicos}

As Tabelas de 10 e 11 apresentam os resultados dos estudos referentes à mão-de-obra, remuneração e comercialização observados junto à atividade de produção de carvão vegetal em Pedra Bela. As Figuras de 19 a 21 apresentam ilustrações complementares sobre tais aspectos. 


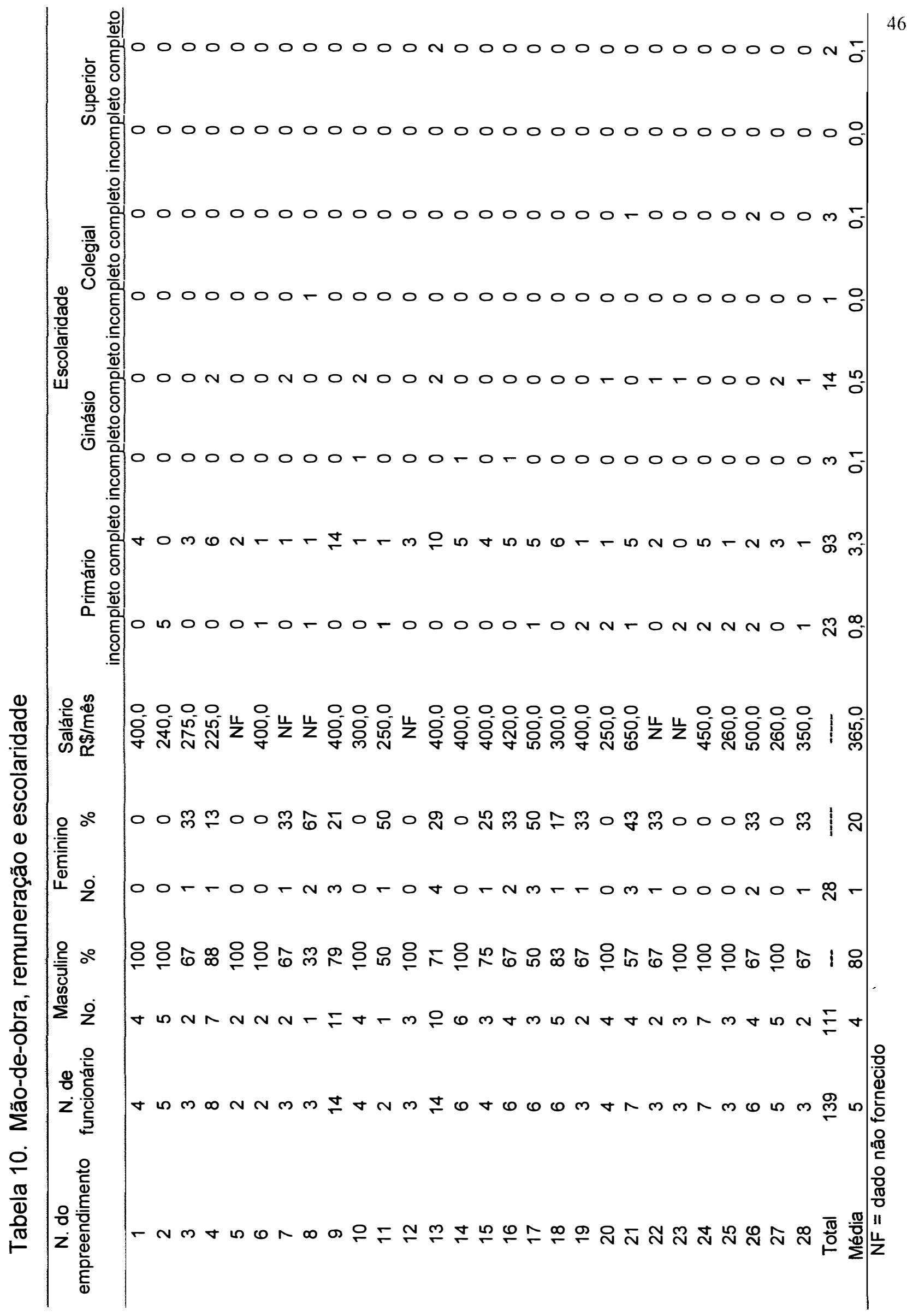


A maioria das empresas é mantida por membros da própria família, vizinhos e funcionários temporários. Os empreendimentos apresentam em média menos de 5 funcionários.

Cerca de 139 pessoas no Município estão diretamente ligados ao carvoejamento e desempenham atividades de controle de produção junto aos fornos (enchimento dos fornos e retirada do carvão) e de beneficiamento do produto (peneiramento, embalo e costura). Considerando-se que para cada um desses funcionários existem outros cerca de seis dependentes, pode-se estimar que mais de 800 pessoas necessitam da atividade de carvoejamento para sobreviver, o que representa cerca de $20 \%$ da população rural do Município. Não estão computados os funcionários envolvidos na retirada da matéria-prima e no transporte do carvão, que muitas vezes, são terceirizados e que por isto, não foi possivel de serem incluídos neste estudo.

As lideranças locais demonstram a importância da atividade carvoeira no Município, conforme depoimento abaixo:

"Hoje ela ocupa 50\% da mão-de-obra na zona rural do Município, ela detém os melhores salários do campo e permite a muitos assalariados após um período a terem seus próprios negócios, uma vez que o capital inicial é pequeno" (A. P. L. Prefeito Municipal)

"A atividade é de fundamental importância para o Município poiș, emprega aproximadamente $25 \%$ da população do Município em sua cadeia produtiva" (M. C. A. - CATI)

"A importância é primordial, pois 40\% da população rural (cerca de 2.000 habitantes) dependem economicamente da produção do carvão" (J. R. C. P. Programa SAl) 
Cerca de $20 \%$ da mão-de-obra para o carvoejamento no Município é feminina e, geralmente, está ligada ao beneficiamento do carvão, tais como o empacotamento e a costura das embalagens. Foram constatadas duas propriedades onde as mulheres auxiliam também na retirada da lenha e no trabalho junto aos fornos.

Todos os filhos com idade de até 14 anos das famílias entrevistadas, encontram-se regularmente matriculados em escolas do Município. Conforme recente portaria da Secretaria de Inspeção do Trabalho no. 06 , de 05 de fevereiro de 2001, embasada no artigo 405 da Consolidação das Leis do Trabalho - CLT, aprovada pelo Decreto-Lei n. ${ }^{\circ} 5.452$, de $1^{\circ}$ de maio de 1943 , que considera que o trabalho do menor de 18 (dezoito) anos fica proibido nas atividades classificadas como serviços perigosos ou insalubres, o que pode ser atribuído aos trabalhos em carvoaria. Verificou-se nas carvoarias de Pedra Bela, somente um menor de 18 anos exercendo atividade na área. A grande maioria situa-se entre 18 a 65 anos

Constatou-se que $100 \%$ dos empreendimentos não apresentam mãode-obra infantil. Todavia, pode-se observar crianças brincando nas carvoarias, principalmente, devido a localização dos fornos, que se situam próximos às residências (Figura 19) e muitas dessas acompanham os pais durante o expediente de trabalho. 


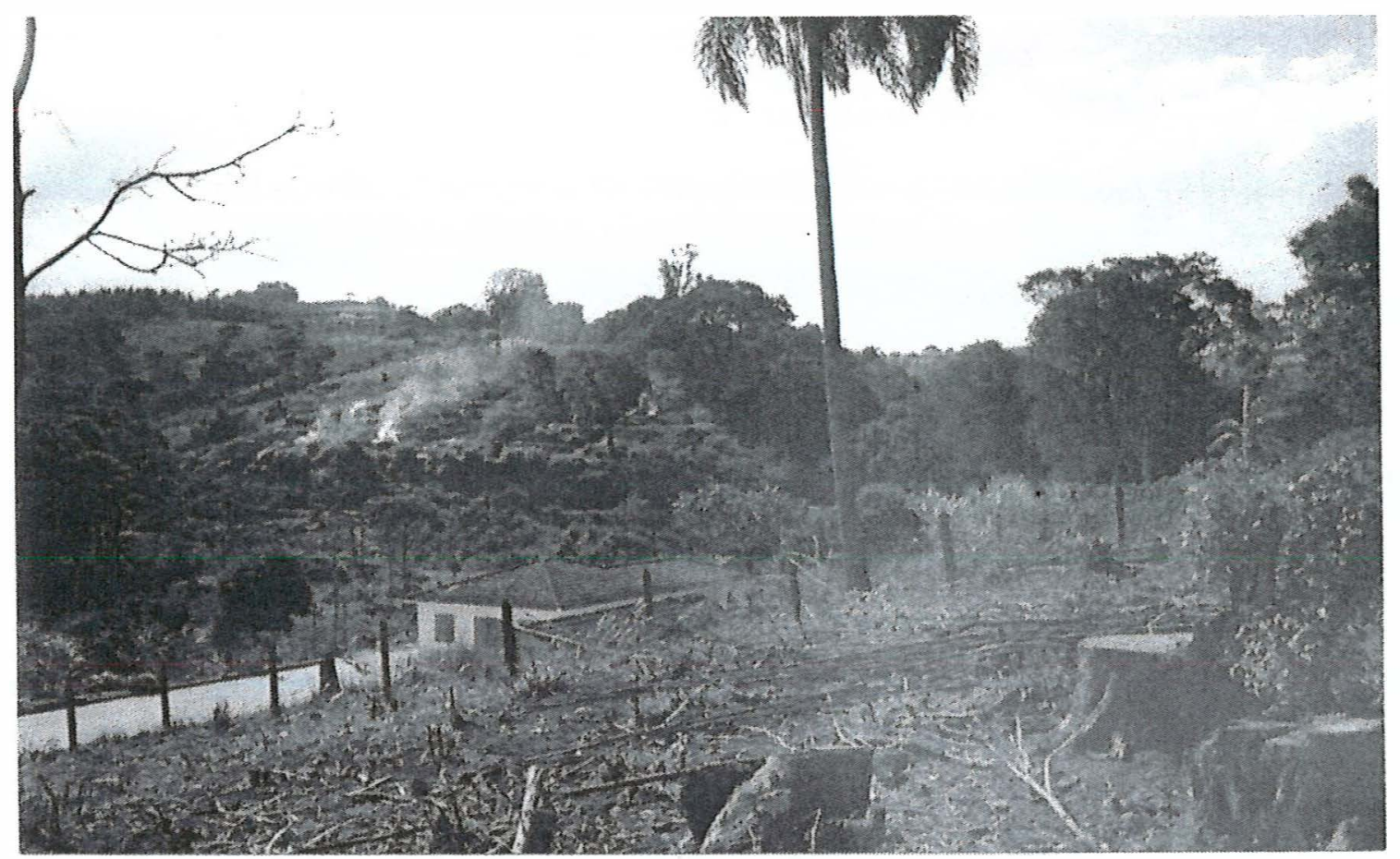

Figura 19 - Exemplo de fornos localizados próximos às residências

O grau de escolaridade dos trabalhadores ligados à atividade de carvão vegetal (Figura 20), raramente ultrapassa o primário, ou seja, poucos dos trabalhadores permanecem na escola por mais de quatro anos e apenas $14 \%$ deles concluíram o ensino fundamental ( $8^{\mathrm{a}}$ série). 


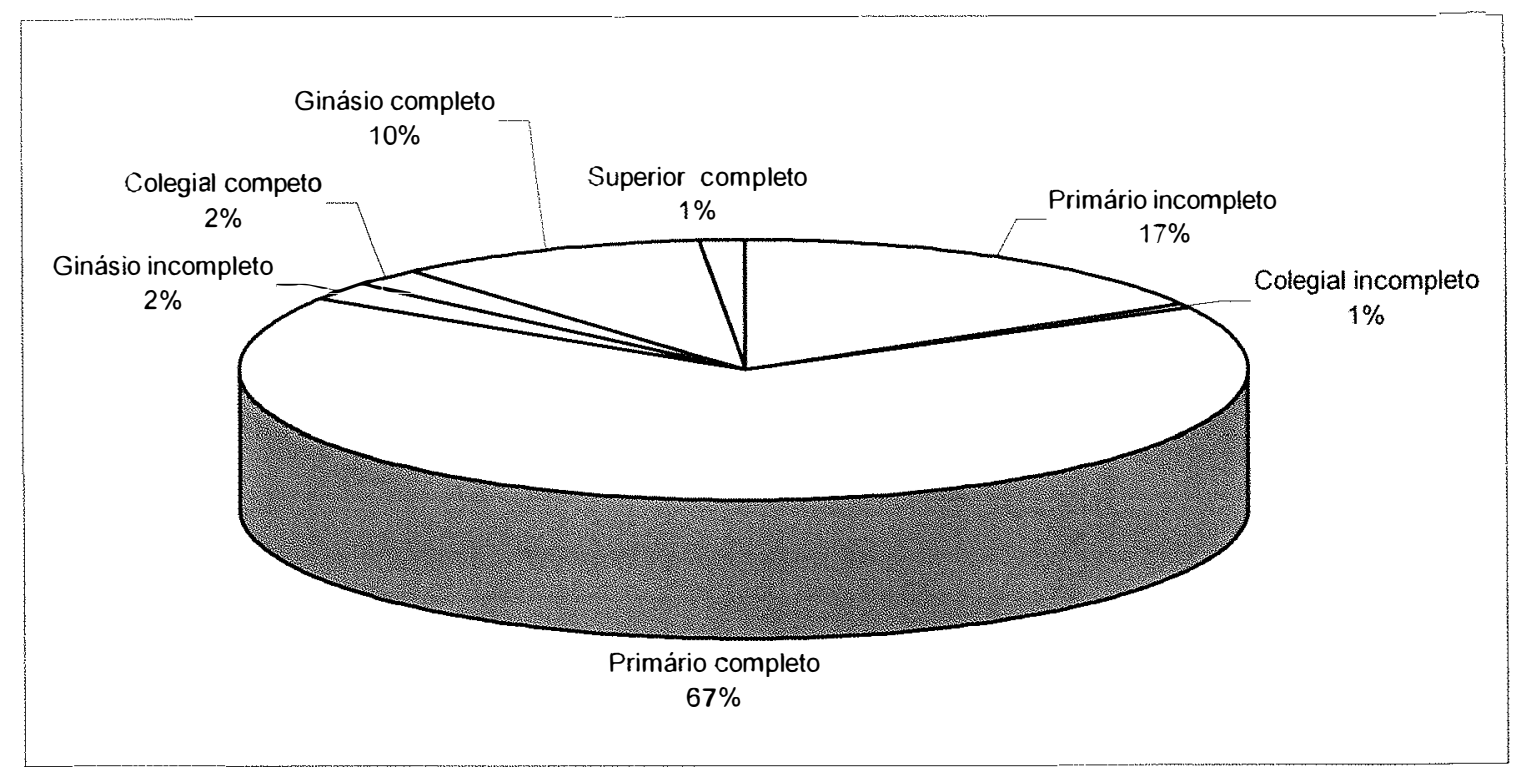

Figura 20 - Escolaridade dos trabalhadores ligados à atividade de carvão vegetal de Pedra Bela/SP

Dos vinte e oito empreendedores de carvão vegetal entrevistados, cerca de $30 \%$ já participaram de cursos de capacitação profissional, tais como os cursos oferecidos pelo SEBRAE, sobre orçamento, planilha de custos, comercialização e produção de carvão vegetal. Tais empreendedores alegam que o principal motivo de participarem desses cursos é o de conhecer e aprimorar suas técnicas de produção de carvão vegetal e agregação de novos valores para diferenciarem esse produto no mercado.

A remuneração média dos trabalhadores da atividade carvoeira é de $\mathrm{R} \$ 365,00$, variados de acordo com a categoria de mão-de-obra. Para os produtores a média é $R \$ 348,00$, os intermediários apresentam uma remuneração média é $R \$ 305,00$ e a maior média de $R \$ 464,00$ é atribuída aos produtores-distribuidores que, geralmente, encontram-se mais organizados e agregam maior valor ao produto.

O estudo permitiu a identificação de três categorias de mão-de-obra: 
- Familiar: pequenas empresas mantidas apenas por mão-de-obra da própria família, que geralmente não tem registro em carteira e cuja atividade é realizada dentro da propriedade;

- Contratada: funcionário com registro em carteira. Geralmente se encontram nas empresas de médio e grande porte;

- Temporária: são funcionários que não têm emprego fixo e circulam pelas empresas, sendo contatados conforme a necessidade de mão-deobra e demanda do mercado.

Existem nos empreendimentos duas formas de remuneração:

- fixa: com salários mensais fixos, geralmente pagos a funcionários contratados;

- por produção: a remuneração é definida pelo rendimento de cada funcionário, ou seja, pela quantidade de carvão vegetal produzida e/ou embalada e para cada saco de $20 \mathrm{~kg}$ de carvão são pagos cerca de $\mathrm{R} \$ 0,55$. 
Tabela 11. Estimativa de receita dos empreendimentos e preços do carvão vegetal

\begin{tabular}{|c|c|c|c|c|}
\hline $\begin{array}{c}\text { N. do } \\
\text { empreendimento }\end{array}$ & $\begin{array}{c}\text { Atividade } \\
\text { desenvolvida }\end{array}$ & $\begin{array}{c}\text { Preço do carvão } \\
\text { (R\$/kg) }\end{array}$ & $\begin{array}{l}\text { Produção } \\
\text { estimada } \\
\text { (kg/mês) }\end{array}$ & $\begin{array}{l}\text { Receita máxima } \\
\text { (R\$/mês) }\end{array}$ \\
\hline 1 & produtor & 0,25 & 24.675 & $6.168,75$ \\
\hline 2 & produtor & 0,25 & 18.750 & $4.687,50$ \\
\hline 3 & produtor & 0,23 & 31.250 & $7.187,50$ \\
\hline 4 & produtor & 0,22 & 66.000 & $14.520,00$ \\
\hline 5 & produtor & 0,23 & 30.000 & $6.900,00$ \\
\hline 6 & produtor & 0,25 & 5.130 & $1.282,50$ \\
\hline 7 & produtor & 0,25 & 12.600 & $3.150,00$ \\
\hline 8 & produtor & 0,2 & 40.625 & $8.125,00$ \\
\hline 9 & produtor-distribuidor & 0,4 & 105.089 & $42.035,63$ \\
\hline 10 & produtor & 0,22 & 34.931 & $7.859,53$ \\
\hline 11 & produtor & 0,22 & 13.500 & $3.037,50$ \\
\hline 12 & produtor & 0,25 & 7.500 & $1.875,00$ \\
\hline 13 & produtor-distribuidor & 0,4 & 90.750 & $36.300,00$ \\
\hline 14 & produtor & 0,23 & 90.514 & $20.818,29$ \\
\hline 15 & produtor & 0,25 & 74.250 & $18.562,50$ \\
\hline 16 & produtor-distribuidor & 0,4 & 27.600 & $11.040,00$ \\
\hline 17 & produtor & 0,27 & 75.000 & $20.250,00$ \\
\hline 18 & produtor & 0,33 & 55.200 & $18.216,00$ \\
\hline 19 & produtor & 0,2 & 16.500 & $3.300,00$ \\
\hline 20 & produtor & 0,25 & 20.250 & $5.062,50$ \\
\hline 21 & produtor-distribuidor & 0,45 & 25.714 & $11.571,43$ \\
\hline 22 & produtor & 0,24 & 20.286 & $4.970,07$ \\
\hline 23 & produtor & 0,25 & 26.250 & $6.562,50$ \\
\hline 24 & produtor-distribuidor & 0,65 & 76.286 & $49.585,71$ \\
\hline 25 & produtor & 0,22 & 18.750 & $4.125,00$ \\
\hline 26 & produtor & 0,24 & 19.238 & $4.617,00$ \\
\hline 27 & intermediário & 0,4 & 24.480 & $9.792,00$ \\
\hline 28 & intermediário & 0,35 & 6.600 & $2.310,00$ \\
\hline Média & - & 0,28 & $37.775,6$ & $11.925,43$ \\
\hline Total & - & 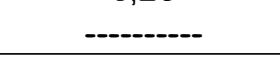 & $1.026 .638,1$ & $321.809,90$ \\
\hline
\end{tabular}

Nota-se que há uma importante diferença de preço de carvão entre os diversos tipos de atividades exercidas (Tabela 11).

O preço médio de carvão comercializado pelo produtor é de $\mathrm{R} \$ 0,28 / \mathrm{kg}$. Geralmente, o carvão é vendido para os chamados "intermediários" que compram o carvão vegetal diretamente dos produtores e repassam aos grandes distribuidores a um preço médio de $\mathrm{R} \$ 0,38 / \mathrm{kg}$. Os distribuidores por sua vez, 
revendem o carvão vegetal empacotado aos varejistas a um preço médio de $\mathrm{R} \$ 0,48 / \mathrm{kg}$ (Figura 21).

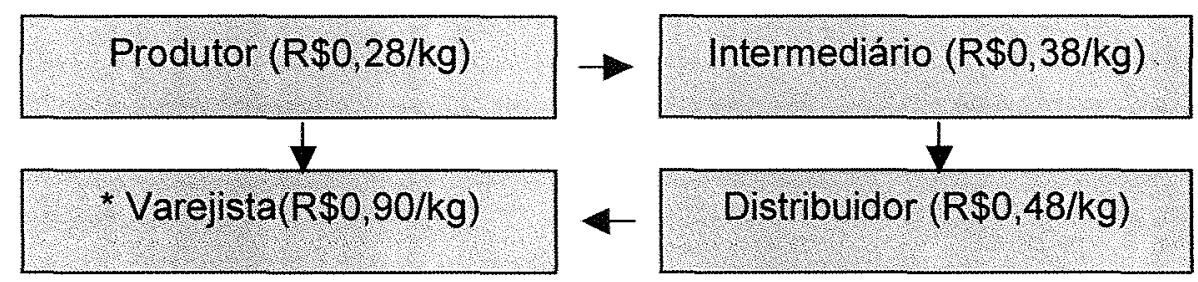

* Dados levantados junto à supermercados de Piracicaba, em junho de 2002

Figura 21 - Trajeto do carvão vegetal produzido no Município de Pedra Bela/SP

Segundo depoimento de antigos moradores do Município e produtores de carvão, no inicio eram poucos os produtores de carvão vegetal no local, todavia, com o declínio da produção da batata e com a falta de opção de trabalho, muitas pequenas propriedades passaram a produzir o carvão como uma forma de geração imediata de renda, o que contribuiu para sucatear ainda mais o preço do carvão e desarticular a cadeia produtiva da região, pois segundo os mesmos, o carvão é vendido pelo preço que o comprador oferece o qual, geralmente, não é suficiente para cobrir os gastos para sua produção.

A maioria dos produtores reclama do baixo preço carvão vegetal e da sua estagnação, que há cinco anos tem o mesmo valor. Muitos produtores de carvão vegetal estão trabalhando com uma margem mínima de lucro, uma vez que a matéria-prima é, para a maioria deles, adquiridos de terceiros e o carvão vegetal chega a apresentar, segundo alguns produtores um custo que varia de $\mathrm{R} \$ 0,19 / \mathrm{kg}$ a $\mathrm{R} \$ 0,21 / \mathrm{kg}$.

Segundo estudo realizado pelo Pró-Carvão (2001), o custo de produção do carvão vegetal depende das condições de sua produção, custo de mão-deobra, custo da lenha na carvoaria, custo do forno, entre outros. Segundo Valente ${ }^{3}$ citado por Pró-carvão (2001), pode-se estimar esse custo, utilizando- 
se de uma fórmula que necessita apenas dos valores da diária do funcionário, sendo:

$\mathrm{R} \$ / \mathrm{mdc}=1,05(2 \mathrm{M}+0,3 \mathrm{H})$

Onde:

$M=$ custo da lenha (st) colocada próxima ao forno;

$\mathrm{H}=$ valor da diária;

$M d c=m^{3}$ de carvão vegetal à granel.

Considerando-se, por exemplo, $\mathrm{R} \$ 15,94$ o valor do metro estéreo de lenha na carvoaria e $\mathrm{R} \$ 35,00$ o valor de uma diária de trabalho, respectivamente, tem-se um custo de $\mathrm{R} \$ 44,50 / \mathrm{mdc}$. Estimando-se uma densidade média de $240 \mathrm{~kg}$ de carvão/mdc, tem-se o custo médio da produção de carvão vegetal de $R \$ 0,19 / \mathrm{kg}$.Tal valor correspondente ao encontrado para custo de produção no Município de Pedra Bela.

Muitos produtores de carvão vegetal não tem nenhum tipo de planejamento das atividades e não tem noções de elaboração de planilha de custos, sendo que, muitos deles, não contabilizam nos custos de produção a mão-de-obra, por se tratar da mão de obra familiar e nem incluem o preço da madeira, quando as têm em suas propriedades.

3 VALENTE, O. F. Carbonização de madeira de eucalipto. Informe Agropecuário, v.12, n. 141, p. 74-79, 1986. 
A atividade de produção de carvão vegetal é pouco lucrativa, todavia, a falta de opção por uma fonte de renda faz com que a atividade carvoeira seja a mais atrativa para as pequenas propriedades.

Conforme a Tabela 11, a maior concentração de receita estimada é destinada aos que produzem e distribuem carvão vegetal. Isso indica a importância do incentivo a agregação de valores ao carvão e na possibilidade dos produtores se tornarem também distribuidores, principalmente os pequenos produtores, que são os que mais reclamam da baixa valorização do produto.

As entrevistas realizadas junto às lideranças locais, sobre o que seria necessário para impulsionar a atividade de carvoejamento no Município indicam que é preciso:

"Agregar valor ao produto final, com a formação de cooperativa de produtores e passar a entregar seu produto diretamente para supermercados e outros pontos de venda direta ao consumidor com embalagens apropriadas evitando-se assim o atravessador" (A . P. L. Prefeito Municipal)

"- Melhoria na tecnologia de produção;

- Melhoria na comercialização e agregação de valor ao produto;

- Organização dos pequenos produtores" (M. C. A. - CATI)

“- Ganho de eficiência na produção existente (fornos);

- Estabelecer padrões de qualidade para o produto (carvão);

- Estabelecer padrões de classificação para o produto;

- Criação de grupo formal (por exemplo, de uma associação etc) de produtores;

- Agregar valor ao produto através de diversas formas para atender mercados diferenciados. (J. R. C. P. Programa SAI) 


\subsection{Aspectos Ambientais}

Os resultados da análise dos aspectos ambientais são apresentados na Tabela 12 e ilustrados nas Figuras de 22 a 24.

Os maiores impactos oriundos da atividade de produção de carvão vegetal são a poeira e a fumaça, dado principalmente a proximidade entre os fornos e as residências. Em algumas propriedades há reclamações de vizinhos e de membros da própria família quanto a forte poluição do ar produzido com a carbonização da madeira. 


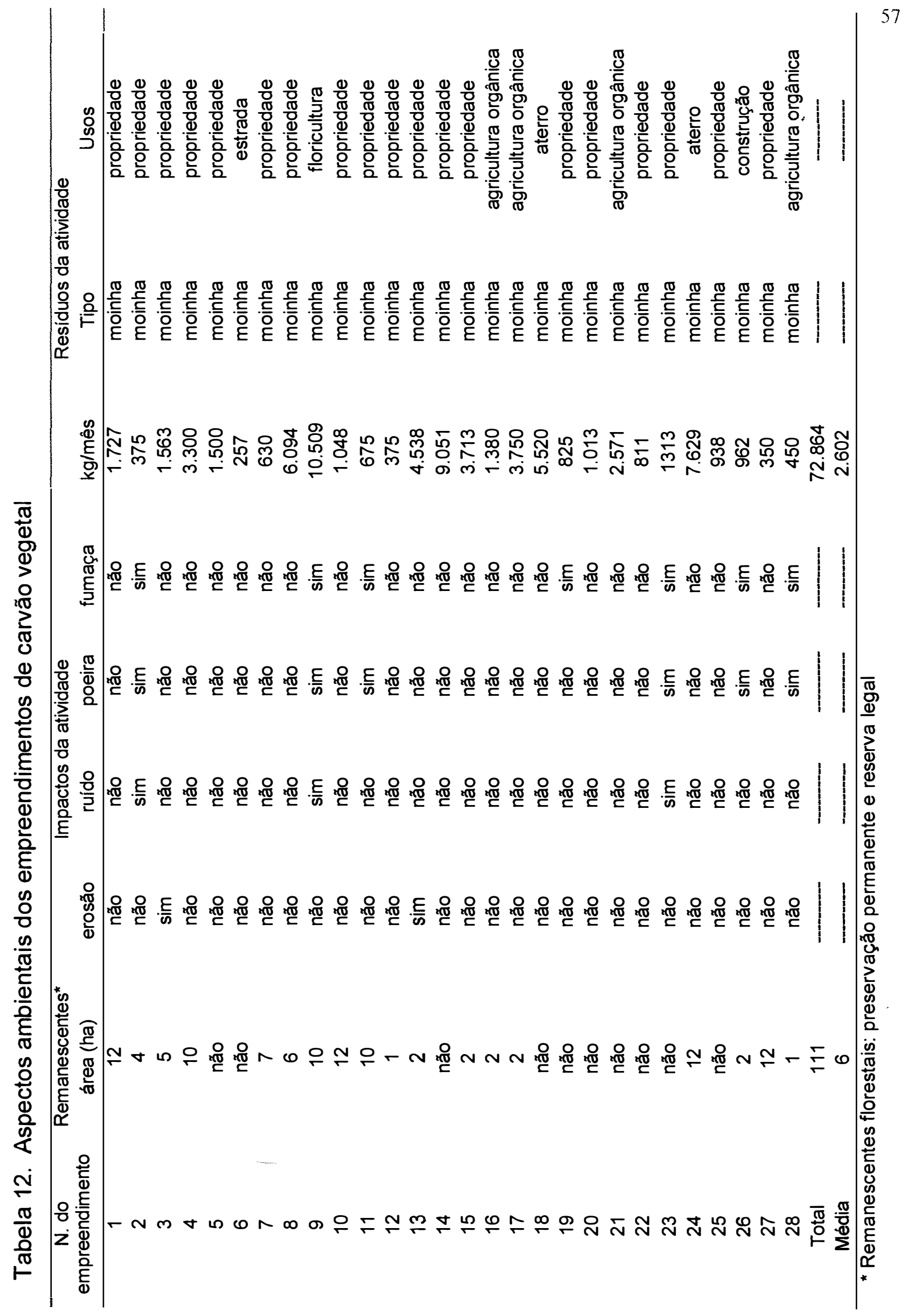




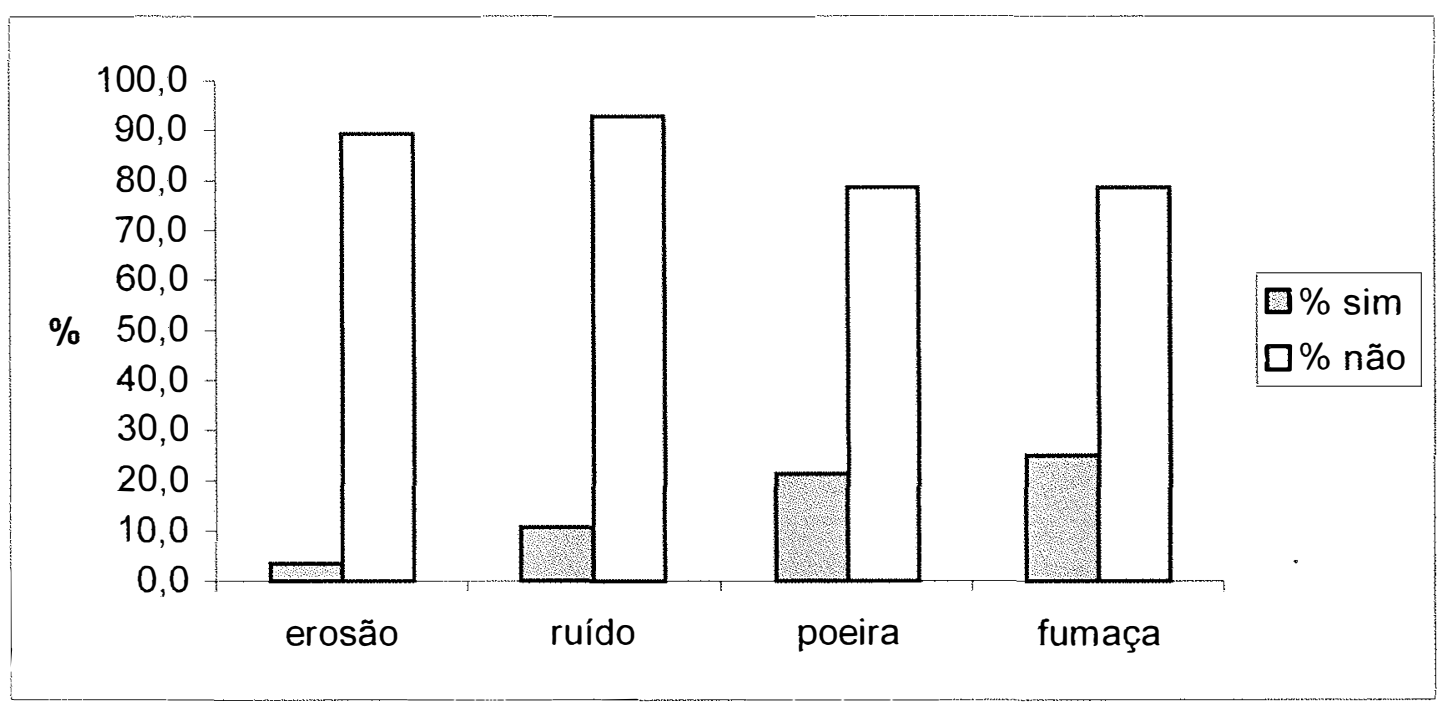

Figura 22 - Incidência dos principais impactos ambientais advindos do carvoejamento, segundo os empreendedores

Apenas cerca de $7 \%$ dos terrenos utilizados para a produção de carvão vegetal encontram-se com erosão que segundo os proprietários, são oriundas da produção a outras culturas anteriormente existentes nesses locais, tais como a cultura de batata e a pastagem. 


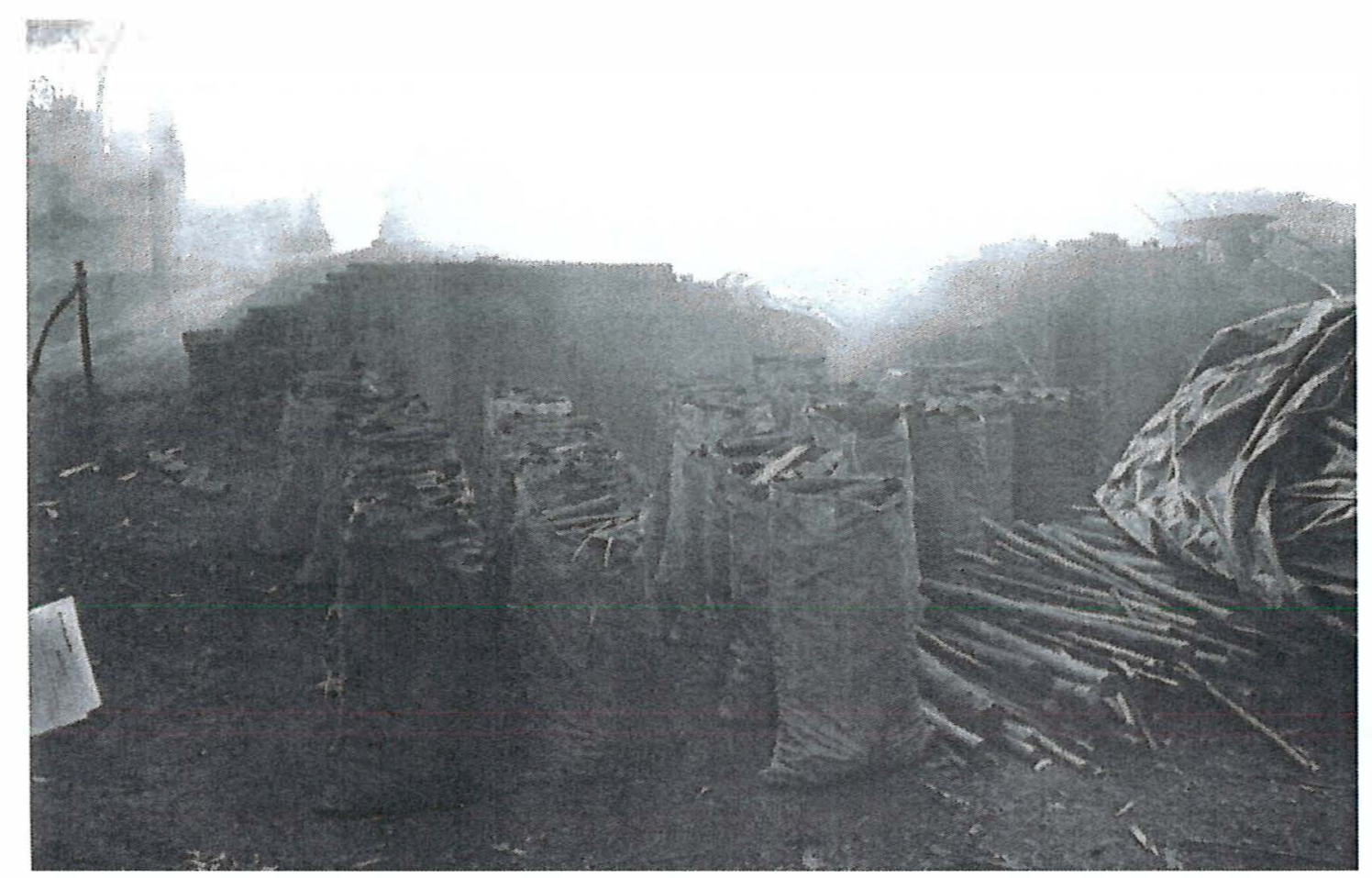

Figura 23 - Impactos da poluição do ar numa carvoaria típica do Município de Pedra Bela - SP

Há grande expectativa em relação a difusão de tecnologias acessiveis para que os produtores possam retirar o extrato pirolenhoso, principalmente para minimizar a grande concentração de fumaça na região. Tal tecnologia poderá melhorar a qualidade do ar para as famílias que moram nestes locais e agregar maior valor a atividade através da retirada e beneficiamento do licor pirolenhoso.

Cerca de $64 \%$ das propriedades apresentam áreas com vegetação nativa e, quando existentes, o tamanho médio dessas áreas é de 6ha. Tratamse de pequenos fragmentos florestais, que não foram desmatamentos, principalmente devido a sua localização. Situam-se em sua maioria em áreas de grande declividade e nas margens de córregos (áreas de preservação permanente). 


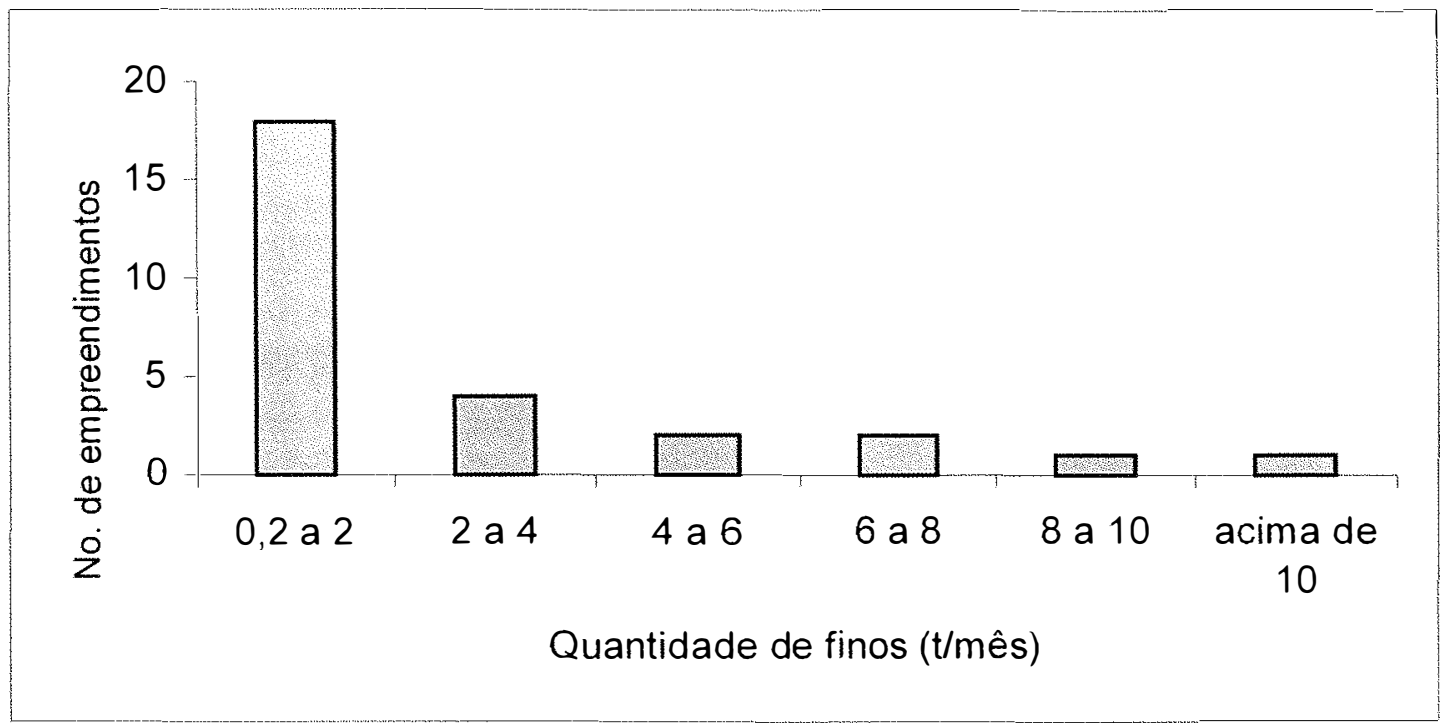

Figura 24 - Finos de carvão vegetal das propriedades de Pedra Bela

O nível médio de perda pela produção de finos ou moinha de carvão representa uma média de $6 \%$ da produção. Estima-se que cerca de 72 toneladas de finos de carvão vegetal sejam descartados mensalmente nas propriedades no Município e, na maioria dos casos, esse resíduo é depositado nas proximidades dos locais de carbonização.

Em alguns casos, os finos são aplicados para diminuição de erosão nas estradas e uma pequena parte é destinada à adubação na produção de hortaliças e viveiros de mudas. Segundo os produtores de carvão vegetal, o custo do transporte não compensa a venda do pó devido, principalmente, a baixa valorização desse no mercado (de $R \$ 0,02 / \mathrm{kg}$ a $R \$ 0,08 / \mathrm{kg}$ na região de Pedra Bela).

Segundo os produtores, os finos são deixados na propriedade por falta de melhor opção, mas que esse material é deixado à disposição para ser doado. Na região já aconteceram acidentes com produtores que se queimaram com a moinha próxima à carvoaria, que algumas vezes pode permanecer em combustão. 


\subsection{Parâmetros de Qualidade do Carvão Vegetal}

A qualidade do carvão vegetal é um dos principais aspectos para sua aceitação no mercado. A qualidade pode ser medida através de alguns parâmetros, tais como capacidade de ignição, sua resistência, durabilidade, nível de umidade, presença de tiço, limpeza, entre outros. Busca-se uma produção de carvão que agregue, na medida do possível, todos esses atributos, e que mantenha, bom padrão de qualidade.

Os resultados dos testes de qualidade realizados para o carvão vegetal produzidos no município de Pedra Bela são apresentados nas Tabelas 13 a 19 e ilustrados na Figuras 25 e 26. O produto está em sua maioria, em consonância com os parâmetros de qualidade existentes, o que poderá servir para agregação de valor do produto (carvão vegetal) junto ao mercado consumidor. 
Tabela 13. Indicação oferecida pelos empreendedores quanto aos fatores que influenciam na qualidade do carvão vegetal no Município de Pedra Bela - SP

\begin{tabular}{|c|c|c|c|c|c|c|c|c|c|c|c|}
\hline \multirow{2}{*}{$\begin{array}{c}\text { No. do } \\
\text { empreendimento }\end{array}$} & \multicolumn{11}{|c|}{ Fatores que influenciam na qualidade do carvão vegetal } \\
\hline & 1 & 2 & 3 & 4 & 5 & 6 & 7 & 8 & 9 & 10 & 11 \\
\hline 1 & $x$ & $x$ & & & & & & & & & \\
\hline 2 & $x$ & & & & & & & $x$ & & & \\
\hline 3 & $x$ & & & & & & & $x$ & & & \\
\hline 4 & $x$ & & & & & & $x$ & & & & $x$ \\
\hline 5 & & $x$ & & & & & & $x$ & & & \\
\hline 6 & $x$ & & & & & & & & & & \\
\hline 7 & $x$ & $x$ & & & & & & & & & \\
\hline 8 & $x$ & & & & & $x$ & & & & & \\
\hline 9 & $x$ & $x$ & $x$ & $x$ & $x$ & $x$ & $x$ & & & & \\
\hline 10 & & $x$ & & & & & & & $x$ & $x$ & \\
\hline 11 & & $x$ & & & $x$ & & & & & $x$ & \\
\hline 12 & $x$ & $x$ & & $x$ & & $x$ & & $x$ & & & \\
\hline 13 & & $x$ & $x$ & & & & & & & & \\
\hline 14 & & $x$ & & & & $x$ & & & & & \\
\hline 15 & & & $x$ & & $x$ & & & & $x$ & & \\
\hline 16 & & & $x$ & & $x$ & & & & & & \\
\hline 17 & $x$ & $x$ & & & & & & & & & \\
\hline 18 & $x$ & $x$ & & & & & & & & & \\
\hline 19 & $x$ & $x$ & & & & & & & & & \\
\hline 20 & & $x$ & & & $x$ & & & & & & \\
\hline 21 & & & $x$ & $x$ & & & $x$ & & & & \\
\hline 22 & $x$ & & & $x$ & $x$ & & & & & & \\
\hline 23 & & $x$ & & & & & & & $x$ & & \\
\hline 24 & & $x$ & & $x$ & & & & & $x$ & & \\
\hline 25 & & $x$ & & & & $x$ & & & & & \\
\hline 26 & $x$ & $x$ & & & & & & $x$ & & & \\
\hline 27 & & $x$ & & & & & & & & & \\
\hline 28 & $x$ & & & & & $x$ & $x$ & & & & $x$ \\
\hline
\end{tabular}

1- espécie; 2-densidade; 3-capacidade de ignição; 4-limpeza;

5- acendimento; 6-preço; 7-granulometria; 8-mão-de-obra;

9- durabilidade; 10-resistência 11- embalagem 


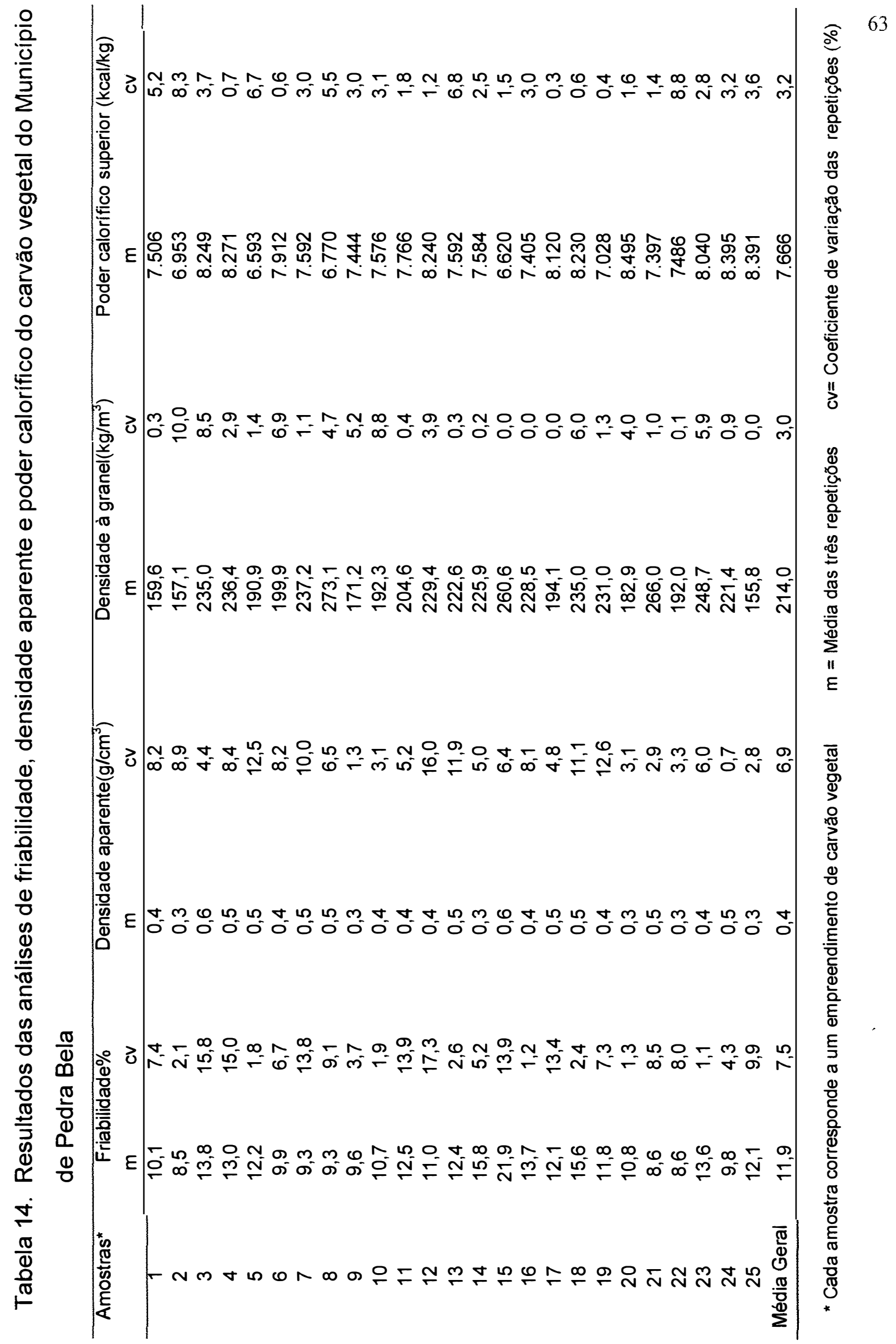




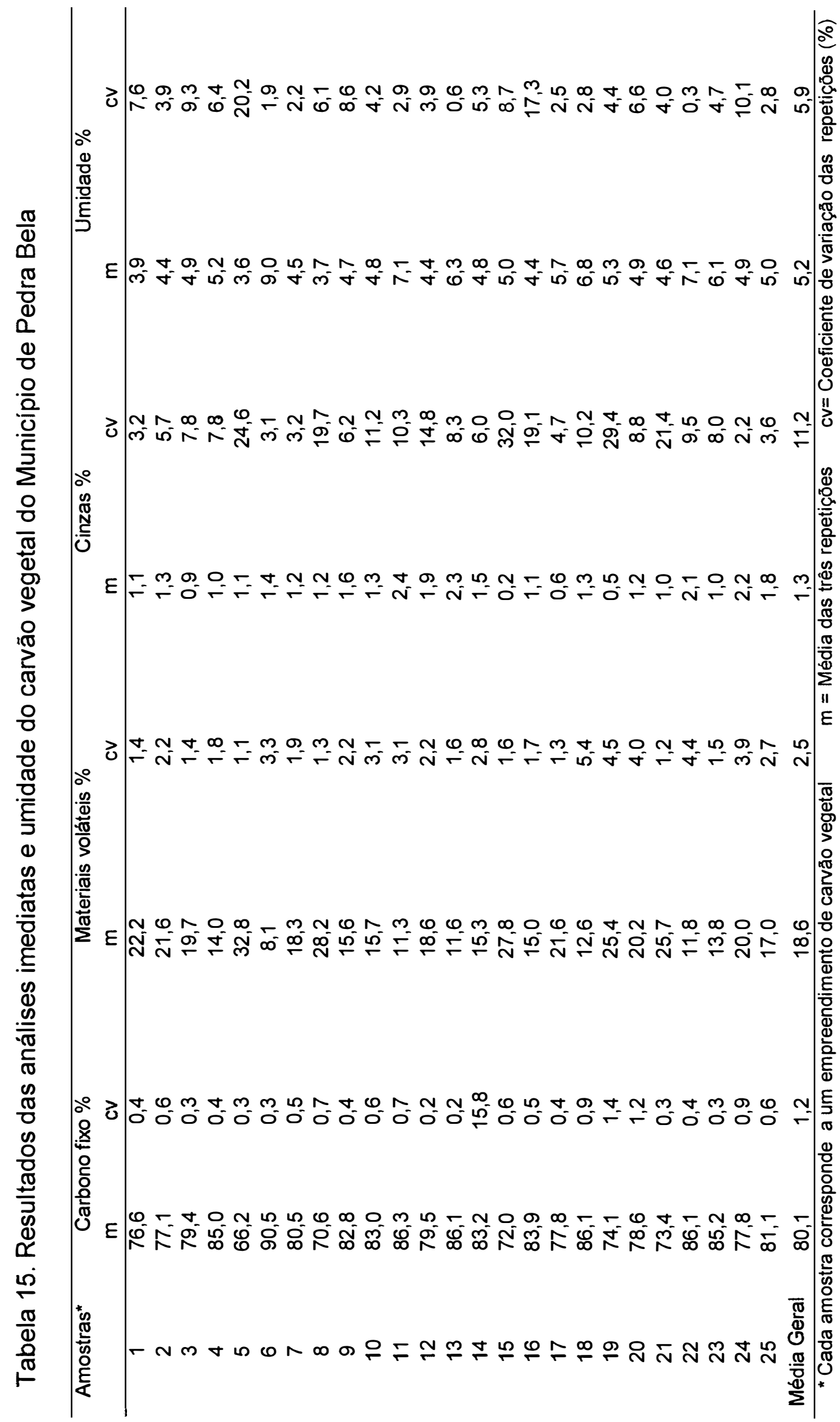




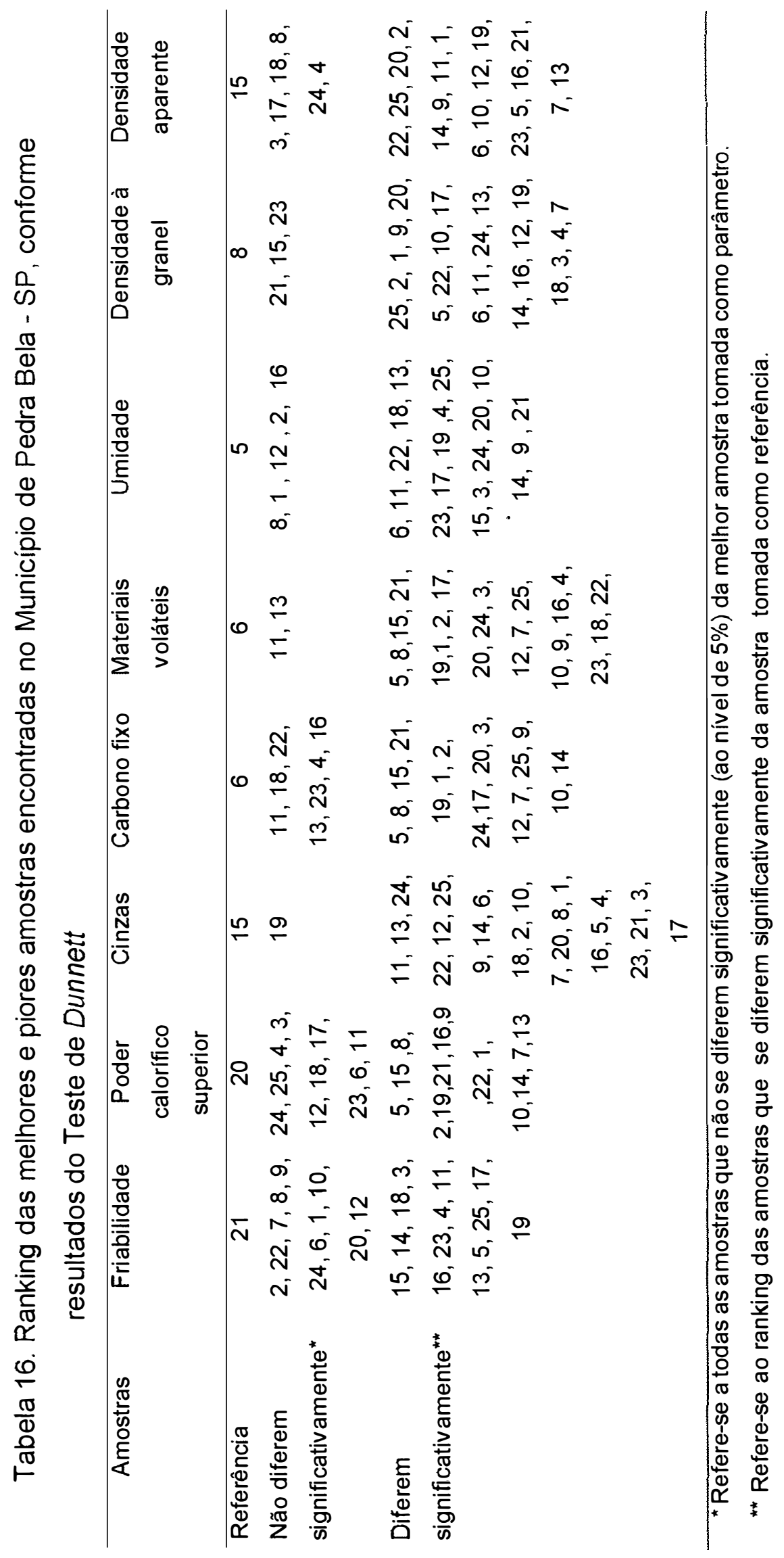




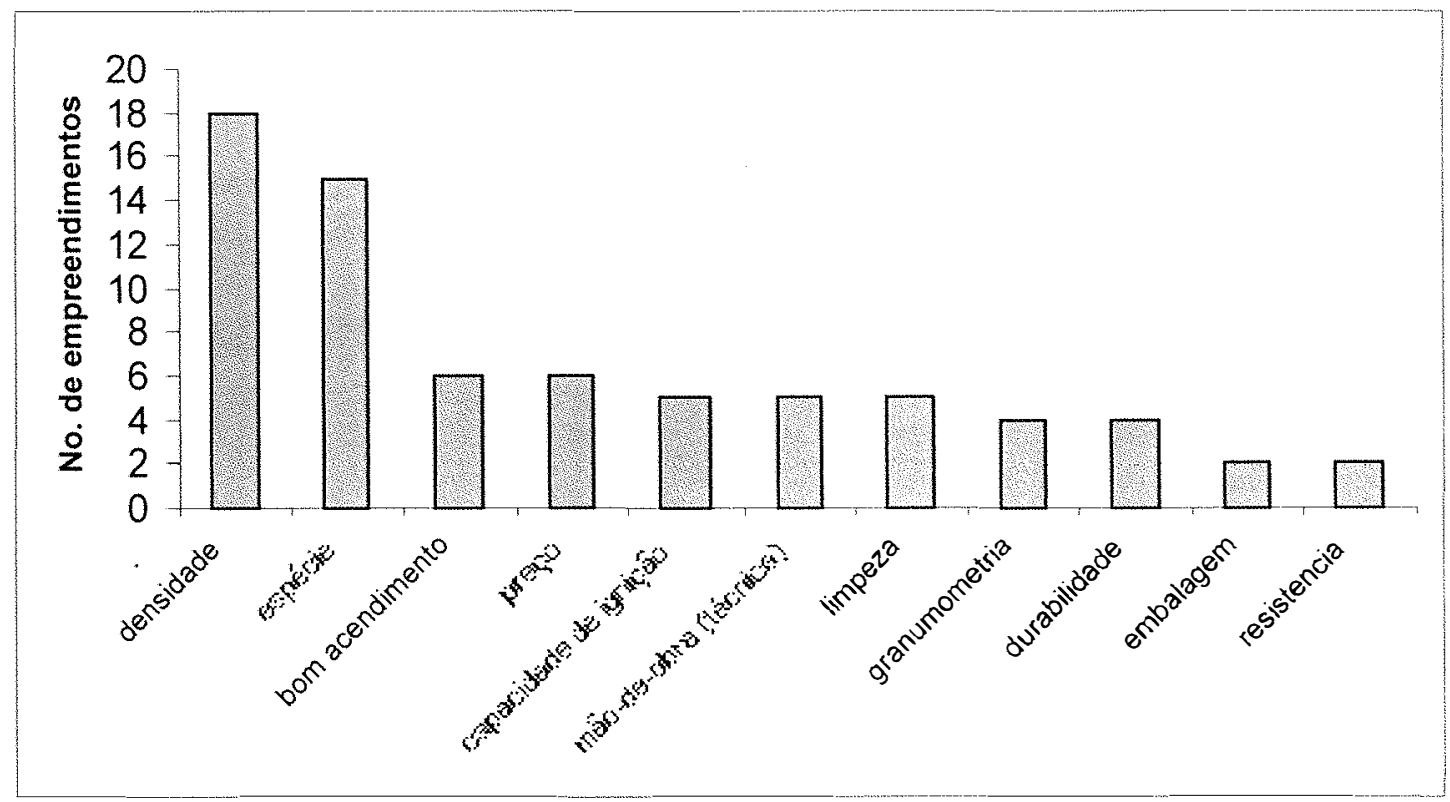

Figura 25 - Fatores considerados importantes para a qualidade do carvão vegetal

Segundo os produtores de carvão vegetal, o fator que mais influencia na qualidade do produto é a matéria-prima utilizada. Segundo os produtores, com a escassez da matéria-prima na região (Eucalyptus saligna), está sendo utilizada uma espécie de baixa densidade o que vem levando a produção de um carvão de queima rápida e de baixa qualidade.

Outros fatores considerados como mais importantes pelos empreendedores foram densidade, espécie utilizada, preço, bom acendimento e mão -de-obra qualificada. 


\subsubsection{Friabilidade}

Através do teste realizado, pode-se verificar que o carvão produzido no Município de Pedra Bela tem baixo poder de quebra, ou seja, $88 \%$ do carvão apresenta baixa friabilidade (Tabela 17 e Figura 26), um dos parâmetros que demonstra a boa qualidade do carvão produzido no Município.

Tabela 17. Classificação dos empreendimentos de Pedra Bela, quanto a friabilidade do carvão vegetal

\begin{tabular}{lcc}
\hline \multicolumn{1}{c}{ Classificação } & N. de empreendimentos & $\%$ \\
\hline muito pouco friável & 8 & 32 \\
pouco friável & 14 & 56 \\
medianamente friável & 3 & 12 \\
bastante friável & 0 & 0 \\
muito friável & 0 & 0 \\
\hline
\end{tabular}

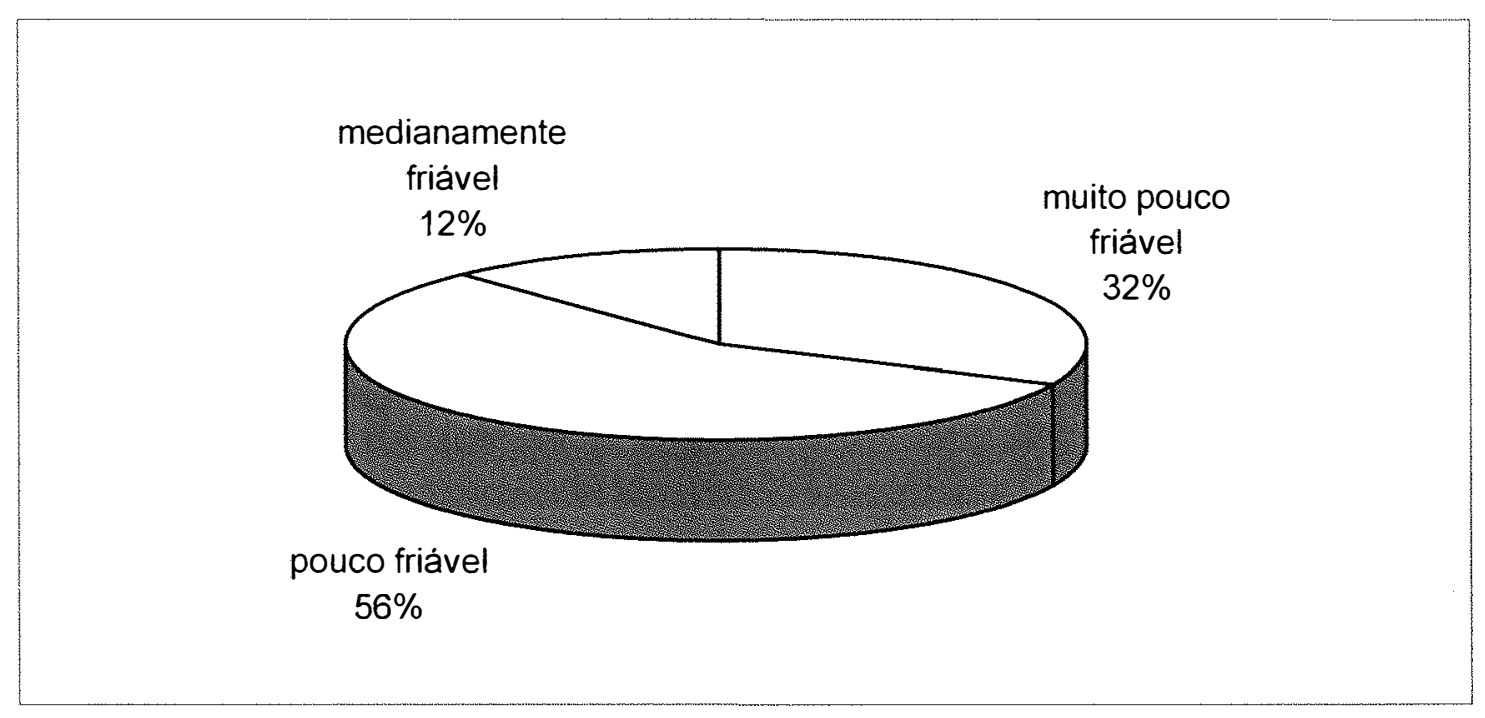

Figura 26 - Friabilidade do carvão vegetal produzido em Pedra Bela 
Através dos testes estatísticos realizados (Apêndice 3) nota-se que os menores valores de friabilidade são apresentados pelas amostras 2, 22, 7, 8, 9, $24,6,1,10,20$ e 12 que não apresentam diferença significativa quando comparados à amostra de menor friabilidade (21).

\subsubsection{Poder Calorífico}

Pode-se verificar que a amostra 20 é superior às demais. A amostra 15 e 5 são as que apresentaram as menores médias com relação ao poder calorífico.

Pode-se verificar através do teste de Dunnett que as melhores amostras, ou seja, aquelas que possuem maior poder calorífico são $24,25,4,3,12,18$, $17,23,6$, e 11, por não apresentarem diferença significativa ao nível de $5 \%$ de probabilidade, quando comparadas a melhor como referência (amostra 20).

\subsubsection{Análise Imediata}

De acordo com o teste de Dunnett, as melhores amostras tomadas como padrão para a análise de carbono fixo, materiais voláteis e cinzas foram as amostras 11 e 13 para o primeiro; $11,18,22,13,23,4$ e 16 para o segundo e 19 para a última. Estas amostras não apresentaram diferença significativa ao nível de 5\% quando comparadas as amostras de referência.

A quantidade superior de carbono fixo nas amostras é um indicador da qualidade do carvão vegetal. Segundo Juvillar (1980), um carvão quimicamente bom deve apresentar alta taxa de carbono fixo, baixa porcentagem de cinzas .

A maior parte do carvão vegetal produzido no Município de Pedra Bela $(92 \%)$ apresentam de 70 a $90 \%$ de carbono fixo. Provavelmente muito próximo de carvão ativado.

O carvão ativado é um produto diferenciado no mercado, o que lhe atribui um alto valor agregado, principalmente por ser utilizado pela indústria farmacêutica. Um estudo mais aprofundado de viabilidade e aceitação do 
carvão ativado no mercado poderia proporcionar e potencializar a diferenciação do produto, visando geração de renda para os produtores do Município.

\subsubsection{Umidade do Carvão Vegetal}

Tabela 18. Teor de umidade das amostras de carvão vegetal

\begin{tabular}{cc}
\hline$\%$ de Umidade & No. de amostras \\
\hline 3 a $5 \%$ & 14 \\
5 a $7 \%$ & 8 \\
acima de $7 \%$ & 3 \\
Total & 25 \\
\hline
\end{tabular}

O carvão vegetal produzido no Município de Pedra Bela apresenta teor médio de umidade de $5,2 \%$. Através do teste de Dunnett pode-se verificar que as melhores amostras, ou seja, aquelas que apresentaram menor umidade, foram as amostras 16, 2, 12, 1 e 8, por não demonstrarem diferenças significativas ao nível de $5 \%$, quando comparadas a melhor amostra (5) tomada como padrão.

\subsubsection{Densidade}

\subsubsection{Densidade à Granel e Aparente}

A densidade à granel média das amostras de carvão vegetal é de $214 \mathrm{~kg} / \mathrm{m}^{3}$. As amostras que apresentaram maiores valores para a densidades à granel foram: 21, 15 e 23 por não apresentarem diferenças significativas, quando comparada a amostra 8 , utilizada como referência.

Com relação à densidade aparente, as melhores amostras encontradas foram: $3,17,18,8,24$ e 4 que apresentam os maiores valores, e não apresentaram diferenças significativas ao nível de $5 \%$, quando comparadas com a amostra 15 tomada como referência. 


\subsubsection{Dados Sobre a Qualidade do Carvão Vegetal nos Empreendimentos}

$\mathrm{Na}$ tabela a seguir são apresentados os resultados obtidos da avaliação do carvão produzidos pelos empreendimentos em estudo.

As amostras que apresentaram maior destaque no conjunto dos parâmetros analisados foram agrupadas. As amostras que se sobressaíram com maior número parâmetros foram classificadas como as melhores amostras, conforme demonstrado na Tabela 19. 
Tabela 19. Resumo de dados para o conjunto para as melhores amostras analisadas

\begin{tabular}{|c|c|c|c|c|c|c|c|c|c|c|}
\hline \multirow[t]{2}{*}{ Ensaio } & \multirow[t]{2}{*}{ Média } & \multirow{2}{*}{$\begin{array}{c}\text { Coeficiente } \\
\text { de variação } \\
\text { das amostras } \\
(\%)\end{array}$} & \multicolumn{8}{|c|}{$\begin{array}{l}\text { Amostras que reúnem } \\
\text { melhores características, } \\
\text { segundo teste de Dunnett }\end{array}$} \\
\hline & & & 4 & 6 & 8 & 11 & 15 & 18 & 23 & 24 \\
\hline Friabilidade (\%) & 11,86 & 9,96 & & $\mathrm{x}$ & $x$ & & & & & $x$ \\
\hline $\begin{array}{l}\text { Poder calorífico superior } \\
(\mathrm{kcal} / \mathrm{kg})\end{array}$ & 7.666 & 3,82 & $x$ & $x$ & & $x$ & & $x$ & $x$ & $x$ \\
\hline Carbono fixo (\%) & 80,12 & 3,34 & $x$ & $x$ & & $x$ & & $x$ & $x$ & \\
\hline Materiais voláteis (\%) & 18,86 & 2,53 & & $x$ & & $x$ & & & & \\
\hline Cinzas (\%) & 1,31 & 11,19 & & & & & $x$ & & & \\
\hline Umidade (\%) & 5,25 & 6,34 & & & $x$ & & & & & \\
\hline Densidade à granel $\left(\mathrm{kg} / \mathrm{m}^{3}\right)$ & 214,04 & 4,16 & & & $x$ & & $x$ & & $x$ & \\
\hline Densidade aparente $\left(\mathrm{g} / \mathrm{cm}^{3}\right)$ & 0,432 & 9,31 & $x$ & & $x$ & & $x$ & $x$ & & $x$ \\
\hline
\end{tabular}

Os resultados apresentados acima demonstram que não houve grande variação entre as amostras dos empreendimentos envolvidos, o que indica um padrão e homogeneidade do carvão vegetal produzido no Município. Verificando-se o conjunto das amostras, observa-se que as de maior destaque foram: $4,6,8,11,15,18,23$ e 24, por apresentarem melhores características quanto aos parâmetros de qualidade analisados. 


\section{CONCLUSÕES}

O presente estudo detectou que a atividade de produção de carvão vegetal no Município de Pedra Bela apresenta uma série de problemas relacionados, principalmente, a obtenção de matéria-prima. A maioria dos empreendimentos possui pequeno e médio porte, com uma média de 23 fornos do tipo encosta. Foi possivel detectar ainda, que a maioria dos produtores atuam na informalidade, não apresentando registro junto ao IBAMA nem CNPJ.

Quanto aos aspectos sócio-ambientais, detectou-se que não há mão-deobra infantil nas carvoarias, mas que as crianças acompanham os pais na atividade, principalmente, devido a falta de opção para deixarem seus filhos e a proximidade dos fornos às residências. Os maiores impactos ambientais advindos da atividade estão relacionados com a disposição inadequada dos finos de carvão e a poluição do ar. Um aspecto bastante positivo é a manutenção de algum tipo de remanescente florestal por cerca de $64 \%$ dos estabelecimentos.

Este estudo permitiu também identificar que a demanda de madeira para a produção de carvão vegetal para o Município de Pedra Bela é superior à oferta da matéria-prima, indicando a necessidade de investimento na reposição florestal, caso contrário, haverá uma forte tendência da atividade de carvão vegetal decair, principalmente nas pequenas propriedades, que não têm condições de adquirir a matéria-prima de terceiros. É clara a necessidade de 
implementação de programas de fomento para estimulo ao reflorestamento no Município, com espécies propícias à atividade de carvoejamento.

Não se pode afirmar que a atividade carvoeira, embora tenha forte característica de informalidade, seja a responsável pelo empobrecimento do Municipio, uma vez que o histórico do local demonstra que a falta de alternativa de renda e a estagnação econômica já vinha ocorrendo na região. Verifica-se a necessidade de capacitação técnica e de programas que incentivem a adoção de novas tecnologias, propiciando que os produtores de carvão vegetal se tornem mais competitivos no mercado.

As análises laboratoriais realizadas indicam que no conjunto, o carvão vegetal produzido no Município encontra-se dentro dos padrões de qualidade existentes. Entretanto, foi possivel detectar que cerca de oito empreendimentos se sobressaem em relação aos demais, destacando-se em três ou quatro dos parâmetros analisados (friabilidade, poder calorífico, densidade aparente e à granel e análise imediata). 


\section{REFERÊNCIAS BIBLIOGRÁFICAS}

ASSOCIAÇÃO BRASILEIRA DE FLORESTAS RENOVÁVEIS Consumo de carvão vegetal: anuário estatístico, São Paulo, 2001. 10p.

ASSOCIAÇÃO BRASILEIRA DE NORMAS TÉCNICAS. Norma para ensaios de qualidade de carvão vegetal. São Paulo, 1986. 40p.

BRITO. J. O. Princípios de produção e utilização de carvão vegetal de madeira. Documentos Florestais, , v. 9, p.1-21, 1990a.

BRITO, J. O. Carvão vegetal no Brasil: gestões econômicas e ambientais. Revista Estudos Econômicos, v. 4, n. 09, p. 221 -227, 1990b.

BRITO. J. O . Reflexões sobre a qualidade do carvão vegetal para uso siderúrgico. Circular Técnica IPEF, n. 181, p. 1 - 6, 1993

CARBONIZAÇÃO da madeira e os produtos obtidos. INFOTEC PRÓ-CARVÃO v.1, n. 1, p. 1-2, 2000.

CARVÃO reduz colesterol do ovo, Revista Pesquisa FAPESP, n 61, 1p. 2001.

COORDENADORIA DE ASSISTÊNCIA TÉCNICA E INTEGRAL. Relatório anual da CATI para o município de Pedra Bela. São Paulo, 2001. 15p. 
COUTINHO, A R. Qualidade do carvão vegetal correlacionada com as características da madeira de Eucalyptus saligna e temperatura de carbonização. Piracicaba, 1984. 77p. Dissertação (Mestrado) - Escola Superior de Agricultura “Luiz de Queiroz", Universidade de São Paulo.

DUBÉ, F.; COUTO, L. ; GARCIA, R.; ARAÚJO, G. A .A .; LEITE, H. G. SILVA, M.L. Avaliação econômica de um sistema agroflorestal com Eucalyptus sp. no noroeste de Minas Gerais: o caso da Companhia Mineira de Metais. Revista Árvore, v. 24, n. 4, p. 347-443, 2000.

GOMES, P.A. ; OLIVEIRA, J. B. Teoria da carbonização da madeira. In: FUNDAÇÃO CENTRO TECNÓlOGICO DE MINAS GERAIS. Manual CETEC: uso da madeira para fins energéticos. Belo Horizonte, p.10-27. 1982.

INSTITUTO BRASILEIRO DE GEOGRAFIA E ESTATÍstICA. Censo demográfico 2000: malha municipal digital do Brasil. Rio de Janeiro, 1997. 260p.

INFOENER Sistema de Informações Energéticas da Universidade de São Paulo. Instituto de Eletrotécnica e Energia da USP. < http://infoener.iee.usp.br/energia/> (11 jun.2002)

JUVILLAR, J. B. Tecnologia da transformação da madeira em carvão. In Fundação Centro Tecnológico de Minas Gerais. Manual CETEC: Uso da madeira para fins energéticos.. Belo horizonte. p. 67-82. 1980. 
MADEIRA: a matéria-prima do carvão vegetal. INFOTEC PRÓ-CARVÃO v.2, n. 2, p. 1-2, 2000.

MATA, H.T.C. Avaliação da demanda residencial rural de lenha como fonte de energia e alternativas de abastecimento por meio de floresta social. Viçosa, 1994. 124p. Dissertação (Mestrado) - Universidade Federal de Viçosa.

MOORER, W. E.; BELINGER, E. A method of charcoal analysis. Forest Products Journal, n.2, p.17-19, 1961.

MOREIRA, C.S. Contribuição da eficiência de pequenos fornos na produção de carvão vegetal destinado a alto forno. Universidade de São Paulo, Piracicaba, São Paulo. 1964. 110p. Tese (Doutorado) - Escola Superior de Agricultura "Luiz de Queiroz", Universidade de São Paulo.

NETTO, F. F. Estágio atual das pesquisas sobre o carvão vegetal. In: SEMINÁRIO NACIONAL SOBRE CARVÃO VEGETAL. 2, BELO HORIZONTE, 1980. Anais. Belo Horizonte: CETEC. 1980. 1-23p.

OLIVEIRA, J. B. ; GOMES, P.A.; ALMEIDA, M. A. Estudos preliminares de normalização de testes de controle de qualidade de carvão. In: Fundação Centro Tecnológico de Minas Gerais. Manual CETEC: Uso da Madeira para Fins Energéticos. Belo Horizonte Belo Horizonte, p. 09-38. 1980a.

OLIVEIRA, T. L.; ALMEIDA, M.R. Avaliação de carvão vegetal. In: Fundação Centro Tecnológico de Minas Gerais. Manual CETEC: Uso da Madeira para Fins Energéticos. Belo Horizonte, p43-54. 1980b. 
OLIVEIRA, A . D.; MACEDO, R. L. G. Sistemas agroflorestais: considerações técnicas e econômicas. Lavras: UFLA, 1996. 255p.

PASSOS, C. A. M. Sistemas agroflorestais com eucalipto para uso em programas de fomento florestal, na região de Divinópolis, MG. Viçosa. 1996. 146p. Tese (Doutorado) - Universidade Federal de Viçosa.

PENEDO, W. R. Tecnologia energética a partir da madeira. In: Seminário Nacional sobre Carvão Vegetal. BELO HORIZONTE, 1980. Anais: Belo Horizonte, CETEC. 1980. p. 1-19.

PRADO, M. (Org.) Os carvoeiros. Brasília: Ministério da Cultura. 1999. $192 p$.

PROGRAMA DE QUALIFICAÇÃO E CERTIFICAÇÃO DO CARVÃO VEGETAL NO ESTADO DE SÃO PAULO. Relatório descritivo SEBRAE. São Paulo. 2000. 68p.

QUIRINO, W. F. Características e índice de combustão de briquetes de carvão vegetal, Universidade de São Paulo, Piracicaba, São Paulo. 1991. 65p Dissertação (Mestrado) - Escola Superior de Agricultura "Luiz de Queiroz", Universidade de São Paulo.

SOCIEDADE DE INVESTIGAÇÃO FLORESTAL. Asfalto feito de fumaça de carvão. Viçosa, 2001. 4p. (Boletim Informativo)

SOUZA, M. P. Implicações sócio-ambientais do carvoejamento e reflorestamento no município de Coração de Jesus. Minas Gerais. 2000. 130p. Dissertação (Mestrado) - Universidade Federal de Viçosa. 
SUTTON, A . Trabalho escravo: um elo na cadeia de modernização do Brasil de hoje. São Paulo: Comissão da Pastoral da Terra, 1996. 15p.

TOLEDO, P. E. N.; SAGLIETTI, J. F. A.; BRITO, J. O. Eucalipto e pecuária extensiva: um estudo de caso em Torrinha (SP). Revista IEA, 2002./ No prelo/.

TRUGILHO, P. F. ; VITAL B.R.; REGAZZI,A. J.; GOMIDE,J.L. Aplicação da análise de correlação canônica na identificação de índices de qualidade da madeira de eucalipto para a produção de carvão vegetal. Revista Árvore, v.21, p. 259-267.1997.

VALE, A T.; NOGUEIRA, M. Carbonização de madeiras do cerrado e análise do carvão vegetal. Revista Árvore, v. 25, p.271-276, 2001.

VALE, A T.; NOGUEIRA, M.V.P.; SILVA, M.A. Rendimento do carvão vegetal de madeiras do cerrado em comparação ao Eucalyptus grandis. Revista Árvore, v. 20, p.93-99, 1996.

VALE, A T.; COSTA, A F. ; GONÇALEZ, J. C.; NOGUEIRA, M. Relações entre a densidade básica da madeira, o rendimento e a qualidade do carvão vegetal de espécies do cerrado. Revista Árvore, v.25, p. 89-95, 2001. 
APÊNDICES 


\section{APÊNDICE 1 \\ LEVANTAMENTO DE DADOS JUNTO ÀS EMPRESAS DE CARVÃO VEGETAL DO MUNICÍPIO DE PEDRA BELA - SP}

\section{DADOS BÁSICOS}

Nome do estabelecimento:

Nome do proprietário:

Rua:

Bairro:

CEP:

Cidade

Fone:

Fax:

Referencia para localização:

\section{DADOS DOS EMPREENDIMENTOS}

Atividades realizadas pela empresa:

$\square$ Produção Carvão Vegetal $\square$ Distribuição Carvão Vegetal

$\square$ Produção e Distribuição de Carvão Vegetal

No registro do IBAMA:

No CNPJ ou CPF

Localização: $\square$ Rural $\square$ Urbana

\section{MATÉRIA-PRIMA PARA A PRODUÇÃO DE CARVÃO VEGETAL}

\begin{tabular}{|c|c|c|c|c|c|c|c|c|}
\hline $\begin{array}{l}\text { Espécie } \\
\text { utilizada }\end{array}$ & $\begin{array}{l}\text { Área total } \\
\text { florestada } \\
\quad \text { (ha) }\end{array}$ & $\begin{array}{c}\text { Consumo } \\
\text { mensal de } \\
\text { madeira }\end{array}$ & St & $\mathrm{t}$ & $\begin{array}{c}\text { Custo } \\
\text { (R\$/unidad } \\
\text { e) }\end{array}$ & \multicolumn{2}{|c|}{$\begin{array}{c}\text { Matéria prima } \\
\text { Própria Terceiros }\end{array}$} & $\begin{array}{c}\text { Cidade de } \\
\text { Origem }\end{array}$ \\
\hline Eucalipto & & & $\square$ & $\square$ & & $\square$ & $\square$ & \\
\hline Pinus & & & $\square$ & $\square$ & & $\square$ & $\square$ & \\
\hline Nativa & & & $\square$ & $\square$ & & $\square$ & $\square$ & \\
\hline & & & $\square$ & $\square$ & & $\square$ & $\square$ & \\
\hline & & & $\square$ & $\square$ & & $\square$ & $\square$ & \\
\hline
\end{tabular}




\section{A origem da matéria-prima é comprovada? $\quad \square \quad$ Não $\square$ Sim}

Através de :

$\square$ Nota fiscal $\quad \square$ Guia de autorização para transporte $\quad \square$ recibo outros

\section{CARBONIZAÇÃO DO CARVÃO VEGETAL}

\begin{tabular}{c|ccc|} 
Tipo de forno & $\begin{array}{c}\text { Número de } \\
\text { fornos }\end{array}$ & $\begin{array}{c}\text { Capacidade do } \\
\text { forno (m3 de } \\
\text { lenha) }\end{array}$ & $\begin{array}{c}\text { Ciclo } \\
\text { (dias) }\end{array}$ \\
$\begin{array}{c}\text { Superfície } \\
\text { Rabo quente } \\
\text { Encosta } \\
\text { Outros }\end{array}$ & & \\
\hline
\end{tabular}

\section{COMERCIALIZAÇÃO DO CARVÃO VEGETAL}

\begin{tabular}{|r|r|}
\hline à granel & \\
\hline sacos de papel & \\
\hline outros & \\
\hline
\end{tabular}

\section{ASPECTOS SOCIAIS}

1. No. de pessoas que trabalham na atividade de carvão.

2. No. de pessoas por faixa etária:

- Até 10 anos - ( ) trabalhando ( ) Brincando ( ) outros

- 10 a 14 anos - ( ) trabalhando ( ) Brincando ( ) outros

- 14 a 18 anos - ( ) trabalhando ( ) Brincando ( ) outros

- 18 a 65 anos - ( ) trabalhando

- acima de 65 anos - ( ) trabalhando

3. No. de pessoas em idade escolar:

( ) Familia do Proprietário ( ) Familia do Funcionário

4. No. de pessoas por grau de escolaridade:

( ) Primário incompleto ( ) Primário completo ( ) Ginásio incompleto

( ) Ginásio completo ( ) Colegial incompleto ( ) Colegial completo

( ) Superior incompleto ( ) Superior completo 
5 - Remuneração Mensal $(R \$)$.

Registro em carteira de trabalho

Jornada de Trabalho.

\section{MEIO AMBIENTE}

1. Áreas Naturais

( ) Preservação Permanente - No. de ha

( ) Reserva Legal - No. de ha

( ) outros

2. OResíduos gerados:

a) Tipo de resíduos.

b) Local de descarte

c) Quantidade (mês).

3. Erosão ( ) sim ( ) Não

Formas de contenção

4. Poluição

a) ruído.

b) poeira.

c) fumaça

\section{INFRA-ESTRUTURA E EQUIPAMENTOS}

1) Equipamentos de segurança

( ) $\operatorname{sim}(\quad)$ não

Quais?

2) ( ) Escritório ( ) Energia elétrica

( ) Instalação Sanitária ( ) Água Potável ( ) Outros

\section{QUALIDADE DO PRODUTO}

1) O que você considera importante para a qualidade do carvão vegetal?

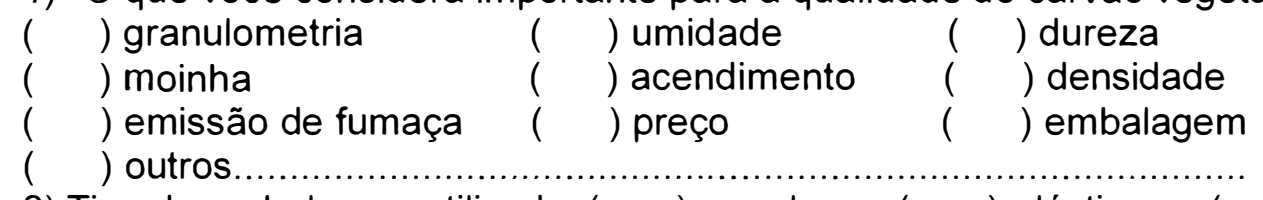

2) Tipo de embalagem utilizada ( ) papel ( ) plástico $($ ) ráfia

( ) reutliza embalagens.

\section{TECNOLOGIAS}

1) Tipos de equipamentos utlizados para produção e beneficiamento do carvão vegetal.

2) Utilização da moinha ( ) sim ( ) não

Finalidade.

3) Extração do licor pirolenhoso ( ) sim ( ) não 
Quantidade (litros).

$R \$$

Finalidade...

OBSERVAÇÕES GERAIS DOS EMPREENDIMENTOS 


\section{APÊNDICE 1.1}

\section{Entrevista semi-estruturada realizada em 06/06/02}

Nome:

Cargo

Tempo de atividade no Município:

1) Qual(is) a importância da atividade de carvoejamento para o Municipio? Por quê?

2) Quais são as expectativas com relação a continuidade dessa atividade em Pedra Bela (do ponto de vista de disponibilidade de matéria-prima, mão-deobra etc)?

3) O que você acredita que seja necessário para impulsionar o desenvolvimento/melhoria da atividade de carvoejamento no Município?

4) Já existe alguma proposta de programa/política pública de incentivo a atividade de carvoejamento para o Município? Qual(is)? Como implementálas? 


\section{APÊNDICE 2}

\section{ANÁLISE DE VARIÂNCIA PARA OS ENSAIOS LABORATORIAIS}

\section{Friabilidade}

Tabela 20. Análise da variância para a friabilidade das amostras de carvão vegetal

\begin{tabular}{lcccc}
$\begin{array}{l}\text { Fonte de } \\
\text { variação }\end{array}$ & G.L. & $\begin{array}{c}\text { Soma dos } \\
\text { Quadrados }\end{array}$ & $\begin{array}{c}\text { Quadrado } \\
\text { Médio }\end{array}$ & $\mathrm{F}$ \\
\hline Friabilidade & 24 & 624.97 & 26.04 & $18.65^{\star}$ \\
Residuo & 50 & 69.81 & 1.39 & \\
Total & 74 & 694.78 & & \\
\hline
\end{tabular}

* significativo ao nivel de $5 \%$ de probabilidade

Coeficiente de variação: $9,96 \%$

Média das amostras: 11.86

\section{Poder Calorífico Superior}

Tabela 21. Análise da variância para o poder calorifico das amostras de carvão vegetal

\begin{tabular}{lcccc}
\hline $\begin{array}{l}\text { Fonte de } \\
\text { variação }\end{array}$ & G.L. & $\begin{array}{c}\text { Soma dos } \\
\text { Quadrados }\end{array}$ & $\begin{array}{c}\text { Quadrado } \\
\text { Médio }\end{array}$ & $\mathrm{F}$ \\
\cline { 2 - 5 } $\begin{array}{l}\text { Poder } \\
\text { calorífico }\end{array}$ & 24 & $23.253 .836,8$ & $968.909,9$ & $11.27^{*}$ \\
$\begin{array}{l}\text { Residuo } \\
\text { Total }\end{array}$ & 50 & $4.297 .837,0$ & $85.956,7$ & \\
\hline
\end{tabular}

* significativo ao nivel de $5 \%$ de probabilidade

Coeficiente de variação: $3,82 \%$

Média das amostras: $7.666 \mathrm{kcal} / \mathrm{kg}$

\section{Análise Imediata}

\subsection{Materiais Voláteis}

Tabela 22. Análise da variância para os materiais voláteis das amostras de carvão vegetal

\begin{tabular}{|c|c|c|c|c|}
\hline $\begin{array}{l}\text { Fonte de } \\
\text { variação }\end{array}$ & G.L. & $\begin{array}{l}\text { Soma dos } \\
\text { Quadrados }\end{array}$ & $\begin{array}{c}\text { Quadrado } \\
\text { Médio }\end{array}$ & $F$ \\
\hline $\begin{array}{l}\text { Materiais } \\
\text { voláteis }\end{array}$ & 24 & 2.706 .101 & 112.75 & 494.11 \\
\hline $\begin{array}{l}\text { Residuo } \\
\text { Total }\end{array}$ & $\begin{array}{l}50 \\
74\end{array}$ & $\begin{array}{c}11.41 \\
2.717 .51\end{array}$ & 0.228 & \\
\hline
\end{tabular}

* significativo ao nivel de $5 \%$ de probabilidade Coeficiente de variação: $2,53 \%$

Média das amostras: 18,86 


\subsection{Cinzas}

Tabela 23. Análise da variância para o teor de cinzas das amostras de carvão vegetal

\begin{tabular}{lcccc}
\hline $\begin{array}{l}\text { Fonte de } \\
\text { variação }\end{array}$ & G.L. & $\begin{array}{c}\text { Soma dos } \\
\text { Quadrados }\end{array}$ & $\begin{array}{c}\text { Quadrado } \\
\text { Médio }\end{array}$ & $\mathrm{F}$ \\
\hline Cinzas & 24 & 22.63 & 0.94 & $43.53^{*}$ \\
Resíduo & 50 & 1.08 & 0.021 & \\
Total & 74 & 23.71 & & \\
\hline
\end{tabular}

* significativo ao nivel de $5 \%$ de probabilidade

Coeficiente de variação: $11.19 \%$

Média das amostras: 1,31

\subsection{Carbono Fixo}

Tabela 24. Análise da variância para o carbono fixo das amostras de carvão vegetal

\begin{tabular}{lcccc}
\hline $\begin{array}{c}\text { Fonte de } \\
\text { variação }\end{array}$ & G.L. & $\begin{array}{c}\text { Soma dos } \\
\text { Quadrados }\end{array}$ & $\begin{array}{c}\text { Quadrado } \\
\text { Médio }\end{array}$ & $\mathrm{F}$ \\
\hline Carbono fixo & 24 & $2.437,81$ & 101,57 & $14.14^{*}$ \\
Resíduo & 50 & 359,24 & 7,18 & \\
Total & 74 & $2.797,05$ & & \\
\hline
\end{tabular}

* significativo ao nível de $5 \%$ de probabilidade

Coeficiente de variação: $3,34 \%$

Média das amostras: 80,12

\subsection{Umidade}

Tabela 25. Análise da variância para a umidade das amostras de carvão vegetal

\begin{tabular}{lcccc}
\hline \multicolumn{1}{c}{$\begin{array}{c}\text { Fonte de } \\
\text { variação }\end{array}$} & G.L. & $\begin{array}{c}\text { Soma dos } \\
\text { Quadrados }\end{array}$ & $\begin{array}{c}\text { Quadrado } \\
\text { Médio }\end{array}$ & $\mathrm{F}$ \\
\hline Umidade & 24 & 109.33 & 4.55 & $41.04^{*}$ \\
Residuo & 50 & 5.55 & 0.11 & \\
Total & 74 & 114.88 & & \\
\hline
\end{tabular}

* significativo ao nivel de $5 \%$ de probabilidade

n.s. não significativo ao nivel de $5 \%$

Coeficiente de variação: $6,34 \%$

Média das amostras: 5,25 
4. Densidade

4.1 Densidade à granel

Tabela 26. Análise da variância para a densidade à granel das amostras de carvão vegetal

\begin{tabular}{lcccc}
\hline $\begin{array}{l}\text { Fonte de } \\
\text { variação }\end{array}$ & G.L. & $\begin{array}{c}\text { Soma dos } \\
\text { Quadrados }\end{array}$ & $\begin{array}{c}\text { Quadrado } \\
\text { Médio }\end{array}$ & F \\
\hline $\begin{array}{l}\text { Densidade à } \\
\text { granel }\end{array}$ & 24 & $54.100,20$ & $2.254,17$ & 28.32 \\
Residuo & 25 & $1.990,15$ & 79.60 & \\
Total & 49 & $56.090,36$ & & \\
\hline
\end{tabular}

* significativo ao nivel de $5 \%$ de probabilidade

Coeficiente de variação: $4,16 \%$

Média das amostras: $214,04 \mathrm{~kg} / \mathrm{m}^{3}$

\subsection{Densidade aparente}

Tabela 27. Análise da variância para a densidade aparente das amostras de carvão vegetal

\begin{tabular}{lcccc}
\hline \multicolumn{1}{c}{$\begin{array}{c}\text { Fonte de } \\
\text { variação }\end{array}$} & G.L. & $\begin{array}{c}\text { Soma dos } \\
\text { Quadrados }\end{array}$ & $\begin{array}{c}\text { Quadrado } \\
\text { Médio }\end{array}$ & F \\
\hline $\begin{array}{l}\text { Densidade } \\
\text { aparente }\end{array}$ & 24 & 0.45 & 0.018 & $11.60^{*}$ \\
Residuo & 50 & 0.08 & 0.0016 & \\
Total & 74 & 0.53 & & \\
\hline
\end{tabular}

* significativo ao nível de $5 \%$ de probabilidade

Coeficiente de variação: $9.31 \%$

Média das amostras: $0.432 \mathrm{~g} / \mathrm{cm} 3$ 


\section{APENNDICE 3}

\section{RESULTADOS DO TESTE DE DUNNETT PARA OS ENSAIOS LABORATORIAIS}

\section{Friabilidade}

Tabela 28. Resultados do teste de Dunnett para a friabilidade das amostras

\begin{tabular}{|c|c|c|}
\hline Amostra Referência & Amostra Contrastada & Contraste \\
\hline 21 & 15 & $13.31\left(^{*}\right)$ \\
\hline 21 & 14 & $7.22\left(^{*}\right)$ \\
\hline 21 & 18 & $7.03\left(^{*}\right)$ \\
\hline 21 & 3 & $5.19\left(^{*}\right)$ \\
\hline 21 & 16 & $5.16\left(^{*}\right)$ \\
\hline 21 & 23 & $5.06\left(^{*}\right)$ \\
\hline 21 & 4 & $4.43\left(^{*}\right)$ \\
\hline 21 & 11 & $3.88\left(^{*}\right)$ \\
\hline 21 & 13 & $3.87\left(^{\star}\right)$ \\
\hline 21 & 5 & $3.59\left(^{*}\right)$ \\
\hline 21 & 25 & $3.53\left(^{*}\right)$ \\
\hline 21 & 17 & $3.50\left(^{\star}\right)$ \\
\hline 21 & 19 & $3.18\left(^{*}\right)$ \\
\hline 21 & 12 & 2.38 (n.s.) \\
\hline 21 & 20 & 2.24 (n.s.) \\
\hline 21 & 10 & 2.13 (n.s.) \\
\hline 21 & 1 & 1.51 (n.s.) \\
\hline 21 & 6 & 1.27 (n.s.) \\
\hline 21 & 24 & 1.19 (n.s.) \\
\hline 21 & 9 & 1.04 (n.s.) \\
\hline 21 & 8 & 0.73 (n.s.) \\
\hline 21 & 7 & 0.69 (n.s.) \\
\hline 21 & 22 & 0.06 (n.s.) \\
\hline 21 & 2 & 0.11 (n.s.) \\
\hline
\end{tabular}

* significativo ao nível de $5 \%$ de significância

n.s. não significativo ao nivel de $5 \%$

\section{Poder Calorífico Superior}

Tabela 29. Resultados do teste de Dunnett para o poder calorífico das amostras

\begin{tabular}{ccc}
\hline Amostra Referência & Amostra Contrastada & Contraste \\
\hline 20 & 24 & $-99.8($ n.s.) \\
20 & 25 & $-103.9($ n.s.) \\
20 & 4 & -223.7 (n.s.) \\
20 & 3 & -245.5 (n.s.) \\
20 & 12 & $-254.5($ n.s.) \\
20 & 18 & $-265.0($ n.s.) \\
20 & 17 & -375.3 (n.s.) \\
20 & 23 & $-454.6($ n.s.) \\
\hline
\end{tabular}




\begin{tabular}{ccc}
20 & 6 & $-582.7($ n.s. $)$ \\
20 & 11 & $-729.4($ n.s. $)$ \\
20 & 13 & $-902.7\left(^{\star}\right)$ \\
20 & 7 & $-903.3\left(^{\star}\right)$ \\
20 & 14 & $-910.9\left(^{\star}\right)$ \\
20 & 10 & $-918.8\left(^{\star}\right)$ \\
20 & 1 & $-988.6\left(^{\star}\right)$ \\
20 & 22 & $-1008.6\left(^{\star}\right)$ \\
20 & 9 & $-1051.0\left(^{\star}\right)$ \\
20 & 16 & $-1090.3\left(^{\star}\right)$ \\
20 & 21 & $-1098.1\left(^{\star}\right)$ \\
20 & 19 & $-1467.3\left(^{\star}\right)$ \\
20 & 2 & $-1541.5\left(^{\star}\right)$ \\
20 & 8 & $-1724.8\left(^{\star}\right)$ \\
20 & 15 & $-1875.0\left(^{\star}\right)$ \\
20 & 5 & $-1901.4\left(^{\star}\right)$ \\
\hline
\end{tabular}

significativo ao nível de $5 \%$ de significância

n.s. não significativo ao nível de $5 \%$

\section{Análise Imediata}

\subsection{Materiais Voláteis}

Tabela 30. Resultados do teste de Dunnett para os materiais voláteis das amostras

\begin{tabular}{|c|c|c|}
\hline Amostra Referência & Amostra Contrastada & Contraste \\
\hline 6 & 5 & $24.71\left(^{*}\right)$ \\
\hline 6 & 8 & $20.18\left(^{*}\right)$ \\
\hline 6 & 15 & $19.75\left(^{*}\right)$ \\
\hline 6 & 21 & $17.60\left(^{*}\right)$ \\
\hline 6 & 19 & $17.35\left(^{*}\right)$ \\
\hline 6 & 14 & $14.77\left(^{*}\right)$ \\
\hline 6 & 1 & $14.17\left(^{*}\right)$ \\
\hline 6 & 2 & $13.57\left(^{*}\right)$ \\
\hline 6 & 17 & $13.52\left(^{*}\right)$ \\
\hline 6 & 20 & $12.18\left(^{*}\right)$ \\
\hline 6 & 24 & $11.98\left(^{*}\right)$ \\
\hline 6 & 3 & $11.67\left(^{*}\right)$ \\
\hline 6 & 12 & $10.54\left(^{*}\right)$ \\
\hline 6 & 7 & $10.24\left(^{*}\right)$ \\
\hline 6 & 25 & $8.98\left(^{*}\right)$ \\
\hline 6 & 10 & $7.67\left(^{*}\right)$ \\
\hline 6 & 9 & $7.49\left(^{*}\right)$ \\
\hline 6 & 16 & $6.98\left(^{*}\right)$ \\
\hline 6 & 4 & $5.93\left(^{*}\right)$ \\
\hline 6 & 23 & $5.73\left(^{*}\right)$ \\
\hline 6 & 18 & $\left.4.50{ }^{*}\right)$ \\
\hline 6 & 22 & $3.70\left(^{*}\right)$ \\
\hline
\end{tabular}




\begin{tabular}{ccc}
\hline 6 & 13 & $3.56(\mathrm{~ns})$ \\
6 & 11 & $3.21(\mathrm{~ns})$ \\
\hline
\end{tabular}

* significativo ao nível de $5 \%$ de significância

n.s. não significativo ao nivel de $5 \%$

\section{2. Cinzas}

Tabela 31. Resultados do teste de Dunnett para o teor de cinzas das amostras

\begin{tabular}{|c|c|c|}
\hline Amostra Referência & Amostra Contrastada & Contraste \\
\hline$\overline{15}$ & $\overline{11}$ & $2.27\left(^{\star}\right)$ \\
\hline 15 & 13 & $2.11\left(^{\star}\right)$ \\
\hline 15 & 24 & $2.02\left(^{*}\right)$ \\
\hline 15 & 22 & $1.96\left(^{*}\right)$ \\
\hline 15 & 12 & $1.70\left(^{*}\right)$ \\
\hline 15 & 25 & $1.68\left(^{*}\right)$ \\
\hline 15 & 9 & $1.49\left(^{*}\right)$ \\
\hline 15 & 14 & $1.34\left(^{*}\right)$ \\
\hline 15 & 6 & $1.28\left(^{*}\right)$ \\
\hline 15 & 18 & $1.13\left(^{*}\right)$ \\
\hline 15 & 2 & $1.13\left(^{*}\right)$ \\
\hline 15 & 10 & $1.11\left(^{\star}\right)$ \\
\hline 15 & 7 & $1.01\left(^{\star}\right)$ \\
\hline 15 & 20 & $1.01\left(^{*}\right)$ \\
\hline 15 & 8 & $0.99\left(^{*}\right)$ \\
\hline 15 & 1 & $0.97\left(^{*}\right)$ \\
\hline 15 & 16 & $0.92\left(^{*}\right)$ \\
\hline 15 & 5 & $0.91\left(^{*}\right)$ \\
\hline 15 & 4 & $0.83\left(^{\star}\right)$ \\
\hline 15 & 23 & $0.83\left(^{*}\right)$ \\
\hline 15 & 21 & $0.80\left(^{*}\right)$ \\
\hline 15 & 3 & $0.71\left(^{\star}\right)$ \\
\hline 15 & 17 & $0.46\left(^{*}\right)$ \\
\hline 15 & 19 & 0.33 (n.s.) \\
\hline
\end{tabular}

* significativo ao nível de $5 \%$ de significância

n.s. não significativo ao nivel de $5 \%$ 


\subsection{Carbono Fixo}

Tabela 32. Resultados do teste de Dunnett para o carbono fixo das amostras

\begin{tabular}{|c|c|c|}
\hline Amostra Referência & Amostra Contrastada & Contraste \\
\hline 6 & 11 & 2.53 (n.s.) \\
\hline 6 & 18 & 2.37 (n.s.) \\
\hline 6 & 22 & 2.35(n.s.) \\
\hline 6 & 13 & 2.34(n.s.) \\
\hline 6 & 23 & 1.44(n.s.) \\
\hline 6 & 4 & 1.24 (n.s.) \\
\hline 6 & 16 & 0.11 (n.s.) \\
\hline 6 & 14 & $-0.56\left(^{*}\right)$ \\
\hline 6 & 10 & $-0.77\left(^{*}\right)$ \\
\hline 6 & 9 & $-0.97\left(^{*}\right)$ \\
\hline 6 & 25 & $-2.65\left(^{\star}\right)$ \\
\hline 6 & 7 & $-3.26\left(^{\star}\right)$ \\
\hline 6 & 12 & $-4.22\left(^{\star}\right)$ \\
\hline 6 & 3 & $-4.36\left(^{*}\right)$ \\
\hline 6 & 20 & $-5.17\left(^{\star}\right)$ \\
\hline 6 & 17 & $-5.97\left(^{*}\right)$ \\
\hline 6 & 24 & $-5.99\left(^{*}\right)$ \\
\hline 6 & 2 & $-6.69\left(^{*}\right)$ \\
\hline 6 & 1 & $-7.13\left(^{\star}\right)$ \\
\hline 6 & 19 & $-9.67\left(^{*}\right)$ \\
\hline 6 & 21 & $-10.39\left(^{*}\right)$ \\
\hline 6 & 15 & $-11.74\left(^{*}\right)$ \\
\hline 6 & 8 & $-13.17\left(^{*}\right)$ \\
\hline 6 & 5 & $-17.61\left(^{\star}\right)$ \\
\hline
\end{tabular}

* significativo ao nível de $5 \%$ de significância

n.s. não significativo ao nivel de $5 \%$

\subsection{Umidade}

Tabela 33. Resultados do teste de Dunnett para a umidade das amostras

\begin{tabular}{|c|c|c|}
\hline Amostra Referência & Amostra Contrastada & Contraste \\
\hline 5 & 6 & $5.33\left(^{*}\right)$ \\
\hline 5 & 11 & $3.49\left(^{*}\right)$ \\
\hline 5 & 22 & $3.46\left(^{*}\right)$ \\
\hline 5 & 18 & $3.16\left(^{*}\right)$ \\
\hline 5 & 13 & $2.64\left(^{*}\right)$ \\
\hline 5 & 23 & $2.48\left(^{*}\right)$ \\
\hline 5 & 17 & $2.04\left(^{*}\right)$ \\
\hline 5 & 19 & $1.71\left(^{*}\right)$ \\
\hline 5 & 4 & $1.59\left(^{*}\right)$ \\
\hline 5 & 25 & $1.39\left(^{*}\right)$ \\
\hline 5 & 15 & $1.39\left(^{*}\right)$ \\
\hline 5 & 3 & $\left.1.31{ }^{*}\right)$ \\
\hline 5 & 24 & $1.30\left(^{*}\right)$ \\
\hline
\end{tabular}




\begin{tabular}{ccc}
5 & 20 & $1.28\left(^{*}\right)$ \\
5 & 10 & $1.17\left(^{*}\right)$ \\
5 & 14 & $1.14\left(^{*}\right)$ \\
5 & 9 & $1.08\left(^{*}\right)$ \\
5 & 21 & $1.0\left(^{\star}\right)$ \\
5 & 7 & $0.85\left(^{*}\right)$ \\
5 & 16 & 0.75 (n.s.) \\
5 & 2 & 0.74 (n.s.) \\
5 & 12 & 0.72 (n.s.) \\
5 & 1 & 0.28 (n.s.) \\
5 & 8 & 0.03 (n.s.) \\
\hline
\end{tabular}

ॠsignificativo ao nível de $5 \%$ de significância

n.s. não significativo ao nível de $5 \%$

\section{Densidade}

\subsection{Densidade à granel}

Tabela 34. Resultados do teste de Dunnett para a densidade à granel das amostras

\begin{tabular}{|c|c|c|}
\hline Amostra Referência & Amostra Contrastada & Contraste \\
\hline 8 & 21 & -7.11 (n.s.) \\
\hline 8 & 15 & -12.52 (n.s.) \\
\hline 8 & 23 & -24.39 (n.s.) \\
\hline 8 & 7 & $-35.93\left(^{*}\right)$ \\
\hline 8 & 4 & $-36.69\left(^{*}\right)$ \\
\hline 8 & 3 & $-38.06\left(^{*}\right)$ \\
\hline 8 & 18 & $-38.14\left(^{*}\right)$ \\
\hline 8 & 19 & $-42.14\left(^{*}\right)$ \\
\hline 8 & 12 & $-43.70\left(^{*}\right)$ \\
\hline 8 & 16 & $-44.55\left(^{*}\right)$ \\
\hline 8 & 14 & $-47.16\left(^{*}\right)$ \\
\hline 8 & 13 & $-50.46\left({ }^{*}\right)$ \\
\hline 8 & 24 & $-51.74\left(^{*}\right)$ \\
\hline 8 & 11 & $-68.53\left(^{*}\right)$ \\
\hline 8 & 6 & $-73.23\left(^{*}\right)$ \\
\hline 8 & 17 & $-78.99\left(^{*}\right)$ \\
\hline 8 & 10 & $-80.80\left(^{*}\right)$ \\
\hline 8 & 22 & $-81.12\left(^{*}\right)$ \\
\hline 8 & 5 & $-82.23\left(^{*}\right)$ \\
\hline 8 & 20 & $-90.21\left(^{*}\right)$ \\
\hline 8 & 9 & $-101.86\left(^{*}\right)$ \\
\hline 8 & 1 & $-113.45\left(^{\star}\right)$ \\
\hline 8 & 2 & $-115.98\left(^{\star}\right)$ \\
\hline 8 & 25 & $-117.33\left(^{*}\right)$ \\
\hline
\end{tabular}

* significativo ao nível de $5 \%$ de significância

n.s. não significativo ao nível de $5 \%$ 


\subsection{Densidade Aparente}

Tabela 35. Resultados do teste de Dunnett para a densidade aparente das amostras

\begin{tabular}{|c|c|c|}
\hline Amostra Referência & Amostra Contrastada & Contraste \\
\hline 15 & 3 & -0.01 (n.s.) \\
\hline 15 & 17 & -0.07 (n.s.) \\
\hline 15 & 18 & -0.08 (n.s.) \\
\hline 15 & 8 & -0.08 (n.s.) \\
\hline 15 & 24 & -0.08 (n.s.) \\
\hline 15 & 4 & -0.10 (n.s.) \\
\hline 15 & 13 & $-0.10\left(^{*}\right)$ \\
\hline 15 & 7 & $-0.10\left(^{\star}\right)$ \\
\hline 15 & 21 & $-0.11\left(^{\star}\right)$ \\
\hline 15 & 16 & $-0.11\left(^{*}\right)$ \\
\hline 15 & 5 & $-0.13\left(^{\star}\right)$ \\
\hline 15 & 23 & $-0.15\left(^{\star}\right)$ \\
\hline 15 & 19 & $-0.18\left(^{*}\right)$ \\
\hline 15 & 12 & $-0.19\left(^{\star}\right)$ \\
\hline 15 & 10 & $-0.20\left(^{\star}\right)$ \\
\hline 15 & 6 & $-0.21\left(^{\star}\right)$ \\
\hline 15 & 1 & $-0.21\left(^{\star}\right)$ \\
\hline 15 & 11 & $-0.22\left(^{*}\right)$ \\
\hline 15 & 9 & $-0.23\left(^{*}\right)$ \\
\hline 15 & 14 & $-0.24\left(^{\star}\right)$ \\
\hline 15 & 2 & $-0,24\left(^{*}\right)$ \\
\hline 15 & 20 & $-0.25\left(^{*}\right)$ \\
\hline 15 & 25 & $-0.25\left(^{\star}\right)$ \\
\hline 15 & 22 & $-0.26\left(^{\star}\right)$ \\
\hline
\end{tabular}

* significativo ao nível de $5 \%$ de significância

n.s. não significativo ao nível de $5 \%$ 


\section{APÊNDICE 4}

\section{CONTRIBUIÇÕES PARA A ELABORAÇÀO DE UM PLANEJAMENTO MUNICIPAL PARA PEDRA BELA - ESTADO DE SÃO PAULO}

O presente estudo objetivou a caracterização social, ambiental e tecnológica do carvão vegetal produzido no Município de Pedra Bela. O carvão vegetal foi o foco desse estudo, todavia existe uma série de outras alternativas que poderiam ser implantadas no Município.

Os resultados gerados nesse trabalho poderão subsidiar um estudo mais aprofundado das alternativas econômicas mais viáveis, em função das condições atuais de uso do solo e de potencialidades naturais do Município.

São sugeridas à seguir algumas proposições e apontamentos que visam contribuir para a elaboração de um planejamento Municipal, todavia, cada um deles exigiria um aprofundado estudo de viabilidade.

\section{SUSTENTABILIDADE DA ATIVIDADE DE CARVOEJAMENTO}

O presente estudo demonstrou que para a continuidade da atividade de carvoejamento no Município há necessidade de se investir na matéria-prima, sob dois aspectos:

a) aumento de produtividade: as florestas encontram-se com uma produtividade baixa (em torno de $15 \mathrm{~m}^{3} /$ ha/ano), sendo escassas as práticas de manejo e reforma das florestas existentes.

b) aumento das áreas de reflorestamento: para garantir o funcionamento de toda a capacidade de produção de carvão vegetal instalada no Município é necessário a expansão das áreas de cultivo de espécies de Eucalyptus sp. Considerando-se, por exemplo, uma floresta com produção média de $30 \mathrm{~m}^{3} / \mathrm{ha} / \mathrm{ano}$, para atender a capacidade instalada 
são necessários atualmente, cerca de 122 mil metros cúbicos de madeira por ano. Isso significa que é preciso se utilizar $4.000 \mathrm{ha} / \mathrm{ano}$. Considerando-se um ciclo de cinco anos (idade suficiente para a produção do carvão vegetal) é necessário que se garanta uma área total de plantio de cerca de 20.000ha para a sustentabilidade da atividade de carvoejamento no Município. Atualmente apenas 2.170 são destinados ao reflorestamento, ou seja, mesmo com o dobro da produtividade (de 15 para $30 \mathrm{~m}^{3} / \mathrm{ha} / \mathrm{ano}$ ) o Município tem capacidade para atender somente $10 \%$ da demanda de madeira.

\section{IMPLANTAÇÃO DE SISTEMA AGROSILVIPASTORIL}

Conforme os dados da Secretaria de Agricultura e Abastecimento do Estado de São Paulo - Projeto LUPA. (1996), cerca de 63\% da área rural do Município de Pedra Bela vem sendo destinadas a pastagens.

Detectou-se através do presente estudo, que a escassez da madeira será um grande entrave para a continuidade da atividade de carvoejamento no Município. Desta forma, a adoção do sistema agrosilvipatoril seria uma alternativa para a manutenção da pecuária e otimização do uso da área, intercalando-a com o plantio de espécies Eucalyptus sp. propícias à região e recomendadas à produção de carvão vegetal.

O sistema agrosilvipastoril permite a consorciação de diferentes espécies. Em Minas Gerais, por exemplo, existem consorciações com Eucalyptus sp, com consórcios seqüenciais de Eucalyptus e seus hibridos com cultivos anuais nas entrelinhas, nos primeiros anos de estabelecimento da floresta, seguidos posteriormente da semeadura de forrageiras perenes para engorda de gado de corte. Tais alternativas constituem-se num potencial para amortizar os custos iniciais de implantação e manutenção das plantações florestais, permitir fluxo de caixa constante ao longo do periodo de maturação 
da floresta, além de fornecer rendas complementares (Oliveira e Macedo, 1996).

A utilização de sistemas consorciados de florestas com culturas agrícolas e, ou pastagens bem planejadas reduz consideravelmente os custos de implantação e manutenção das árvores, aumenta a produtividade do local e minimiza a erosão do solo e outros impactos negativos ao meio ambiente (Passos, 1996).

Para sustentar a atividade pecuária nos locais de reflorestamento com Eucalyptus $s p$. recomenda-se interplantar forrageiras entre as árvores, pois o sub-bosque, em geral, apresenta baixo valor forrageiro (Dubé et al., 2000).

No Município de Torrinha/SP, por exemplo, vem sendo desenvolvido uma criação extensiva de gado de corte em áreas florestadas com eucaliptos, tecnicamente manejados para produção de folhas, matéria-prima para a extração de óleo essencial. Para a agricultura sustentável pode-se destacar algumas vantagens sobre uma pecuária de corte extensiva, tais como o plantio de eucalipto no pasto como elemento de auxílio no controle da erosão; o eucalipto como elemento indutor de enriquecimento da fauna e da biodiversidade; o retorno de parte dos nutrientes retirados, tanto pela adubação natural feita pelo gado durante o pastoreio, como pela reincorporação do bagaço resultante da extração do óleo; consorciamento indicado para pequenas áreas e com baixa aptidão ao uso agrícola, seja por restrição de fertilidade de solo ou por declividade inadequada ao cultivo mecanizado, características usualmente presentes nas áreas onde predominam propriedade familiares. (Toledo, 2002).

\subsection{Sugestões de espécies de Eucalyptus sp. para o Município de Pedra} Bela.

Seguem algumas sugestões de espécies de Eucapytus sp. apropriadas para produção de carvão vegetal no Município de Pedra Bela: 
Tabela 36. Espécies de Eucalyptus utilizadas para produção de carvão vegetal, aos cinco anos.

\begin{tabular}{lcc}
\hline \multicolumn{1}{c}{ Espécie } & $\begin{array}{c}\text { Densidade básica da madeira } \\
\left(\mathrm{g} / \mathrm{cm}^{3}\right)\end{array}$ & $\begin{array}{c}\text { Densidade aparente do carvão } \\
\left(\mathrm{g} / \mathrm{cm}^{3}\right)\end{array}$ \\
\hline E. camaldulensis & 0,435 & 0,272 \\
E.citriodora & 0,536 & 0,321 \\
E. saligna & 0,403 & 0,233 \\
E. grandis & 0,406 & 0,231 \\
E. urophylla & 0,457 & 0,271 \\
\hline
\end{tabular}

Fonte: Manual CETEC, 1980

Caracteristicas da madeira:

- apresentar densidade entre 0,4 a $0,6 \mathrm{~g} / \mathrm{cm}^{3}$;

- ser adaptadas para regiões de altitude, como é o caso de Pedra Bela;

- apresentar características pertinentes à produção de carvão vegetal.

Todavia, é interessante apontar que o relevo ondulado existente na região e a legislação florestal devem ser consideradas nas proposições do planejamento municipal. 


\section{PRODUTOS ORGÂNICOS}

A produção orgânica pode ser outra fonte alternativa de renda, inclusive com a utilização de subprodutos do carvão vegetal, tais como o licor pirolenhoso e o pó de carvão. O município localiza-se próximo à centros urbanos, como São Paulo e Campinas, o que pode facilitar o escoamento dos produtos.

\section{CRIAÇÃO DE UM SISTEMA PILOTO PARA O BENEFICIAMENTO DE CARVÃO VEGETAL}

O beneficiamento do carvão vegetal pode ser uma maneira dos empreendimentos de carvão vegetal agregarem valor ao produto. Foi detectado que somente $14 \%$ dos empreendimentos de Pedra Bela produzem e distribuem carvão.

\section{a) Criação de cooperativa ou associação}

A criação de cooperativa ou associação pode ser uma maneira de diminuir gastos de produção e de aquisição de equipamentos. A criação de uma central de beneficiamento, pode ser uma alternativa onde todos os produtores passariam a atuar na formalidade e devidamente cadastrados, podendo embalar seu carvão. A participação de cada empreendedor poderá ocorrer a partir da quantidade de carvão produzida e dos serviços prestados à instituição. 


\section{b) Criação de marca própria}

A criação de uma marca própria, por exemplo, "Carvão Pedra Bela", que agregue pequenos produtores, poderá favorecer a comercialização e a oferta contínua de carvão vegetal ao mercado consumidor.

\section{UTILIZAÇÃO DE SUBPRODUTOS}

Os subprodutos do carvão vegetal podem se tornar fontes de renda, por apresentarem, muitas vezes, um valor até superior ao próprio carvão vegetal. Todavia, o mercado para tais subprodutos é ainda pouco explorado e instável. Para isso, há necessidade de um estudo de mercado mais aprofundado que possa garantir o escoamento desses produtos, para que os mesmos não venham a se tornar apenas um resíduo acumulado nas propriedades. Dentre as possibilidades de utilização dos subprodutos citam-se:

b) Extração do licor pirolenhoso: utilizado na indústria farmacêutica e cosmética. Pode ser aplicada também na agricultura orgânica, para a aceleração da compostagem;

c) Utilização de finos de carvão vegetal: estudos vem sendo realizados para sua utilização como complemento para a alimentação de aves e bovinos, como forma de diminuição do colesterol. 